Cochrane Database of Systematic Reviews

\title{
Acupuncture for acute stroke (Review)
}

Xu M, Li D, Zhang S

Xu M, Li D, Zhang S.

Acupuncture for acute stroke.

Cochrane Database of Systematic Reviews 2018, Issue 3. Art. No.: CD003317.

DOI: 10.1002/14651858.CD003317.pub3.

www.cochranelibrary.com 
TABLE OF CONTENTS

HEADER 1

ABSTRACT

PLAIN LANGUAGE SUMMARY

SUMMARY OF FINDINGS

BACKGROUND

OBJECTIVES

METHODS

RESULTS

Figure 1.

Figure 2.

DISCUSSION

Figure 3.

Figure 4.

AUTHORS' CONCLUSIONS

ACKNOWLEDGEMENTS

REFERENCES

CHARACTERISTICS OF STUDIES

DATA AND ANALYSES

Analysis 1.1. Comparison 1 Acupuncture versus control, Outcome 1 Death or dependency at end of follow-up. .....................

Analysis 1.2. Comparison 1 Acupuncture versus control, Outcome 2 Death or dependency at end of follow-up (>3 months). ...

Analysis 1.3. Comparison 1 Acupuncture versus control, Outcome 3 Death or institutional care at end of follow-up. ................

Analysis 1.4. Comparison 1 Acupuncture versus control, Outcome 4 Change in global neurological deficit score at end of treatment period.

Analysis 1.5. Comparison 1 Acupuncture versus control, Outcome 5 Motor function at end of acupuncture treatment period. ..

Analysis 1.6. Comparison 1 Acupuncture versus control, Outcome 6 Motor function at end of follow-up (> 3 months). .............

Analysis 1.7. Comparison 1 Acupuncture versus control, Outcome 7 Death within first 2 weeks.

Analysis 1.8. Comparison 1 Acupuncture versus control, Outcome 8 Death during whole follow-up period.

Analysis 1.9. Comparison 1 Acupuncture versus control, Outcome 9 Adverse events during treatment period.

Analysis 2.1. Comparison 2 Ischemic stroke versus hemorrhagic stroke, Outcome 1 Death or dependency at end of follow-up. . APPENDICES

WHAT'S NEW

CONTRIBUTIONS OF AUTHORS

DECLARATIONS OF INTEREST

SOURCES OF SUPPORT

DIFFERENCES BETWEEN PROTOCOL AND REVIEW

INDEX TERMS 
[Intervention Review]

\title{
Acupuncture for acute stroke
}

\author{
Mangmang $\mathrm{Xu}^{1}$, Dan $\mathrm{Li}^{2}$, Shihong Zhang1
}

1Department of Neurology, West China Hospital, Sichuan University, Chengdu, China. 2Department of Neurology, Henan Provincial People's Hospital of Zhengzhou University, Zhengzhou, China

Contact address: Shihong Zhang, Department of Neurology, West China Hospital, Sichuan University, Chengdu, 610041, China. zsh9@hotmail.com.

Editorial group: Cochrane Stroke Group.

Publication status and date: New search for studies and content updated (conclusions changed), published in Issue 3, 2018.

Citation: Xu M, Li D, Zhang S. Acupuncture for acute stroke. Cochrane Database of Systematic Reviews 2018, Issue 3. Art. No.: CD003317. DOI: 10.1002/14651858.CD003317.pub3.

Copyright @ 2018 The Cochrane Collaboration. Published by John Wiley \& Sons, Ltd.

\section{A B S T R A C T}

\section{Background}

Sensory stimulation via acupuncture has been reported to alter activities of numerous neural systems by activating multiple efferent pathways. Acupuncture, one of the main physical therapies in Traditional Chinese Medicine, has been widely used to treat patients with stroke for over hundreds of years. This is the first update of the Cochrane Review originally published in 2005.

\section{Objectives}

To assess whether acupuncture could reduce the proportion of people with death or dependency, while improving quality of life, after acute ischemic or hemorrhagic stroke.

\section{Search methods}

We searched the Cochrane Stroke Group trials register (last searched on February 2, 2017), the Cochrane Central Register of Controlled Trials Ovid (CENTRAL Ovid; 2017, Issue 2) in the Cochrane Library, MEDLINE Ovid (1946 to February 2017), Embase Ovid (1974 to February 2017), the Cumulative Index to Nursing and Allied Health Literature (CINAHL) EBSCO (1982 to February 2017), the Allied and Complementary Medicine Database (AMED; 1985 to February 2017), China Academic Journal Network Publishing Database (1998 to February 2017), and the VIP database (VIP Chinese Science Journal Evaluation Reports; 1989 to February 2017). We also identified relevant trials in the Chinese Clinical Trial Registry (last searched on Feburuary 20, 2017), the World Health Organization (WHO) International Clinical Trials Registry Platform (last searched on April 30, 2017), and Clinicaltrials.gov (last searched on April 30, 2017). In addition, we handsearched the reference lists of systematic reviews and relevant clinical trials.

\section{Selection criteria}

We sought randomized clinical trials (RCTs) of acupuncture started within 30 days from stroke onset compared with placebo or sham acupuncture or open control (no placebo) in people with acute ischemic or hemorrhagic stroke, or both. Needling into the skin was required for acupuncture. Comparisons were made versus (1) all controls (open control or sham acupuncture), and (2) sham acupuncture controls.

\section{Data collection and analysis}

Two review authors applied the inclusion criteria, assessed trial quality and risk of bias, and extracted data independently. We contacted study authors to ask for missing data. We assessed the quality of the evidence by using the GRADE approach. We defined the primary outcome as death or dependency at the end of follow-up .

\section{Main results}

We included in this updated review 33 RCTs with 3946 participants. Twenty new trials with 2780 participants had been completed since the previous review. Outcome data were available for up to 22 trials (2865 participants) that compared acupuncture with any control 
(open control or sham acupuncture) but for only six trials (668 participants) that compared acupuncture with sham acupuncture control. We downgraded the evidence to low or very low quality because of risk of bias in included studies, inconsistency in the acupuncture intervention and outcome measures, and imprecision in effect estimates.

When compared with any control (11 trials with 1582 participants), findings of lower odds of death or dependency at the end of followup and over the long term ( $\geq$ three months) in the acupuncture group were uncertain (odds ratio $[\mathrm{OR}] 0.61,95 \%$ confidence interval $[\mathrm{Cl}]$ 0.46 to 0.79 ; very low-quality evidence; and $\mathrm{OR} 0.67,95 \% \mathrm{Cl} 0.53$ to 0.85 ; eight trials with 1436 participants; very low-quality evidence, respectively) and were not confirmed by trials comparing acupuncture with sham acupuncture (OR $0.71,95 \% \mathrm{Cl} 0.43$ to 1.18 ; low-quality evidence; and $\mathrm{OR} 0.67,95 \% \mathrm{Cl} 0.40$ to 1.12 ; low-quality evidence, respectively).

In trials comparing acupuncture with any control, findings that acupuncture was associated with increases in the global neurological deficit score and in the motor function score were uncertain (standardized mean difference [SMD] 0.84, 95\% $\mathrm{Cl} 0.36$ to $1.32 ; 12$ trials with 1086 participants; very low-quality evidence; and SMD 1.08, 95\% CI 0.45 to 1.71; 11 trials with 895 participants; very low-quality evidence). These findings were not confirmed in trials comparing acupuncture with sham acupuncture (SMD $0.01,95 \% \mathrm{Cl}-0.55$ to 0.57 ; low-quality evidence; and SMD $0.10,95 \% \mathrm{Cl}-0.38$ to 0.17 ; low-quality evidence, respectively).

Trials comparing acupuncture with any control have reported little or no difference in death or institutional care at the end of follow-up (OR $0.78,95 \% \mathrm{Cl} 0.54$ to 1.12; five trials with 1120 participants; low-quality evidence), death within the first two weeks (OR $0.91,95 \% \mathrm{Cl}$ 0.33 to 2.55 ; 18 trials with 1612 participants; low-quality evidence), or death at the end of follow-up (OR $1.08,95 \% \mathrm{Cl} 0.74$ to $1.58 ; 22$ trials with 2865 participants; low-quality evidence).

The incidence of adverse events (eg, pain, dizziness, faint) in the acupuncture arms of open and sham control trials was $6.2 \%$ (64/1037 participants), and $1.4 \%$ of these (14/1037 participants) discontinued acupuncture. When acupuncture was compared with sham acupuncture, findings for adverse events were uncertain (OR $0.58,95 \% \mathrm{Cl} 0.29$ to 1.16 ; five trials with 576 participants; low-quality evidence).

\section{Authors' conclusions}

This updated review indicates that apparently improved outcomes with acupuncture in acute stroke are confounded by the risk of bias related to use of open controls. Adverse events related to acupuncture were reported to be minor and usually did not result in stopping treatment. Future studies are needed to confirm or refute any effects of acupuncture in acute stroke. Trials should clearly report the method of randomization, concealment of allocation, and whether blinding of participants, personnel, and outcome assessors was achieved, while paying close attention to the effects of acupuncture on long-term functional outcomes.

\section{PLAIN LANGUAGE SUMMARY}

\section{Acupuncture for acute stroke}

\section{Review question}

To assess the effects and safety of acupuncture for rehabilitating people after stroke caused by blood clots or bleeding in the brain.

\section{Background}

Stroke is a devastating disease with high morbidity and mortality. Acupuncture, one of the main physical therapies in Traditional Chinese Medicine, has been widely used to treat stroke for over hundreds of years in China, but evidence of its effectiveness in stroke rehabilitation is inconsistent.

\section{Study characteristics}

We searched electronic databases and the Chinese Clinical Trial Registry up to February 2017, and two clinical trials platforms (WHO International Clinical Trials Registry Platform and Clinicaltrials.gov) up to April 2017. We included in this review 33 randomized clinical trials (RCTs) with 3946 participants. Of these, results were available for up to 22 trials (2865 participants) that compared acupuncture with any control but for only six trials (668 participants) that compared acupuncture with a sham acupuncture procedure.

\section{Key results}

The effects of acupuncture in reducing death or dependency or improving neurological and movement scores at the end of follow-up, as seen in trials comparing acupuncture with any control, were not seen in trials comparing acupuncture with the more reliable control of sham acupuncture. Adverse events such as pain, dizziness, and faint were reported in $6.2 \%$ (64/1037) of participants, and $1.4 \%$ (14) of these had to discontinue acupuncture.

\section{Quality of the evidence}

The quality of the evidence was low or very low owing to risk of bias in the included studies and variation in the type and duration of acupuncture. Additional larger reliable research trials are required for enhanced confidence in the effects of acupuncture for acute stroke. 


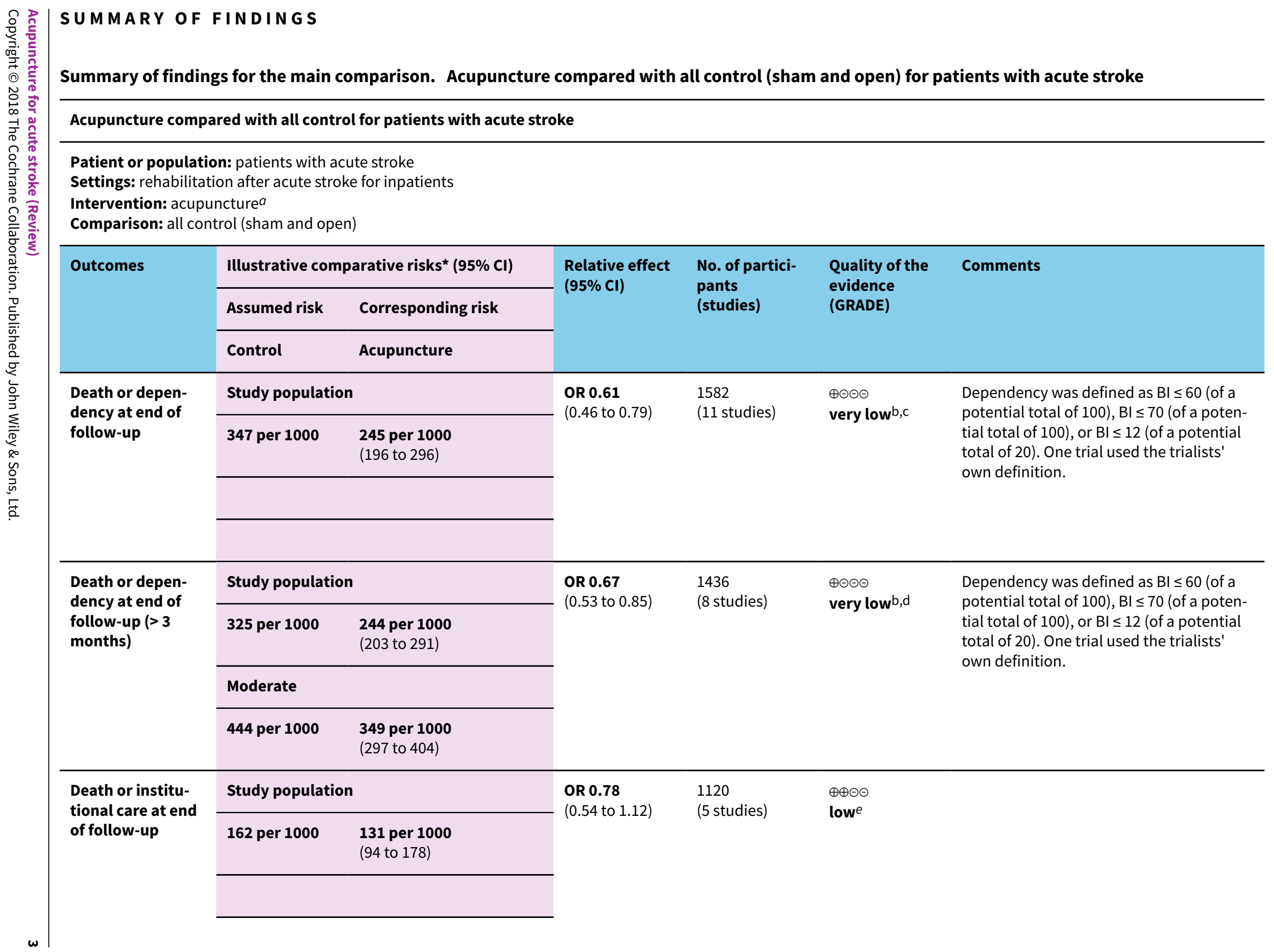




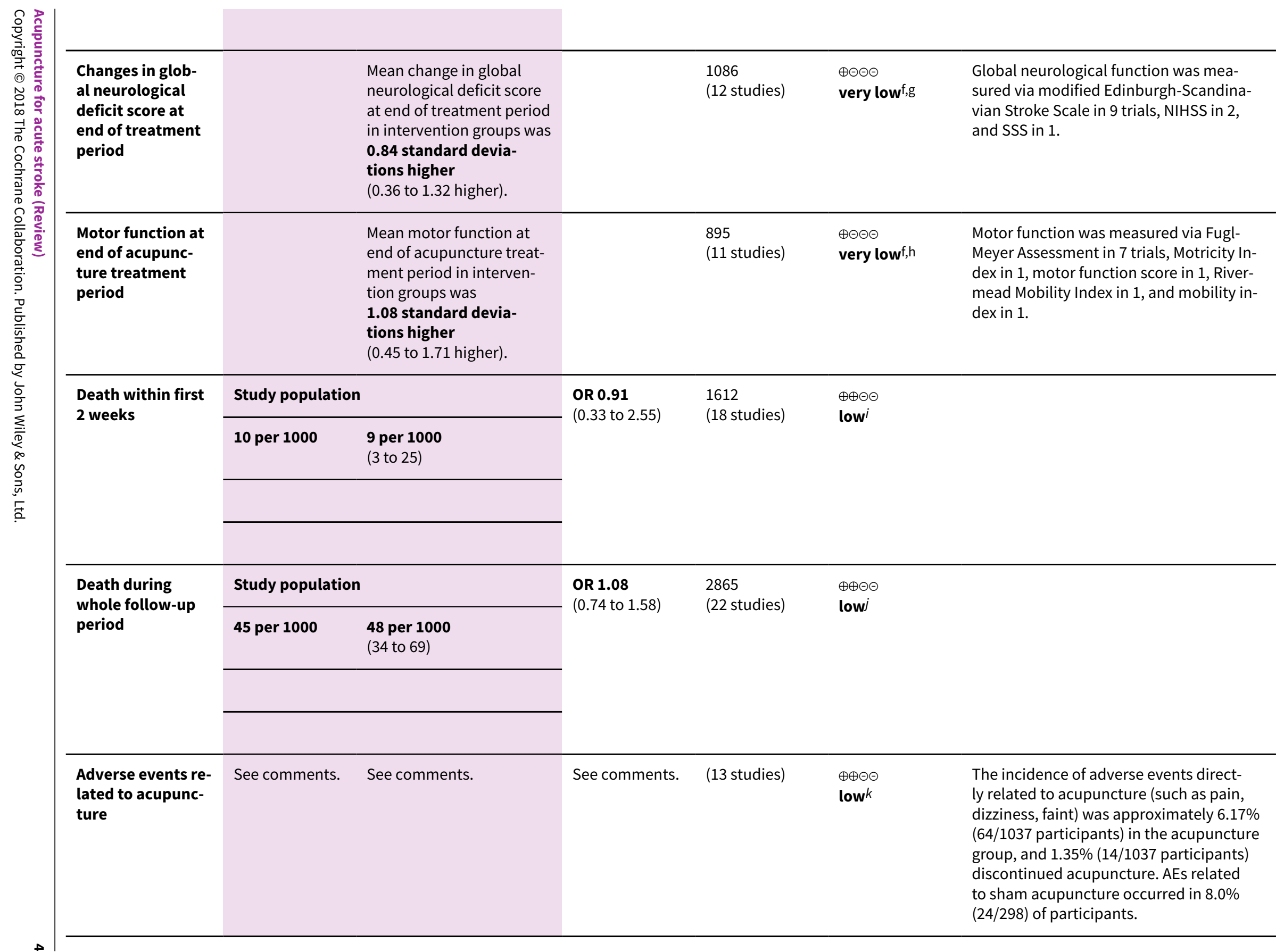


*The basis for the assumed risk (eg, the median control group risk across studies) is provided in footnotes. The corresponding risk (and its $95 \%$ confidence interval) is based on the assumed risk in the comparison group and the relative effect of the intervention (and its $95 \% \mathrm{Cl}$ ).

AEs: adverse events; BI: Barthel Index; Cl: confidence interval; NIHSS: National Institute of Health Stroke Scale; OR: odds ratio; RCTs: randomized controlled trials; SSS: Scandinavian Stroke Scale.

GRADE Working Group grades of evidence.

High quality: Further research is very unlikely to change our confidence in the estimate of effect.

Moderate quality: Further research is likely to have an important impact on our confidence in the estimate of effect and may change the estimate.

Low quality: Further research is very likely to have an important impact on our confidence in the estimate of effect and is likely to change the estimate.

Very low quality: We are very uncertain about the estimate.

a f the 33 included RCTs, the acupuncture treatment type and period were heterogeneous. The acupuncture treatment period ranged from one to three months. The acupoints varied across trials. The needling sensation could be provoked by manual stimulation or electrical stimulation.

$b$ Downgraded one level for serious inconsistency: variation in the definition of dependency and acupuncture treatment type and duration.

cDowngraded two levels for very serious risk of bias: Among the 11 included trials, eight had risk of performance bias and seven had risk of detection bias; the result was not consistent with the sensitivity analysis using only sham controls.

$d$ Downgraded two levels for very serious risk of bias: Among the eight included trials, six had risk of performance bias and four had risk of detection bias; the result was not consistent with the sensitivity analysis using only sham controls.

eDowngraded two levels for very serious risk of bias: Among the five included trials, four had risk of performance bias; the result was not consistent with the sensitivity analysis using only sham controls.

fDowngraded two levels for very serious inconsistency: considerable statistical heterogeneity $(12>50 \%)$ and variation in acupuncture treatment type and duration.

gDowngraded two levels for very serious risk of bias: Among the 13 included trials, at least eight trials had risk of allocation bias, performance bias, or detection bias; the result was not consistent with the sensitivity analysis using only sham controls.

hDowngraded two levels for very serious risk of bias: Among the 11 included trials, at least six had risk of allocation bias, performance bias, or detection bias; the result was not consistent with the sensitivity analysis using only sham controls.

iDowngraded two levels for very serious risk of bias: Among the 18 included trials, at least 10 trials had risk of allocation bias, performance bias, or detection bias; the result was not consistent with the sensitivity analysis using only sham controls.

jDowngraded two levels for very serious risk of bias: Among the 22 included trials, at least 11 trials had risk of allocation bias, performance bias, or detection bias; the result was not consistent with the sensitivity analysis using only sham controls.

kDowngraded two levels for very serious inconsistency: variation between trials in reporting of adverse events and in acupuncture treatment type and duration.

Summary of findings 2 . Acupuncture compared with sham control for patients with acute stroke

\section{Acupuncture compared with sham control for patients with acute stroke}

Patient or population: patients with acute stroke

Settings: rehabilitation after acute stroke for inpatients

Intervention: acupuncture

Comparison: sham control

\section{No. of partici-}

pants

(studies)

Quality of the Comments
evidence

evidence

(GRADE) 


\begin{tabular}{|c|c|c|c|c|c|c|c|}
\hline & Assumed risk & Corresponding risk & & & & & \\
\hline & Control & Acupuncture & & & & & \\
\hline \multirow{2}{*}{$\begin{array}{l}\text { Death or dependency at } \\
\text { end of follow-up }\end{array}$} & \multicolumn{2}{|c|}{ Study population } & \multirow{2}{*}{$\begin{array}{l}\text { OR } 0.71 \\
\text { (0.43 to } 1.18)\end{array}$} & \multirow{2}{*}{$\begin{array}{l}262 \\
\text { (4 studies) }\end{array}$} & \multirow{2}{*}{$\begin{array}{l}\oplus \oplus \ominus \ominus \\
\text { low }^{2,3}\end{array}$} & & $\underline{2}$ \\
\hline & 464 per 1000 & $\begin{array}{l}\mathbf{3 8 4} \text { per } \mathbf{1 0 0 0} \\
\text { (264 to } 404)\end{array}$ & & & & & $<\overrightarrow{0}$ \\
\hline \multirow{2}{*}{$\begin{array}{l}\text { Death or dependency } \\
\text { at end of follow-up (>3 } \\
\text { months) }\end{array}$} & \multicolumn{2}{|c|}{ Study population } & \multirow{2}{*}{$\begin{array}{l}\text { OR } 0.67 \\
(0.40 \text { to } 1.12)\end{array}$} & \multirow{2}{*}{$\begin{array}{l}244 \\
\text { (3 studies) }\end{array}$} & \multirow{2}{*}{$\begin{array}{l}\oplus \oplus \ominus \ominus \\
\text { low }^{2,4}\end{array}$} & & 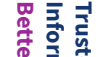 \\
\hline & 476 per 1000 & $\begin{array}{l}\mathbf{3 7 6} \text { per } \mathbf{1 0 0 0} \\
(256 \text { to } 496)\end{array}$ & & & & & 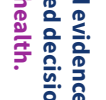 \\
\hline \multirow{2}{*}{$\begin{array}{l}\text { Death or institutional care } \\
\text { at end of follow-up }\end{array}$} & \multicolumn{2}{|c|}{ Study population } & \multirow{2}{*}{$\begin{array}{l}\text { OR } 0.47 \\
(0.23 \text { to } 0.96)\end{array}$} & \multirow{2}{*}{$\begin{array}{l}145 \\
\text { (2 studies) }\end{array}$} & \multirow{2}{*}{$\begin{array}{l}\oplus \oplus \ominus \ominus \\
\text { low }^{2,5}\end{array}$} & & \\
\hline & 456 per 1000 & $\begin{array}{l}\mathbf{2 8 6} \text { per } \mathbf{1 0 0 0} \\
(126 \text { to } 476)\end{array}$ & & & & & \\
\hline $\begin{array}{l}\text { Changes in global neuro- } \\
\text { logical deficit score at end } \\
\text { of treatment period }\end{array}$ & & $\begin{array}{l}\text { Mean change in global neurological deficit } \\
\text { score at end of treatment period in inter- } \\
\text { vention groups was } \\
\mathbf{0 . 0 1} \text { standard deviations higher } \\
\text { ( } 0.55 \text { lower to } 0.57 \text { higher). }\end{array}$ & & $\begin{array}{l}53 \\
\text { (1 studies) }\end{array}$ & $\begin{array}{l}\oplus \oplus \odot \ominus \\
\mathbf{l o w}^{6}\end{array}$ & & \\
\hline $\begin{array}{l}\text { Motor function at end of } \\
\text { acupuncture treatment } \\
\text { period }\end{array}$ & & $\begin{array}{l}\text { Mean motor function at end of acupuncture } \\
\text { treatment period in intervention groups } \\
\text { was } \\
\mathbf{0 . 1 0} \text { standard deviations lower } \\
\text { ( } 0.38 \text { lower to } 0.17 \text { higher). }\end{array}$ & & $\begin{array}{l}202 \\
\text { (3 studies) }\end{array}$ & $\begin{array}{l}\oplus \oplus \ominus \ominus \\
\text { low }^{2,7}\end{array}$ & & \\
\hline \multirow[t]{2}{*}{ Death within first 2 weeks } & \multicolumn{2}{|c|}{ Study population } & \multirow{2}{*}{$\begin{array}{l}\text { OR } 1.20 \\
(0.27 \text { to } 5.26)\end{array}$} & \multirow{2}{*}{$\begin{array}{l}378 \\
\text { (5 studies) }\end{array}$} & \multirow{2}{*}{$\begin{array}{l}\oplus \oplus \odot \odot \\
\text { low } 2,8\end{array}$} & & \\
\hline & 15 per 1000 & $\begin{array}{l}4 \text { per } 1000 \\
(0 \text { to } 45)\end{array}$ & & & & & 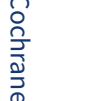 \\
\hline \multirow{2}{*}{$\begin{array}{l}\text { Death during whole fol- } \\
\text { low-up period }\end{array}$} & \multicolumn{2}{|c|}{ Study population } & \multirow{2}{*}{$\begin{array}{l}\text { OR } 0.90 \\
(0.47 \text { to } 1.72)\end{array}$} & \multirow{2}{*}{$\begin{array}{l}668 \\
\text { (6 studies) }\end{array}$} & \multirow{2}{*}{$\begin{array}{l}\oplus \oplus \odot \odot \\
\text { low } 2,9\end{array}$} & & 章 \\
\hline & 79 per 1000 & $\begin{array}{l}79 \text { per } 1000 \\
(59 \text { to } 99)\end{array}$ & & & & & 竞 \\
\hline $\begin{array}{l}\text { Adverse events related to } \\
\text { acupuncture }\end{array}$ & See comments. & See comments. & $\begin{array}{l}\text { OR } 0.58 \text { ( } 0.29 \text { to } \\
1.16)\end{array}$ & $\begin{array}{l}576 \\
\text { (5 studies) }\end{array}$ & $\begin{array}{l}\oplus \oplus \odot \odot \\
\text { low2,10 }\end{array}$ & $\begin{array}{l}\text { The incidence } \\
\text { of adverse } \\
\text { events direct- }\end{array}$ & . \\
\hline
\end{tabular}


*The basis for the assumed risk (eg, the median control group risk across studies) is provided in footnotes. The corresponding risk (and its $95 \%$ confidence interval) is based on the assumed risk in the comparison group and the relative effect of the intervention (and its $95 \% \mathrm{Cl}$ ).

Cl: confidence interval; OR: odds ratio; RCTs: randomized controlled trials.

GRADE Working Group grades of evidence.

High quality: Further research is very unlikely to change our confidence in the estimate of effect.

Moderate quality: Further research is likely to have an important impact on our confidence in the estimate of effect and may change the estimate.

Low quality: Further research is very likely to have an important impact on our confidence in the estimate of effect and is likely to change the estimate.

Very low quality: We are very uncertain about the estimate.

a Of the 33 included RCTs, the acupuncture treatment type and period were heterogeneous. The treatment period for acupuncture ranged from one to three months. Acupoints varied across trials. The needling sensation could be provoked by manual stimulation or electrical stimulation.

bDowngraded one level for serious imprecision: small number of studies and wide confidence intervals.

cDowngraded one level for serious risk of bias: Among the four included trials, two trials had risk of performance bias or attrition bias.

dDowngraded one level for serious risk of bias: Among the three included trials, one trial had risk of performance bias.

eDowngraded one level for serious risk of bias: Among the two included trials, one trial had risk of performance bias.

fDowngraded two levels for very serious imprecision: single study and very wide confidence intervals.

gDowngraded one level for serious risk of bias: Among the three included trials, at least two trials had risk of performance bias or attrition bias.

hDowngraded one level for serious risk of bias: Among the five included trials, at least two trials had risk of performance bias or attrition bias.

iDowngraded one level for serious risk of bias: Among the six included trials, at least two trials had risk of performance bias or attrition bias.

jDowngraded one level for serious inconsistency: Reporting of adverse events varied between trials. 


\section{B A C K G R O U N D}

This review is the first update of a previously published review (Zhang 2005b).

\section{Description of the condition}

Stroke is a devastating disease with high morbidity and mortality. Stroke therapy is currently lacking in sufficient population-wide treatments, thus it is estimated that the numbers of first-ever stroke and stroke death will rise to 23 million and 7.8 million, respectively, by the year 2030 (Strong 2007). In China, stroke has become the leading cause of death, with a mortality rate of approximately 1.6 million among a population of 1.4 billion people. Furthermore, 2.5 million new strokes occur each year in China (Liu 2011), and the burden of stroke has increased over the past three decades (Wang 2017b). This reality drives researchers to test other adjunctive therapies including acupuncture in an attempt to reduce morbidity and mortality, especially given that approved and validated therapies for stroke, with the exception of aspirin and recombinant tissue plasminogen activator, are limited.

\section{Description of the intervention}

Acupuncture is one of the main physical therapies in Traditional Chinese Medicine (Sze 2002); it has been widely used to treat patients with stroke in China for more than hundreds of years $\mathrm{Hu}$ 1993). In recent years, acupuncture has attracted the attention of physicians and stroke survivors in Western countries (Hopwood 2008; Park 2005). However, evidence of its effectiveness in stroke rehabilitation is inconsistent.

\section{How the intervention might work}

Acupuncture may improve muscle movement (Zhang 2016), may exert various biochemical effects including up-regulating expression of hippocampal lipoprotein receptor-related protein (LRP1) as reported by Xue 2011 and down-regulating expression of interleukin (IL)-1 $\beta$ mRNA as described by Fang 2013, and may improve treatment response among those with neuroinflammatory disorders (Deng 2015). A previous study showed a time-wise coincidence with the occurrence of endogenous opioids and endorphins with use of acupuncture, which activates multiple efferent pathways to alter activities of numerous neural systems (Han 1982).

Notably, acupuncturists who perform acupuncture action must receive training in standardized acupuncture procedures, and they must be qualified and experienced to ensure uniformity. In addition, sterile disposable stainless steel needles should be used to ensure safety (Chau 2009; Hopwood 2008; Hsieh 2007; Zhang 2015). "De Chi," the needling sensation, is provoked at each point by manual stimulation (Chau 2009; Hopwood 2008; Park 2005). When electrical stimulation is used, the intensity of stimulation is increased until tingling, warmth (as reported by Hopwood 2008 and Hsieh 2007), or muscle contractions (as indicated by GosmanHedstrom 1998) around acupoints can be sensed by the patient.

\section{Why it is important to do this review}

Acupuncture is well accepted by doctors and patients in China. Although numerous studies have been conducted within and outside of China to examine the efficacy of acupuncture in stroke, trial results are not consistent (Sze 2002a). Over the past 10 years, several randomized controlled trials (RCTs) exploring the safety and efficacy of acupuncture have been published (Chau 2009; Hsieh 2007; Park 2005; Zhang 2015). The previous version of this review, which included 14 trials, showed no clear evidence of efficacy of acupuncture for acute stroke, but the evidence base was small and intention-to-treat analysis was rarely mentioned (Zhang 2005b). The aim of this updated review is to analyze systematically all relevant RCTs, including those published since 2003, when we last searched the literature.

\section{O B JECTIVES}

To assess whether acupuncture could reduce the proportion of people with death or dependency, while improving quality of life, after acute ischemic or hemorrhagic stroke.

\section{METHODS}

\section{Criteria for considering studies for this review Types of studies}

We included truly unconfounded randomized clinical trials (without restrictions of blinding, publication status, or language) comparing acupuncture with placebo or sham acupuncture, or open control (no placebo), in people with acute stroke. We excluded quasi-randomized trials (those that refer to allocation using the sequence of admission, alternate case record numbers, alternation, date of birth, or day of the week). We also excluded confounded trials in which the treatment or control group received another active therapy, for example, acupuncture versus other intervention, or acupuncture plus other intervention versus control.

\section{Types of participants}

People of any age or sex with any type of acute stroke (within 30 days of stroke onset) were eligible. Diagnosis of stroke was based on one of the following: (1) consistency with the World Health Organization definition, that is, "the focal neurological impairment occurs suddenly, lasts more than 24 hours or leads to death, and was presumed of vascular origin"; (2) purely clinical features; or (3) brain imaging alone (ie, magnetic resonance imaging [MRI] or computed tomography scanning $[\mathrm{CT}])$. We excluded trials that were restricted to people with subdural hematoma or subarachnoid hemorrhage.

\section{Types of interventions}

We included trials assessing acupuncture treatment in people with acute stroke within 30 days of onset, regardless of duration and times of treatment. We included trials using traditional acupuncture, which refers to insertion of needles in classical meridian points, or contemporary acupuncture, by which needles are inserted into trigger points or into nonmeridian points, irrespective of the method of stimulation (hand or electrical stimulation). The control group received placebo or sham acupuncture or no acupuncture treatment (open control). With open control, routine treatments such as drug therapy or rehabilitation or both would be the same as those given to the real/sham acupuncture group. However, real/sham acupuncture would not be given to participants in the open control group. We also included trials comparing acupuncture plus another treatment versus the other treatment alone, thereby assessing acupuncture. Placebo acupuncture indicates needling attaching to the surface of the skin. Sham acupuncture refers to (1) needling prick on the 
surface of the skin, by which needles are placed in an area that is close to but not at acupuncture points, and (2) electro-stimulation of subliminal skin via electrodes attached to the skin.

\section{Types of outcome measures}

\section{Primary outcomes}

The primary outcome was death or dependency at the end of follow-up. Dependency is defined as a state of being dependent on others for activities of daily living (ADL), for example, a Barthel Index (BI) score $\leq 60$, a modified Rankin Scale (MRS) grade of 3 to 6 , or the trialists' own definition. We included in a secondary analysis death or dependency reported in trials that followed participants for at least three months.

\section{Secondary outcomes}

1. Death or required institutional care or extensive family support at the end of follow-up. In developing countries, extensive family support can be the main form of care for patients with severe neurological deficit. We also performed a secondary analysis of institutional care or extensive family support for participants who were followed up for at least three months after stroke.

2. Changes in neurological deficit score at the end of the scheduled treatment period and at the end of follow-up ( $\geq$ three months after stroke onset). Measures could focus on (1) specific impairment (eg, Motricity Index, or Motor Assessment Scale, used to assess only motor function), or (2) global neurological deficit (eg, Canadian Neurological Scale [CNS], National Institutes of Health Stroke Scale [NIHSS], European Stroke Scale [ESS], Scandinavian Stroke Scale [SSS], modified Edinburgh-Scandinavian Stroke Scale (MESSS) used to assess neurological function, such as motor function, sensor function, etc.).

3. Death from all causes within the first two weeks of treatment and during the whole follow-up period

4. Quality of life (QOL), if assessed by included trials during the whole follow-up period

5. Adverse events (AEs) and severe AEs that may relate to acupuncture alone, including faintness, dizziness, pain, bleeding, high blood pressure, infection and heart tamponades, spinal cord injury, puncture of a lung, disrupted pacemaker function, and other effects presumed to be caused by acupuncture or electro-stimulation

\section{Search methods for identification of studies}

See the Specialized Register section in the Cochrane Stroke Group module. We searched for trials without language restrictions and translated relevant papers when necessary.

\section{Electronic searches}

We searched the Cochrane Central Register of Controlled Trials Ovid (CENTRAL Ovid; 2017, Issure 2) in the Cochrane Library; Appendix 1), MEDLINE Ovid (1946 to February 2017; Appendix 2), Embase Ovid (1974 to February 2017; Appendix 3), the Cochrane Stroke Group trials register (last searched by the Managing Editor on February 2, 2017), the Cumulative Index to Nursing and Allied Health Literature (CINAHL) EBSCO (1982 to February 2017; Appendix 4), the Allied and Complementary Medicine Database (AMED; 1985 to February 2017; Appendix 5), the China Academic Journal Network Publishing Database (1998 to February 2017), and the VIP database (VIP
Chinese Science Journal Evaluation Reports; 1989 to February 2017). We also identified relevant trials in the Chinese Clinical Trial Registry (www.chictr.org.cn/searchproj.aspx; last searched on February 20, 2017; Appendix 6), the World Health Organization (WHO) International Clinical Trials Registry Platform (apps.who.int/ trialsearch/; last searched on May 9, 2017; Appendix 7), and Clinicaltrials.gov (clinicaltrials.gov/; last searched on May 9, 2017; Appendix 8).

\section{Searching other resources}

We searched the reference lists of published systematic reviews of acupuncture for stroke and identified trials as we searched for relevant articles. We attempted to contact study authors of the included trials to ask for additional data; the authors of only four trials - Chen 1997, Gosman-Hedstrom 1998, Hopwood 2008, Johansson 2001 - provided additional data for the previous version of this review (Zhang 2005b). We pooled these unpublished data into meta-analyses in this updated review. We are grateful to these trial authors.

\section{Data collection and analysis}

\section{Selection of studies}

Two review authors (MX, DL) independently screened all studies identified by searching electronic databases and relevant references. We included eligible studies that met predetermined inclusion criteria and resolved disagreements through discussion, or by consultation with a third review author if necessary (SZ).

\section{Data extraction and management}

Two review authors (MX, DL) independently extracted data on study methods and characteristics of participants, interventions, and outcomes onto a data extraction form. We obtained additional information from study authors whenever possible.

\section{Assessment of risk of bias in included studies}

We evaluated risk of bias in included studies by establishing whether each trial met the following methodological domains according to the Cochrane Handbook for Systematic Reviews of Interventions (Higgins 2011).
1. Method of randomization.
2. Allocation concealment.
3. Blinding of participants and outcome assessors.
4. Intention-to-treat analysis.
5. Incomplete outcome data.
6. Selective outcome reporting.
7. Other bias.

We graded the risk of bias for each domain as high, low, or unclear. We provided information from the trial and justification for our judgement in "Risk of bias" tables. Two review authors (MX, DL) independently assessed risk of bias for each trial and resolved disagreements by discussion with a third review author (SZ).

\section{Measures of treatment effect}

We reported the results of dichotomous outcomes as odds ratios (ORs) with 95\% confidence intervals (Cls). For continuous outcomes, we used mean differences (MDs) (when outcomes were measured on the same scale) or standardized mean differences 
(SMDs) (when outcomes were measured on different scales), together with $95 \% \mathrm{Cls}$.

\section{Unit of analysis issues}

For studies with non-standard design, we managed data according to recommendations provided in the Cochrane Handbook for Systematic Reviews of Interventions (Higgins 2011).

\section{Dealing with missing data}

We contacted study authors for additional information whenever possible. However, no study authors replied to our requests for missing data. Notably, we pooled published data and unpublished data from four included RCTs into the meta-analyses (Chen 1997; Gosman-Hedstrom 1998; Hopwood 2008; Johansson 2001).

\section{Assessment of heterogeneity}

We assessed heterogeneity using the $\mathrm{I}^{2}$ statistic. We considered $\mathrm{I}^{2}>$ $50 \%$ as substantial heterogeneity. We performed all analyses using a random-effects model.

\section{Assessment of reporting biases}

We assessed reporting biases using funnel plots (Egger 1997).

\section{Data synthesis}

We tested differences between acupuncture and control groups (combined placebo/sham acupuncture and open control) through overall comparison. We separately compared acupuncture with sham acupuncture and open control. We performed all metaanalyses using Review Manager 5 (RevMan 2014). We used the fixedeffect approach for outcomes without substantial heterogeneity and the random-effects approach for those with substantial heterogeneity.

\section{Subgroup analysis and investigation of heterogeneity}

We preplanned the following subgroup analyses to investigate the effects of acupuncture.

1. Different stroke subtypes (ischemic or hemorrhagic stroke).

2. Different start times (within and after 10 days from stroke onset).

3. Different stroke severity, which was determined by NIHSS, SSS, MESSS, CNS, or ESS, or by trialists' own definition at baseline.

\section{Sensitivity analysis}

We planned to perform the following sensitivity analyses by excluding trials:

1. with open control;

2. in which adequate concealment of allocation was unclear; and

3. in which outcome evaluations were not blinded.

\section{"Summary of findings" tables}

We used GRADEpro (GRADEproGDT) software to retrieve data from RevMan and produced "Summary of findings" tables (Summary of findings for the main comparison; Summary of findings 2), which included the following.

1. A list of all important outcomes.

2. A measure of the typical burden of these outcomes, such as illustrative risk.

3. Relative effects.

4. Numbers of participants and studies addressing each outcome.

5. A grade of the overall quality of evidence for each outcome.

6. Comments.

We judged the quality of the evidence as "high," "moderate," "low," or "very low." We used the specific evidence grading system developed by the GRADE Collaboration (GRADE Working Group 2004) to judge the quality of evidence according to the Cochrane Handbook for Systematic Reviews of Interventions (Higgins 2011).

\section{RE S U L T S}

\section{Description of studies}

\section{Results of the search}

We identified 73,041 references from electronic databases and through handsearching. As shown in Figure 1, we excluded 15,530 duplicate references, 1458 references to animal experiments, 248 reviews, 102 systemic reviews or meta-analyses, 54,274 references that related to a different disease, 611 references that did not investigate acupuncture, and 725 references because of no control group, non-RCT, or non-acute stroke, leaving 93 potentially eligible RCTs for inclusion. 
Figure 1. Flow diagram.

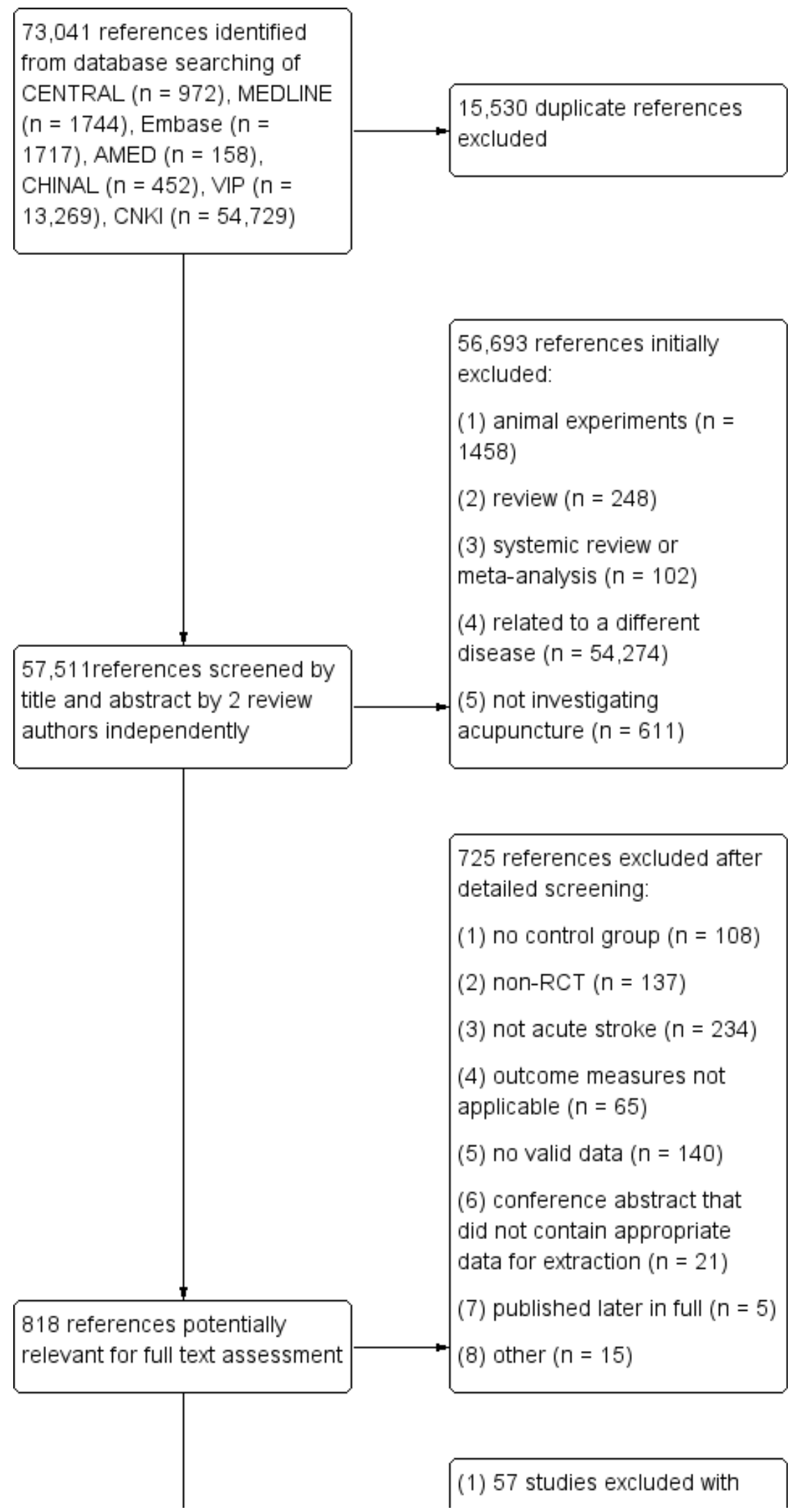


Figure 1. (Continued)

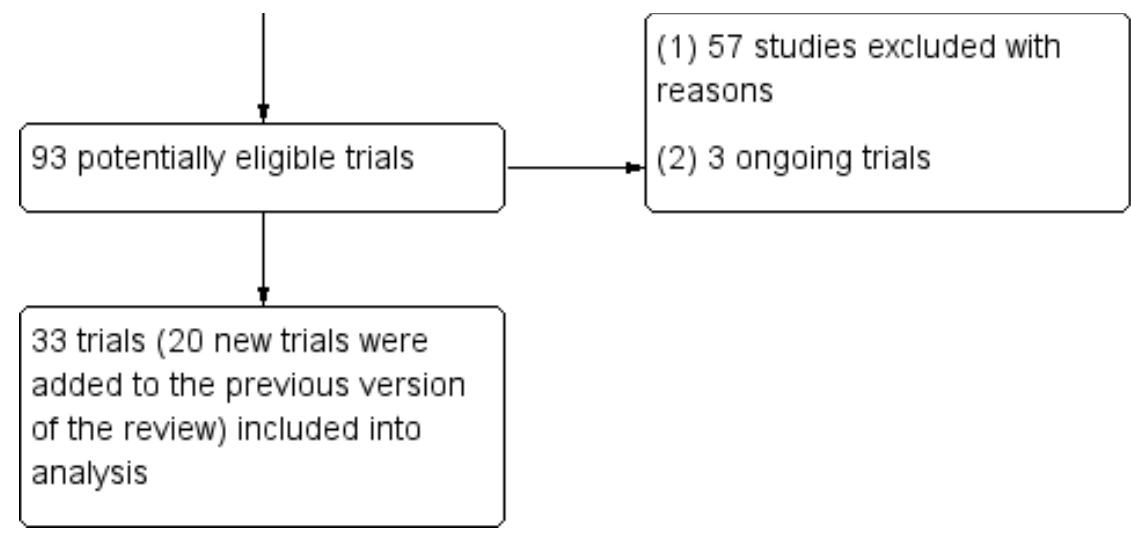

Of the 93 potentially eligible RCTs, we excluded 57 trials and added three ongoing trials. We therefore included in this version of the review 33 RCTs with a total of 3946 participants, 13 of which were included in the previous version (Cai 2002; Chen 1997; Duan 1997; Gosman-Hedstrom 1998; Hopwood 2008; Hu 1993; Huang 2002; Jin 1999; Johansson 1993; Johansson 2001; Sze 2002; Wu 2002; Yu 1993), and 20 new trials (Chau 2009; Chen 2007; Chen 2015; Chen 2016a; Dong 2006; Guo 2016; Hsieh 2007; Lin 2005; Liu 2016; Mu 2008; Ou 2014; Pang 2006; Park 2005; Shen 2012a; Shen 2012b; Wang 2008; Zhang 2005a; Zhang 2013; Zhang 2015; Zhu 2007).

\section{Included studies}

Of the 33 included RCTs, 28 were conducted in China (including Taiwan and Hong Kong), two in the UK, and three in Sweden. The mean age of participants ranged from 51 to 82 years. All RCTs included men and women. The rate of CT/MRI scanning was $100 \%$ in all except four trials (Chen 2016a; Hopwood 2008; Johansson 1993; Johansson 2001). Six trials included both ischemic and hemorrhagic stroke (Chen 2015; Pang 2006; Park 2005; Shen 2012a; Sze 2002; Wu 2002); two trials included participants with hemorrhagic stroke (Dong 2006; Guo 2016); the remaining trials included ischemic stroke, but for three of them we could not determine the subtype of stroke because of an incomplete rate of CT/MRI examination before entry (Hopwood 2008; Johansson 1993; Johansson 2001).

Apart from sham/placebo acupuncture, participants randomized to sham control were given drug therapy (Shen 2012b), rehabilitation therapy (Chau 2009; Gosman-Hedstrom 1998; Park 2005), or both (Hopwood 2008; Johansson 2001), as was the acupuncture group. Participants randomized to open control also received drug therapy (Cai 2002; Chen 1997; Dong 2006; Duan 1997; Guo 2016; Huang 2002; Jin 1999; Lin 2005; Liu 2016; Mu 2008; Ou 2014; Wang 2008; Wu 2002; Yu 1993; Zhang 2005a; Zhu 2007), rehabilitation therapy (Chen 2015; Chen 2016a; Gosman-Hedstrom 1998; Johansson 1993), or both (Chen 2007; Hsieh 2007; Hu 1993; Pang 2006; Shen 2012a; Sze 2002; Zhang 2013; Zhang 2015), as did the acupuncture group, while no real/sham acupuncture was given.

All included trials described the acupuncture methods used. Time to the start of acupuncture treatment, method of treatment, time each session lasted, and number of sessions differed among trials (see table of Characteristics of included studies for details of each trial). Overall, three trials evaluated eye acupuncture (Chen 2007; Pang 2006; Wang 2008), four scalp acupuncture (Cai
2002; Dong 2006; Duan 1997; Yu 1993), eight body acupuncture (Chau 2009; Chen 1997; Chen 2015; Shen 2012a; Shen 2012b; Sze 2002; Zhang 2013; Zhu 2007), and one eye, scalp, and body acupuncture (Guo 2016). The remaining 17 trials used both scalp and body acupuncture treatment. The acupuncture program was not described for all, but three trials used "Xing Nao Kai Qiao" acupuncture methods (Shen 2012a; Zhang 2005a; Zhang 2015).

Among the 33 included RCTs, one included three groups specifically, one intervention and two control groups (GosmanHedstrom 1998). The remaining trials included two groups - one intervention and one control group. In GosmanHedstrom 1998, all participants received conventional stroke rehabilitation. Participants in the acupuncture group were given deep acupuncture via manual or electrical stimulation. Manual stimulation was used on the non-paretic side until the special needle sensation, generally called "De Chi," was achieved. Electrical stimulation was used on the paretic side to achieve pronounced muscle contractions. Participants in the sham control group were given superficial acupuncture, by which needles were just placed under the skin and no manual or electrical stimulation was provided. Participants in the open control group were not given acupuncture.

The acupuncture treatment period was also heterogeneous among trials. Acupuncture treatment lasted one week in one trial (Huang 2002), approximately two weeks in nine trials (Cai 2002; Guo 2016; Lin 2005; Liu 2016; Ou 2014; Park 2005; Shen 2012a; Wang 2008; Yu 1993), approximately three weeks in five trials (Chen 1997; Chen 2016a; Mu 2008; Zhang 2005a; Zhang 2013), approximately one month in nine trials (Chen 2015; Dong 2006; Duan 1997; Hopwood 2008; Hsieh 2007; Hu 1993; Shen 2012b; Zhang 2015; Zhu 2007), 40 days in two trials (Jin 1999; Pang 2006), two months in one trial (Chau 2009), 10 weeks in four trials (Gosman-Hedstrom 1998; Johansson 1993; Johansson 2001; Sze 2002), three months in one trial (Chen 2007), and for an undetermined time in one trial (Wu 2002).

Thirteen included trials continued to follow participants after acupuncture treatment ended (Chen 2007; Chen 2016a; GosmanHedstrom 1998; Hopwood 2008; Hsieh 2007; Hu 1993; Johansson 1993; Johansson 2001; Liu 2016; Shen 2012a; Shen 2012b; Zhang 2005a; Zhang 2015), and the others stopped follow-up once acupuncture treatment had ended. Follow-up lasted one year in four trials (Gosman-Hedstrom 1998; Hopwood 2008; Johansson 1993; Johansson 2001), and follow-up was provided for six months 
in four trials (Hsieh 2007; Shen 2012b; Zhang 2005a; Zhang 2015). The remaining 25 trials followed participants for three months or less.

\section{Excluded studies}

We excluded 57 studies for the following reasons (see Characteristics of excluded studies).

1. Randomization was questionable (Cai 2002a; Yin 2013; Zhang 1999).

2. It was not possible to include usable data for the meta-analysis from the following: Fan 2014; Gu 2005; Guo 2006a; Jia 2007; Jiang 1998; Li 1999; Li 2000a; Li 2000b; Li 2001; Li 2009; Liu 2001; Liu 2002a; Liu 2002b; Liu 2003a; Liu 2010; Lv 2003; Sang 2013; Tang 1996; Wang 2001; Wang 2012a; Wang 2016; Xiong 2008; Xu 1997; Xu 2001; Yang 2001; Zhang 1996; Zhang 2011; Zhao 2000; Zhen 2011; Zhou 2000; Zhou 2002; Zhu 2013.

3. Data were questionable (data provided in the full text of the published paper were inconsistent) (Fu 2001).

4. The trial was confounded (Guo 2006b; Han 2016; Ma 1999; Pei 2001; Song 2016; Yun 2000; Zheng 1996).

5. Trial inclusion criteria provided no clear information on the course of stroke. Types of participants were questionable (Jiang 2009; Liu 2003b).

6. The trial aimed to assess effects of two kinds of acupuncture on acute stroke (acupuncture involving Du15 and Du16 in addition to other acupoints vs acupuncture involving other acupoints alone) (Li 1989).

7. Trials were quasi-randomized, and the scale that was used to evaluate neurological function did not include a detailed description or reference, so reliability was uncertain (Li 2008).

8. Participants who were within three days after stroke onset were included in the abstract, and participants who were within seven days after stroke onset were included in the main body of the text. In addition, the main text describes that 120 participants were enrolled and randomized in this study, discusses only 90 participants in the results section, and provides no information on the remaining 30 participants. Trial data were questionable (Wang 2007).

9. Trial inclusion criteria did not define the course of acute stroke (Liu 2015; Ruan 2012; Zhu 2012).

10.Trials were quasi-randomized (Si 1999; Yang 2011).

11. Trials provided sparse information on acupoints, how to stimulate, how long each session lasted, and how many sessions were provided. In addition, it was not possible to include usable data in the analysis (Wang 2014).

12.Acupuncture points were stimulated by using an adhesive surface electrode (Wong 1999).
13.This trial described methods that were inconsistent with normal clinical practice. In this trial,participants with acute ischemic stroke and Barthel Index $(\mathrm{BI})<70$ were included and randomized in the outpatient department. It was difficult to perform this trial in China. The type of study was questionable (Yu 2003).

14.The trial included patients with stroke with subarachnoid hemorrhage (Xia 2016).

\section{Risk of bias in included studies}

\section{Allocation}

All included trials explicitly stated that randomization occurred. Eighteen trials reported the method of randomization (Chau 2009; Chen 1997; Chen 2016a; Dong 2006; Gosman-Hedstrom 1998; Guo 2016; Hsieh 2007; Hopwood 2008; Johansson 1993; Johansson 2001; Liu 2016; Park 2005; Shen 2012a; Shen 2012b; Sze 2002; Yu 1993; Zhang 2005a; Zhang 2015), 14 trials reported concealment of allocation (Chen 2007; Chen 2016a; Gosman-Hedstrom 1998; Hopwood 2008; Hsieh 2007; Johansson 1993; Johansson 2001; Liu 2016; Park 2005; Shen 2012b; Sze 2002; Yu 1993; Zhang 2005a; Zhang 2015), and the remaining trials did not report how participants were randomized or how the allocation sequence was generated or concealed. We evaluated methods of randomization and concealment as introducing unclear risk of bias.

\section{Blinding}

Eleven trials reported that treatment was blinded to both participants and outcome assessors (Gosman-Hedstrom 1998; Johansson 2001; Park 2005), participants (Chau 2009; Shen 2012b), or outcome assessors (Chen 2016a; Hopwood 2008; Hsieh 2007; Liu 2016; Sze 2002; Wu 2002). The other trials failed to report blinding.

\section{Incomplete outcome data}

Seven trials reported the numbers lost to follow-up (Chen 2016a; Gosman-Hedstrom 1998; Hopwood 2008; Hsieh 2007; Johansson 2001; Shen 2012b; Zhang 2015). The rate of loss to follow-up ranged from $1 \%$ to $33.3 \%$. Six trials noted the number of withdrawals (Chau 2009; Hopwood 2008; Liu 2016; Park 2005; Sze 2002; Wu 2002). The rate of withdrawals ranged from $1.9 \%$ to $15.5 \%$. All participants in the remaining trials completed treatment and follow-up.

\section{Selective reporting}

Selective reporting bias was not clear because the protocols of 31 included RCTs were not available; protocols for only two trials were available (Chen 2016a; Zhang 2015).

\section{Other potential sources of bias}

The funnel plot with large number of trials investigating death or dependency at the end of follow-up showed a slightly asymmetrical funnel distribution, so publication bias may be present (Figure 2). 
Figure 2. Funnel plot of comparison: 1 Acupuncture versus control, outcome: 1.1 Death or dependency at end of follow-up.

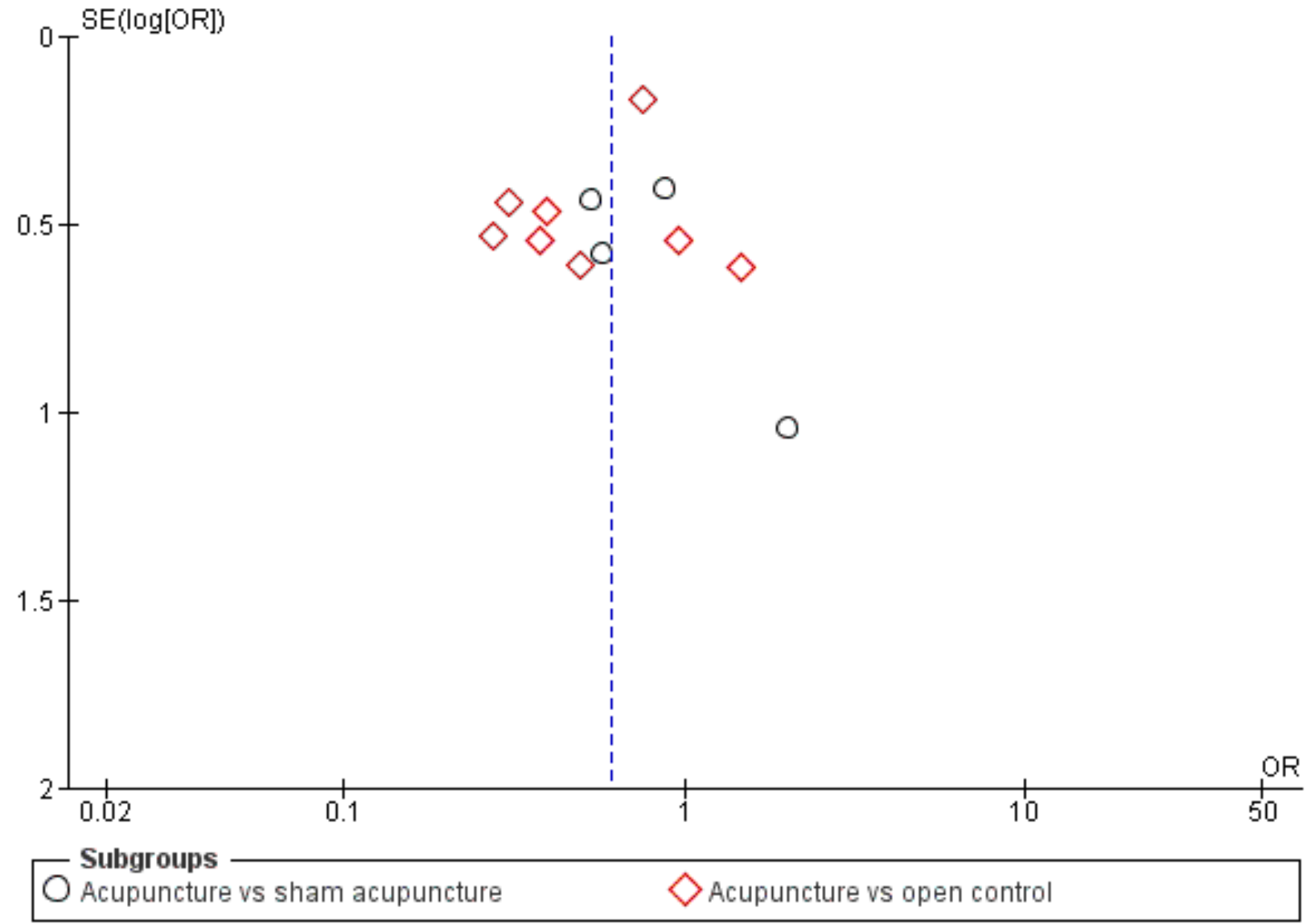

\section{Effects of interventions}

See: Summary of findings for the main comparison Acupuncture compared with all control (sham and open) for patients with acute stroke; Summary of findings 2 Acupuncture compared with sham control for patients with acute stroke

See Summary of findings for the main comparison and Summary of findings 2 .

\section{Primary outcome}

\section{Death or dependency at end of follow-up}

Eleven trials with a total of 1582 participants measured this outcome at the end of follow-up (Chau 2009; Chen 2007; Dong 2006; Gosman-Hedstrom 1998; Hopwood 2008; Johansson 1993; Johansson 2001; Pang 2006; Shen 2012a; Zhang 2005a; Zhang 2015). Investigators defined dependency as $\mathrm{BI} \leq 60$ (of a potential total of 100; Chen 2007; Chau 2009; Gosman-Hedstrom 1998; Johansson 1993; Johansson 2001; Shen 2012a; Zhang 2015), BI $\leq 70$ (of a potential total of 100; Dong 2006; Pang 2006), or BI $\leq 12$ (of a potential total of 20; Hopwood 2008), or by trialists' own definition (Zhang 2005a). Overall, participants in the acupuncture group were reported as less likely to be dead or dependent compared with those in the control group (OR $0.61,95 \% \mathrm{Cl} 0.46$ to 0.79 ; number needed to treat for an additional beneficial outcome [NNTB] $=11 ; 1^{2}$ $=14 \%$; very low-quality evidence; Analysis 1.1). We downgraded the evidence to very low quality for inconsistency and risk of bias. Also, when acupuncture was compared with sham acupuncture alone, the difference in death or dependency between the two groups was not significant (OR $0.71,95 \% \mathrm{Cl} 0.43$ to $1.18 ; 1^{2}=0 \%$; low-quality evidence).

Eight of 11 trials with 1436 participants followed participants for at least three months (Chen 2007; Gosman-Hedstrom 1998; Hopwood 2008; Johansson 1993; Johansson 2001; Shen 2012a; Zhang 2005a; Zhang 2015). Data show a significant effect of acupuncture on reducing death or dependency (OR $0.67,95 \% \mathrm{Cl} 0.53$ to $0.85 ; \mathrm{I}^{2}=0 \%$; very low-quality evidence; Analysis 1.2). When acupuncture was compared with sham acupuncture alone, the difference between the two groups was not significant (OR $0.67,95 \% \mathrm{Cl} 0.40$ to 1.12 ; $\left.\right|^{2}$ $=0 \%$; low-quality evidence).

\section{Secondary outcomes}

\section{Death or institutional care at end of follow-up}

Data for this outcome were available for five trials with 1120 participants (Gosman-Hedstrom 1998; Hopwood 2008; Hsieh 2007; Johansson 1993; Zhang 2015). All five trials followed up with participants for longer than three months after stroke. The numbers of participants living at home and needing extensive family support were not available. The numbers of participants living in rehabilitation units, nursing homes/old people's homes, and 
acute hospitals were included in the analysis as numbers requiring institutional care. Overall, data show a non-significant difference between acupuncture and control groups with regard to the outcome of death or institutional care (OR $0.78,95 \% \mathrm{Cl} 0.54$ to $1.12 ; 1^{2}=0 \%$; low-quality evidence; Analysis 1.3 ). When acupuncture was compared with sham acupuncture, data show a significant trend toward fewer deaths among participants and less need for institutional care (OR $0.47,95 \% \mathrm{Cl} 0.23$ to $0.96 ; \mathrm{I}^{2}=0 \%$; low-quality evidence).

\section{Changes in neurological deficit score and motor function score at end of treatment period and at end of follow-up ( $>$ three months)}

Changes in global neurological deficit score at the end of the treatment period could be extracted from 12 studies with a total of 1086 participants (Cai 2002; Chen 2016a; Duan 1997; GosmanHedstrom 1998; Guo 2016; Huang 2002; Lin 2005; Liu 2016; Mu 2008; Ou 2014; Wang 2008; Wu 2002). Global neurological function was measured by the MESSS (Cai 2002; Duan 1997; Guo 2016; Huang 2002; Lin 2005; Mu 2008; Ou 2014; Wang 2008; Wu 2002), the NIHSS (Chen 2016a; Liu 2016), or the SSS (Gosman-Hedstrom 1998). Overall, improvement in neurological deficit was more significant in the acupuncture group than in the control group (SMD 0.84, 95\% $\mathrm{Cl} 0.36$ to $1.32 ; \mathrm{I}^{2}$ = 92\%; very low-quality evidence; Analysis 1.4 ). We downgraded the evidence for this outcome to very low quality owing to both risk of bias and inconsistency. We noted no significant difference in changes in global neurological deficit score when acupuncture was compared with sham control (SMD 0.01, 95\% C -0.55 to $0.57 ;\left.\right|^{2}$ not applicable). Only two trials measured long-term changes in global neurological deficit score (> three months), and the difference between groups did not reach statistical significance (weighted mean difference [WMD] $-0.02,95 \% \mathrm{Cl}-0.37$ to 0.33 ) (Gosman-Hedstrom 1998; Liu 2016).

Data showing changes in motor function score at the end of the treatment period were available for 11 studies with 895 participants (Chau 2009; Chen 2016a; Hopwood 2008; Hsieh 2007; Johansson 1993; Johansson 2001; Liu 2016; Shen 2012a; Yu 1993; Zhang 2013; Zhu 2007). Researchers measured motor function using the Fugl-Meyer Assessment (Chau 2009; Chen 2016a; Hsieh 2007; Liu 2016; Shen 2012a; Zhang 2013; Zhu 2007), the Motricity Index (Hopwood 2008), motor function score (Johansson 1993), the Rivermead Mobility Index (Johansson 2001), or a mobility index (Yu 1993). Similarly, data show a significant trend toward greater improvement in motor function in the acupuncture group than in the control group (SMD 1.08, 95\% Cl 0.45 to $1.71 ; 1^{2}=94 \%$; very lowquality evidence; Analysis 1.5). We downgraded the evidence for this outcome to low quality owing to risk of bias and inconsistency. Also the difference was non-significant when acupuncture was compared with sham acupuncture alone (SMD $-0.10,95 \% \mathrm{Cl}-0.38$ to $0.17 ; 1^{2}=0 \%$; low-quality evidence). Three studies provided data on long-term motor function score (> three months); the difference in changes in motor function score between acupuncture and control groups was not significant (Analysis 1.6) (Hopwood 2008; Hsieh 2007; Johansson 2001).

We noted significant heterogeneity for the outcomes of changes in global neurological deficit score and motor function at the end of the treatment period, which may have been due to differences in scales, times of evaluation from stroke onset, and control groups.

\section{Death within first two weeks and during the whole follow-up period}

Eighteen studies with 1612 participants provided data on death within the first two weeks. Overall, few participants died (acupuncture group 6/799, 0.75\%; control group 8/813, 0.98\%) and data show no significant differences between groups (OR 0.91, 95\% $\mathrm{Cl} 0.33$ to $2.55 ; \mathrm{I}^{2}=0 \%$; low-quality evidence; Analysis 1.7 ). We downgraded the evidence for this outcome to low quality owing to risk of bias in the included trials. Also, when acupuncture was compared with sham acupuncture alone, the difference in death between the two groups was not significant (OR 1.20, 95\% Cl 0.27 to $5.26 ; 1^{2}=0 \%$; low-quality evidence).

Data on death during the whole follow-up period were available for 22 studies with 2865 participants. Similar to data on death within the first two weeks, a small number of participants in both the acupuncture group $(62 / 1422,4.36 \%)$ and the control group $(65 / 1443,4.50 \%)$ died (OR $1.08,95 \% \mathrm{Cl} 0.74$ to 1.58 ; $\mathrm{I}^{2}=0 \%$; lowquality evidence; Analysis 1.8). We downgraded the evidence for this outcome to low quality owing to risk of bias in included trials. Also, when acupuncture was compared with sham acupuncture alone, the difference in death between the two groups was not significant (OR $0.90,95 \% \mathrm{Cl} 0.47$ to $1.72 ; 1^{2}=0 \%$; low-quality evidence).

\section{Quality of life (QOL) at the end of follow-up}

Six studies investigated the effects of acupuncture on QOL. One trial used the EuroQoL-5-Dimensional Forma (EQ-5D) and the EuroQoL-Visual Analog Scale (EQ-VAS) (Park 2005). Results of this trial suggest that acupuncture was not superior to sham treatment. Another study used the Stroke-Specific Quality of Life Scale (SS-QOL) to study QOL at six months after stroke; results indicate that acupuncture may improve $\mathrm{QOL}$ at six months (Shen 2012b). The remaining four trials used Nottingham Health Profile (NHP) scores to investigate this outcome (Gosman-Hedstrom 1998; Hopwood 2008; Johansson 1993; Johansson 2001). However, the standard deviations for NHP in the four trials were not available, so we could not perform a meta-analysis for this outcome. Regarding the dimensions of pain and sleep, none of the trials showed a significant difference between the acupuncture group and the control group. Scores on energy show that acupuncture treatment was superior to control treatment; the difference was significant in two trials (Hopwood 2008; Johansson 1993), and it was non-significant in one trial (Johansson 2001). Also, data show a significant difference between groups with regard to the dimensions of mobility (Gosman-Hedstrom 1998; Johansson 1993), emotional reaction (Johansson 1993), and social isolation (Johansson 1993).

\section{Numbers with adverse events related to acupuncture treatment}

Among the 33 included trials, only one trial reported severe AEs, which occurred in both acupuncture and control groups, and noted no significant difference (Zhang 2015). Thirteen trials reported AEs that were directly related to acupuncture (Chau 2009; Chen 2015; Dong 2006; Gosman-Hedstrom 1998; Hopwood 2008; Hu 1993; Johansson 2001; Liu 2016; Park 2005; Shen 2012b; Sze 2002; Zhang 2005a; Zhang 2015). Of 1037 participants in the acupuncture group, $64(6.2 \%)$ were observed to have AEs and $14(1.4 \%)$ of them discontinued acupuncture because of pain (Zhang 2005a; Zhang 2015), erysipeloid arm infection (Gosman- 
Hedstrom 1998), and bruising from handling (Hopwood 2008). Common reported AEs of acupuncture included seizure (Park 2005), pain (Shen 2012b; Zhang 2005a; Zhang 2015), infection (GosmanHedstrom 1998; Zhang 2015), faint (Shen 2012b; Liu 2016; Zhang 2015), dizziness (Hu 1993; Zhang 2015), high blood pressure (Shen 2012b), and bruising at acupoints (two participants who were taking anticoagulants) (Hopwood 2008; Sze 2002). Five of the 13 trials above also recorded AEs related to sham acupuncture, which occurred in $8.0 \%$ (24/298) of participants. Data show no significant difference in the proportion of participants with AEs between acupuncture and sham treatment groups (OR $0.58,95 \% \mathrm{Cl} 0.29$ to $1.16 ;\left.\right|^{2}=0 \%$; Analysis 1.9). In Analysis 1.9, we pooled data only from trials that involved sham acupuncture. Differences in AEs between acupuncture and sham acupuncture were comparable. Given that participants in the open control group were not given acupuncture, we did not pool data from trials with open control for the metaanalysis.

\section{Sensitivity analyses}

\section{Excluding trials with open control}

We included in the analysis six trials with placebo/sham acupuncture (Chau 2009; Gosman-Hedstrom 1998; Hopwood 2008; Johansson 2001; Park 2005; Shen 2012b). Data show no beneficial effects of acupuncture for any outcomes except death or needing institutional care (OR $0.47,95 \% \mathrm{Cl} 0.23$ to 0.96 ; low-quality evidence).

\section{Excluding trials in which adequate concealment of allocation was unclear}

We included in the analysis 14 trials with adequate concealment of allocation (Chen 1997; Chen 2016a; Gosman-Hedstrom 1998; Hopwood 2008; Hsieh 2007; Johansson 1993; Johansson 2001; Liu 2016; Park 2005; Shen 2012b; Sze 2002; Yu 1993; Zhang 2005a; Zhang 2015). Fewer participants in the acupuncture group than in the control group were reported to be dead or dependent (OR 0.72 , $95 \% \mathrm{Cl} 0.56$ to 0.93$)$. However, significant effects of acupuncture were not observed for other outcomes.

\section{Excluding trials in which the outcome evaluation was not blinded}

For this analysis, we pooled data from 12 trials (Chau 2009; Chen 2016a; Gosman-Hedstrom 1998; Hopwood 2008; Hsieh 2007; Johansson 2001; Liu 2016; Park 2005; Shen 2012b; Sze 2002; Wu 2002; Zhang 2015). The likelihood of being dead or dependent was lower in the acupuncture group than in the control group (OR 0.76, $95 \% \mathrm{Cl} 0.58$ to 1.00 ). Data show no statistically significant effects of acupuncture for other outcomes.

\section{Subgroup analyses}

\section{Effects in ischemic and hemorrhagic stroke}

Of the 33 included trials, six trials included both ischemic and hemorrhagic stroke (Chen 2015; Pang 2006; Park 2005; Shen 2012a; Sze 2002; Wu 2002). Only two trials included participants with hemorrhagic stroke (Dong 2006; Guo 2016). The remaining trials included participants with ischemic stroke, but in three of them, several participants did not undergo a brain CT/MRI before entry (Hopwood 2008; Johansson 1993; Johansson 2001). Data show a non-significant subgroup difference between the two groups of trials with ischemic and hemorrhagic stroke for the primary outcome $\left(\mathrm{I}^{2}=33.7 \%, \mathrm{P}=0.22\right.$; Analysis 2.1$)$.

\section{Effects of time of the start of acupuncture (within and after 10 days from stroke onset)}

We could not perform this subgroup analysis because all trials included participants within 10 days of stroke onset.

\section{Effects of stroke severity determined by NIHSS, SSS, CNS, or ESS, or by trialists' own definition at baseline}

We could not perform this subgroup analysis because all trials included participants with different stroke severity.

\section{DISCUSSION}

\section{Summary of main results}

We included in this updated review 33 randomized clinical trials (RCTs) with a total of 3946 participants; we identified 20 new trials since publication of the previous version of the review. Although most trials assessed effects of acupuncture on activities of daily living ( $A D L)$, data on death or dependency were available from 11 trials with 1582 participants. Across trials using any control comparison, participants in the acupuncture group were reported to be less likely to be dead or dependent at the end of follow-up and to have improved neurological deficits, especially for motor function. Investigators provided no evidence of a difference for other trial outcomes. However, all these results are uncertain owing to very low-quality evidence and were not confirmed in sensitivity analyses using only sham acupuncture controls. Thus we must conclude that these apparent improvements in outcome with acupuncture in acute stroke are confounded by the high risk of bis related to use of open controls.

The reported incidence of adverse events directly related to acupuncture was about $6.2 \%$, and $1.4 \%$ of participants discontinued acupuncture owing to intolerable pain, infection, and bruising at acupoints. Adverse events were reported in $8 \%$ of participants who received sham acupuncture. Unfortunately, reporting of adverse events was incomplete.

In view of the many uncertainties related to quality of the evidence, additional large, high-quality randomized trials are required to confirm or refute the effects of acupuncture in acute stroke.

\section{Overall completeness and applicability of evidence}

In this review, we focused on the effects of acupuncture on ADL when used in the acute stage of stroke. Of 33 included trials,11 RCTs with a total of 1582 participants measured this outcome, and most trials evaluated the effects of acupuncture on neurological deficits. Acupuncture methods used in the included trials are common in clinical practice.

The present review had several limitations.

1. Follow-up in most of the included trials was completed within three months. With regard to recovery after stroke, long-term effects should be evaluated.

2. Heterogeneity among the included trials was huge. Potential reasons were (1) different outcome scales were used across trials; and (2) acupuncture methods and the time of starting acupuncture treatment varied. 
3. Only a small number of trials assessed the effects of acupuncture used in acute hemorrhagic stroke.

In the analysis of effects of acupuncture on the primary outcome, only two of eight trials with open control clearly stated blinding of outcome assessment (Gosman-Hedstrom 1998; Zhang 2015). The remaining six trials did not report sufficient information to permit judgement on detection bias (Chen 2007; Dong 2006; Johansson 1993; Pang 2006; Shen 2012a; Zhang 2005a). Close inspection of other results suggest that this finding reflects the number of participants classified as dependent rather than the number who have died because the data show few deaths (with an odds ratio [OR] of 1.08) (Analysis 1.8). The composite of death/institutional care also shows little evidence of an effect (Analysis 1.3). Measures of dependency are susceptible to performance/detection bias, which is showing up strongly in open control trials.

Given that only 12 of the 33 included trials reported sufficient information for judgement of performance/detection bias, we downgraded the evidence for the primary outcome and for secondary outcomes. Future studies with larger sample sizes, clear information on methods of randomization and concealment of allocation, and statements of whether participants, personnel, and outcome assessors were blinded are required to confirm the effects and safety of acupuncture.

\section{Quality of the evidence}

The quality of evidence varied across the 33 included trials. Overall, 18 trials reported the method of randomization, 14 adequately concealed the sequence of randomization, and 12 reported that treatment was blinded to participants or outcome assessors, or both. Seven trials performed intention-to-treat (ITT) analysis.

According to the five GRADE considerations, the quality of the body of evidence was low for the outcome of death at end of followup and long-term follow-up (three months or longer) and was very low for the other outcomes. The main reasons for downgrading evidence included risk of bias in included trials, inconsistency, and imprecision (see Summary of findings for the main comparison and Summary of findings 2).

\section{Potential biases in the review process}

We used a comprehensive search strategy for this updated review. We prepared a funnel plot for the primary outcome of death or dependency and found a slightly asymmetrical funnel distribution, which indicated the possibility of publication bias (Figure 2).

The Characteristics of included studies tables show risk of bias, as summarized in Figure 3 and Figure 4.

\section{Figure 3. Risk of bias graph: review authors' judgements about each risk of bias item presented as percentages} across all included studies.

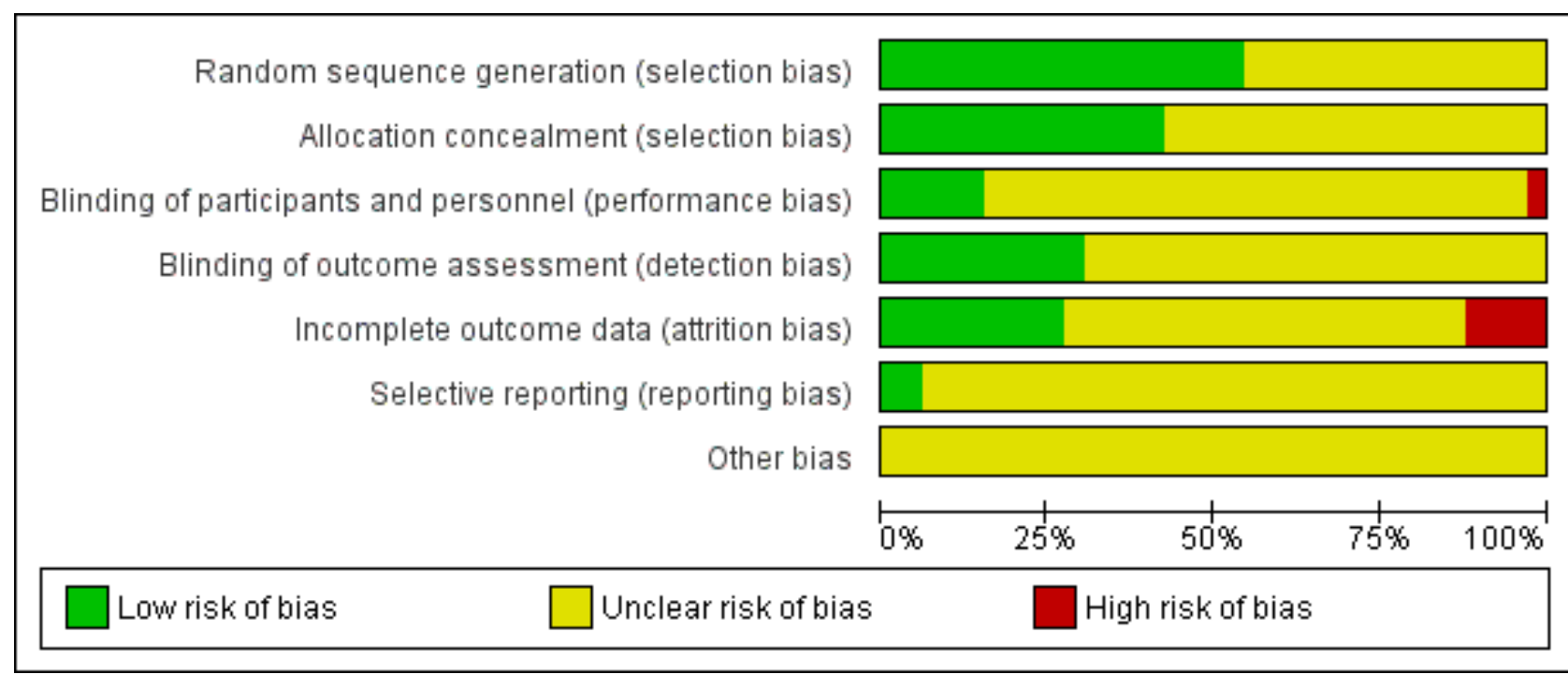


Figure 4. Risk of bias summary: review authors' judgements about each risk of bias item for each included study.

\begin{tabular}{|c|c|c|c|c|c|c|c|}
\hline & 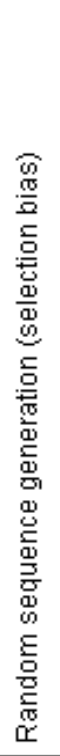 & 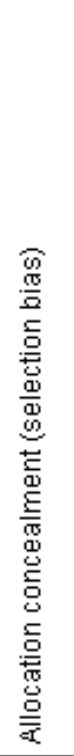 & 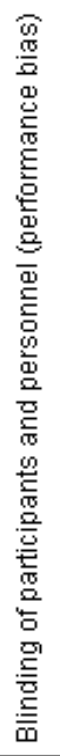 & 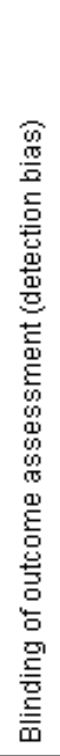 & 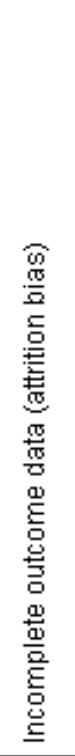 & 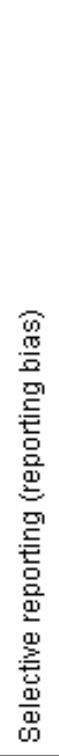 & 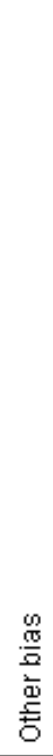 \\
\hline Cai 2002 & $?$ & $?$ & $?$ & $?$ & $?$ & $?$ & $?$ \\
\hline Chau 2009 & $\odot$ & $?$ & $\odot$ & $?$ & $\odot$ & $?$ & $?$ \\
\hline Chen 1997 & $\odot$ & $\oplus$ & $?$ & $?$ & $?$ & $?$ & $?$ \\
\hline Chen 2007 & $?$ & $?$ & $?$ & $?$ & $?$ & $?$ & $?$ \\
\hline Chen 2015 & $?$ & $?$ & $?$ & $?$ & $?$ & $?$ & $?$ \\
\hline Chen 2016a & $\odot$ & $\odot$ & ? & + & $\theta$ & + & $?$ \\
\hline Dong 2006 & $\odot$ & $?$ & $?$ & $?$ & $?$ & $?$ & $?$ \\
\hline Duan 1997 & $?$ & $?$ & $?$ & $?$ & $?$ & $?$ & $?$ \\
\hline Gosman-Hedstrom 1998 & $\odot$ & $\odot$ & $\odot$ & + & + & $?$ & $?$ \\
\hline Guo 2016 & $\odot$ & $?$ & $?$ & $?$ & $\odot$ & $?$ & $?$ \\
\hline Hopwood 2008 & $\odot$ & + & $\odot$ & + & + & $?$ & $?$ \\
\hline Hsieh 2007 & $\oplus$ & + & $?$ & + & $\odot$ & $?$ & $?$ \\
\hline Hu 1993 & ? & $?$ & ? & $?$ & ? & ? & ? \\
\hline Huang 2002 & $?$ & $?$ & $?$ & $?$ & $?$ & ? & ? \\
\hline $\operatorname{Jin} 1999$ & $?$ & $?$ & $?$ & $?$ & $?$ & ? & $?$ \\
\hline Johansson 1993 & $\odot$ & + & $?$ & $?$ & $?$ & $?$ & $?$ \\
\hline Johansson 2001 & + & $\odot$ & $\odot$ & $\odot$ & $\odot$ & $?$ & ? \\
\hline Lin 2005 & $?$ & $?$ & $?$ & $?$ & $?$ & $?$ & ? \\
\hline Liu 2016 & $\odot$ & + & $?$ & $\odot$ & 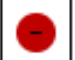 & $?$ & $?$ \\
\hline Mu 2008 & $?$ & $?$ & $?$ & $?$ & $?$ & $?$ & $?$ \\
\hline
\end{tabular}


Figure 4. (Continued)

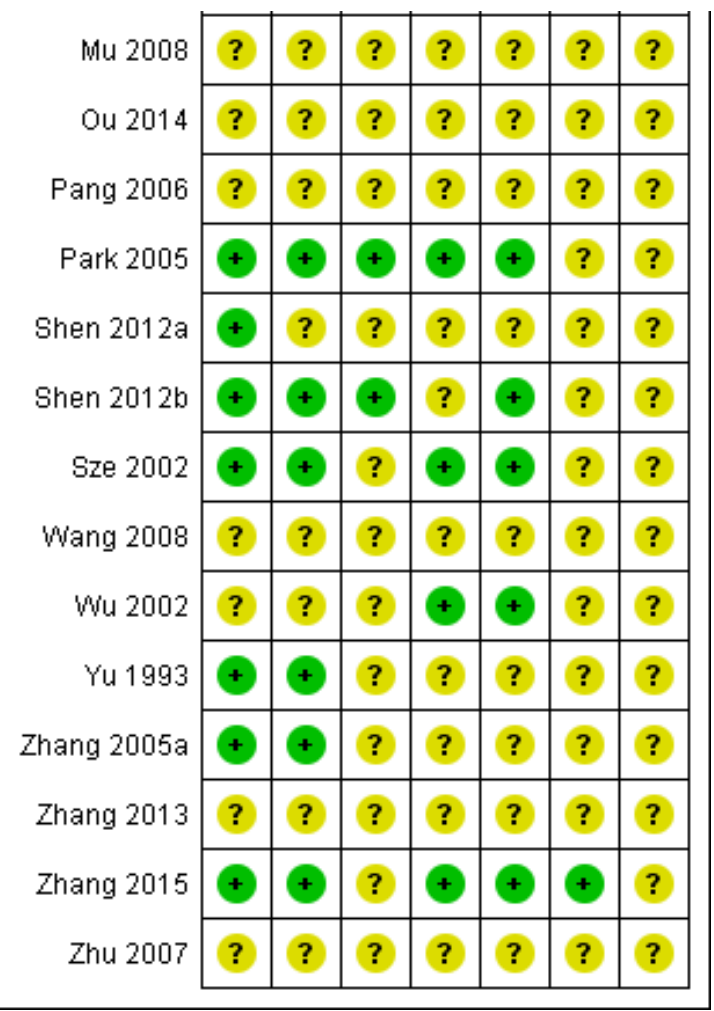

\section{Agreements and disagreements with other studies or reviews}

Several systematic reviews of acupuncture for stroke have been published before this updated review. One systematic review investigated the effects of long-term "Xingnao Kaiqiao needling" in people with ischemic stroke (Yang 2015). We included two trials with 126 participants in the meta-analyses on disability, results of which indicated that "Xingnao Kaiqiao needling" could reduce the poststroke disability rate, which is consistent with the findings of our review. Another systematic review investigated the effect of acupuncture for the outcome of death or dependency (Zheng 2011), whereas no trial in this review reported this outcome. A third systematic review, which included patients with stroke in both the acute and the non-acute stage, demonstrated the efficacy of acupuncture in poststroke rehabilitation, whereas review authors did not report the effects of acupuncture on ADL and in the acute stage alone (Wu 2010).

Three systematic reviews evaluated scalp acupuncture for people with acute ischemic stroke (Wang 2012b), acute hypertensive intracerebral hemorrhage (Zheng 2011), or stroke (Bai 2015). All three reviews drew similar conclusions that scalp acupuncture was useful in improving neurological deficits. Six trials included in one review focused on the effect of scalp acupuncture on neurological deficit scores in acute ischemic stroke (Wang 2012b); only one trial stated the method of randomization, and no trial reported allocation concealment or the blinding procedure. Furthermore, selective reporting bias might be present in the RCTs included in this review, characterized as co-intervention reported and similarity of baseline (Wang 2012b). In Bai 2015, data on changes in neurological deficit score and motor function were available, and this trial did not report the method of randomization, allocation concealment, or the blinding procedure. Thus the results of these two reviews should be interpreted with caution because the included trials were of low quality (Bai 2015; Wang 2012b). In the review of acupuncture for acute intracerebral hemorrhage (Zheng 2011), investigators assessed neurological deficit improvement by using the rate of reduction in neurological deficit scores at baseline rather than changes in neurological deficit score as used in the present review.

Two systematic reviews that investigated sham-controlled RCTs found no positive effect of acupuncture on functional recovery after stroke (Kong 2010; Wu 2010), which was consistent with findings of the subgroup analysis reported in the present review. However, we do not think that sham acupuncture as the control is necessary in a pragmatic trial because sham acupuncture may have an underlying physiological effect (Bao 2014; Moffet 2009; Zhang 2015).

\section{AUTHORS' CONCLUSIONS}

\section{Implications for practice}

In this review, the apparent reduction in dependency and improvement in neurological recovery with acupuncture in acute stroke are confounded by risk of bias related to use of open controls. Adverse events with acupuncture were generally reported to be minor and usually did not result in stopping treatment.

\section{Implications for research}

Among the 33 included trials, only 18 reported information about randomization and 12 reported blinding. Future studies, with larger sample sizes, clear information on methods of randomization and concealment of allocation, and statements on whether participants, personnel, and outcome assessors were blinded, 
are required to assess the effects and safety of acupuncture. Future studies should pay specific attention to the effects of acupuncture on long-term functional outcomes. Notably, only two trials in this updated review investigated the effects of acupuncture on hemorrhagic stroke. Data show possible differences between symptoms and consequently between the results of acupuncture in patients with ischemic versus hemorrhagic stroke; thus wider research studies in the future should be sure to include people with hemorrhagic stroke. In addition, further reliable studies in other ethnic populations (alongside the Asian ones) are required to identify population-specific response differences.

\section{ACKNOWLEDGEMENTS}

We thank Hazel Fraser (Managing Editor, Cochrane Stroke Group) for the search of the Cochrane Stroke Group trials register, and Brenda Thomas (Trials Search Co-ordinator) and Joshua Cheyne (Information Specialist) for the searches of CINAHL and AMED databases. We acknowledge with thanks the useful comments and the work of Prof Peter Langhorne, who spent time helping to revise this updated review. We also thank Valentina Assi, Joshua Cheyne, Maree Hackett, Hongmei Wu, Julie Gildie, Odie Geiger, and Heather Goodare for their many useful comments. We thank Prof Ming Liu for her contribution to previous versions of this review. 


\section{RE F E R E N C E S}

\section{References to studies included in this review}

Cai 2002 \{published data only\}

Cai JY, Pan JY. Scalp acupuncture and early blood vessel reopening. Shanghai Journal of Aupuncture and Moxibustion 2002;21(4):9-10.

\section{Chau 2009 \{published data only\}}

Chau ACM, Cheung RTF, Jiang X, Au-Yeung P, Li LSW. Acupuncture of motor-implicated acupoints on subacute stroke patients: an fMRI evaluation study. Medical Acupuncture 2009;21(4):233-41.

\section{Chen 1997 \{published and unpublished data\}}

Chen SQ, Wang YP, Li YX. Effects of acupuncture on neck in the treatment of 95 cases of acute cerebral infarction. Chinese Journal of Rehabilitation Therapy and Practice 1997;3(4):161-2.

\section{Chen 2007 \{published data only\}}

Chen YF, Mao M, Chen X, Mou X, Bai Y. Eye acupuncture combined with exercise therapy for the treatment of limb dyskinesia due to cerebral infarction: a report of 40 cases. Journal of New Chinese Medicine 2007;39(11):25-6.

\section{Chen 2015 \{published data only\}}

Chen XJ. The effect of acupuncture on early neurological rehabilitation in patients with acute ischemic stroke. Journal of Sichuan of Traditional Chinese Medicine 2015;33(5):155-6.

Chen 2016a \{published data only\}

Chen L, Fang J, Ma R, Gu X, Chen L, Li J, et al. Additional effects of acupuncture on early comprehensive rehabilitation in patients with mild to moderate acute ischemic stroke: a multicenter randomized controlled trial. BMC Complementary and Alternative Medicine 2016;16:226.

\section{Dong 2006 \{published data only\}}

Dong JW, Bao CL, Gong XZ. Clinical observational study of scalp penetration acupuncture for acute hypertensive hemorrhage. Clinical Journal of Traditional Chinese Medicine 2006;18(4):341-2.

\section{Duan 1997 \{published data only\}}

Duan GJ, Tang Q, Zhang CY, Yang Y, Zhang B. Comparison of effects of acupuncture on cerebral infarction in different parts. Chinese Acupuncture and Moxibustion 1997;10:591-3.

\section{Gosman-Hedstrom 1998 \{published and unpublished data\}}

Gosman-Hedstrom G, Claessson L, Klingenstierna U, Carlsson J, Olausson B, Frizell M, et al. Effects of acupuncture treatment on daily life activities and quality of life. Stroke 1998;29:2100-8.

\section{Guo 2016 \{published data only\}}

Guo Q, Liu RH. Randomized parallel control study on eye acupuncture, scalp acupuncture, electroacupuncture and medicine therapy of cerebral hemorrhage in basal ganglia region in early stage. Journal of Practical Traditional Chinese Internal Medicine 2016;30(8):94-7.
Hopwood 2008 \{published and unpublished data\}

Hopwood V, Lewith G, Prescott P, Campbell MJ. Evaluating the efficacy of acupuncture in defined aspects of stroke recovery: a randomised, placebo controlled single blind study. Journal of Neurology 2008;255:858-66.

Hsieh 2007 \{published data only\}

Hsieh RL, Wang LY, Lee WC. Additional therapeutic effects of electroacupuncture in conjunction with conventional rehabilitation for patients with first-ever ischaemic stroke. Journal of Rehabilitation Medicine 2007;39:205-11.

\section{Hu 1993 \{published data only\}}

Hu H-H, Chung C, Liu TJ, Chen RC, Chen CH, Chou P, et al. $A$ randomized controlled trial on the treatment for acute partial ischemic stroke with acupuncture. Neuroepidemiology 1993;12:106-13.

\section{Huang 2002 \{published data only\}}

Huang JP, Zeng HK, Zhen XF, Sun C, Li H. Short-term effect of first-aid acupoint pricking blood therapy on cerebral infarction. Shanghai Journal of Acupuncture and Moxibustion 2002;21(4):7-8.

\section{Jin 1999 \{published data only\}}

Jin ZQ, Gu FL, Chen RX, Cheng JS. Clinical investigation of acupuncture effect on acute cerebral infarction. Acupuncture Research 1999;1:5-7.

\section{Johansson 1993 \{published data only\}}

Johansson K, Lindgren I, Winder H, Wiklund I, Johansson BB. Can sensory stimulation improve the functional outcome in stroke patients?. Neurology 1993;43:2189-92.

\section{Johansson 2001 \{published and unpublished data\}}

Johansson BB, Haker E, von Arbin M, Britton M, Langstrom G, Terent $A$, et al. Acupuncture and transcutaneous nerve stimulation in stroke rehabilitation: a randomized, controlled trial. Stroke 2001;32:707-13.

\section{Lin 2005 \{published data only\}}

Lin MX, Zhou SH, Shen QW, Wang SZ, Zhang QC, Lin LQ. Influence analysis on the hemodynamics to the treatment of cerebral infarction with acupuncture therapy and medicine at an early stage. Journal of Practical Medical Techniques 2005;12:671-3.

\section{Liu 2016 \{published data only\}}

Liu CH, Hsieh YT, Tseng HP, Lin HC, Lin CL, Wu TY, et al. Acupuncture for a first episode of acute ischaemic stroke: an observer-blinded randomised controlled pilot study. Acupuncture in Medicine 2016;34:349-55.

\section{Mu 2008 \{published data only\}}

Mu YY, Li ZR, Cheng J, Bao C, Hu JL, Yang GX. Observations on the influence of acupuncture on serum IL- 6 and IL-8 in patients with acute cerebral infarction. Shanghai Journal of Acupuncture and Moxibustion 2008;27(11):3-5. 
Ou 2014 \{published data only\}

Ou Y-Y, Zhang DS, Huang Y. Study of clinical effect of circulation needling method on ischemic stroke in acute stage. Hebei Journal of Traditional Chinese Medicine 2014;36(5):715-8.

\section{Pang 2006 \{published data only\}}

Pang LL. Ocular acupuncture combined with exercise training for 68 cases with acute stroke. Jilin Journal of Traditional Chinese Medicine 2006;26(5):49-50.

\section{Park 2005 \{published data only\}}

Park J, White AR, James MA, Hemsley AG, Johnson P, Chambers J, et al. Acupuncture for subacute stroke rehabilitation: a sham-controlled, subject- and assessorblind, randomized trial. Archives of Internal Medicine 2005;165:2026-31.

\section{Shen 2012a \{published data only\}}

Shen J, Deng HL, Cui Y. Observation on clinical therapeutic effect of early acupuncture combined with modern rehabilitation intervention on hemiplegia after stroke. Chinese Journal of Industry Medicine 2012;15(4):480-2.

Shen 2012b \{published data only\}

Shen PF, Kong L, Ni LW, Guo HL, Yang S, Zhang L-L, et al. Acupuncture intervention in ischemic stroke: a randomized controlled prospective study. American Journal of Chinese Medicine 2012;40(4):685-93.

\section{Sze 2002 \{published data only\}}

Sze FK, Wong E, Yi X, Woo J. Does acupuncture have additional value to standard poststroke motor rehabilitation?. Stroke 2002;33:186-94.

\section{Wang 2008 \{published data only\}}

Wang PQ, Wang J, Zhou HF. Influence of eye acupuncture on neural deficit and plasma fibrinogen level in acute cerebral infarction patients. Shanghai Journal of Acupuncture and Moxibustion 2008;27(3):5-7.

\section{Wu 2002 \{published data only\}}

Wu XL, Zou Q, Cai DJ, Tang Y, Zhao ZY, Zeng XR. Clinical observation on rehabilitation of nervous functions in the patient of stroke at acute stage treated with acupuncture. Chinese Acupuncture and Moxibustion 2002;22(11):726-8.

\section{Yu 1993 \{published data only\}}

Yu ZS, Sai XB, Tang Q, Tong X, Yu H, Xu Q, et al. Effects of scalp acupuncture on acute cerebral infarction. Shanghai Journal of Acupuncture and Moxibustion 1993;12(2):52-3.

\section{Zhang 2005a \{published data only\}}

Zhang HP, Zhang L, Lu HB. Clinical study of acupuncture for acute ischemic stroke. Journal of Practical Diagnosis and Therapy 2005;19(2):144-5.

\section{Zhang 2013 \{published data only\}}

Zhang C, Liu J, Lin QH, Zeng TJ, Li MY, Lu X-X, et al. Effect of electrical acupuncture on the movement functions of the patients with acute cerebral infarction. Journal of Traditional Chinese Medicine University of Hunan 2013;33(2):79-80.
Zhang 2015 \{published data only\}

Zhang SH, Wu B, Liu M, Li N, Zeng XR, Liu H, et al. Acupuncture efficacy on ischemic stroke recovery multicenter randomized controlled trial in China. Stroke 2015;46:1301-6.

\section{Zhu 2007 \{published data only\}}

Zhou SH, Lin MX, Wang SZ. Influence of electric stimulation on motor function of upper limb in patients with acute ischemic stroke. Journal of Practical Traditional Chinese Medicine 2007;23(4):238-9.

\section{References to studies excluded from this review}

Cai 2002a $\{$ published data only\}

Cai LH. The effect of scalp acupuncture in the treatment of 170 cases of acute cerebral infarction. Beijing Journal of Traditional Chinese Medicine 2002;21(4):239-40.

Fan 2014 \{published data only\}

Fan CG, Fu GH, Shan HX. Clinical effects of activating brain and muscles acupuncture therapy treating acute cerebral infarction. Journal of Nanjing University of Traditional Chinese Medicine 2014;30(4):379-82.

Fu 2001 \{published data only\}

Fu WB, Fan L, Li WX. Treatment of acute cerebral infarction by eye acupuncture. Shanghai Journal of Acupuncture and Moxibustion 2001;20(3):14-5.

\section{Gu 2005 \{published data only\}}

Gu W, Liu L, Gao Y, Xiang YZ, Pang Y, Liu C, et al. Mechanism of ischemic preconditioning effect of acupuncture in treating acute cerebral infarction. Chinese Journal of Clinical Rehabilitation 2005;9(41):88-9.

\section{Guo 2006a \{published data only\}}

Guo ZL. Acupuncture combined with medicine for 46 patients with acute ischemic stroke. Jiangsu Journal of Traditional Chinese Medicine 2006;27(2):43-5.

\section{Guo 2006b \{published data only\}}

Guo ZJ, Liu LA, Wang LM, Zhang GP, Guo YL. The effect of dynamic acupuncture on motor function in acute stroke. Acta Academiae Medicinae Qingdao Universitatis 2006;42(1):32-33,36.

\section{Han 2016 \{published data only\}}

Han JY, Kim JH, Park JH, Song MY, Song MK, Kim DJ, et al. Scalp acupuncture and electromagnetic convergence stimulation for patients with cerebral infarction: study protocol for a randomized controlled trial. Trials 2016;17(1):490.

\section{Jia 2007 \{published data only\}}

Jia QS, Mi XJ, Zhao RQ, Zhao XL. The effect of scalp acupuncture and body acupuncture for 107 cases with acute ischemic stroke. Journal of Practical Traditional Chinese Internal Medicine 2007;21(4):99-100.

Jiang 1998 \{published data only\}

Jiang SH, Meng QG, Tang Q, Kong QA. Effect of scalp acupuncture combined with urokinase on acute cerebral 
infarction. Acta Chinese Medicine and Pharmacology 1998;3:512.

\section{Jiang 2009 \{published data only\}}

Jiang HF. Eye acupuncture and exercise therapy treatment of 30 cases of stroke recovery. Journal of Practical Traditioal Chinese Internal Medicine 2009;23(5):95-6.

\section{Li 1989 \{published data only\}}

Li DM, Li WD, Wei LH, Zhao YL, Lu HZ. Clinical observation on acupuncture therapy for cerebral hemorrhage. Journal of Traditional Chinese Medicine 1989;9(1):9-13.

\section{Li 1999 \{published data only\}}

Li Q, Xiao JH, Dong GY. Clinical study of the effects of scalp acupuncture on acute cerebral hemorrhage. Chinese Journal of Integrated Traditional and Western Medicine 1999;19(4):203-5.

\section{Li 2000a \{published data only\}}

Li CP, Yang HS, Zhang YL, Kan JF. Effects of acupuncture on plasm endothelin in patients with acute ischemic stroke. Acupuncture Research 2000;25(3):214-5.

Li 2000b \{published data only\}

Li CY. Clinical study of effects of acupuncture for acute ischemic study. Clinical Journal of Acupuncture and Moxibustion 2000;16(9):7-10.

\section{Li 2001 \{published data only\}}

Li AH, Liu YS, Shang CS, Yan XM. Clinical study on acupuncture based on principle of Xing Nao Kai Qiao in early stage of ischemic stroke. Clinical Journal of Acupuncture and Moxibustion 2001;17(11):39-40.

\section{Li 2008 \{published data only\}}

Li HY, Wang B, Li ZL, Wu Y. Clinical study of acupuncture on yin-yang-pair-point for the rehabilitation of paralytic limbs in patients with ischemic stroke. Journal of Clinical Acupuncture and Moxibustion 2008;24(10):18-9.

\section{Li 2009 \{published data only\}}

Li XQ, Li K. Observational study of acupuncture for acute ischemic stroke. Chinese Acupuncture and Moxibustion 2009;Supplement:5-6.

\section{Liu 2001 \{published data only\}}

Liu QX, Zhang ZC, Zhang HL. Clinical study on treatment of 160 cases of acute ischemic apoplexy mainly with acupuncture. Chinese Acupuncture and Moxibustion 2001;21(10):583-5.

\section{Liu 2002a \{published data only\}}

Liu HY, Zhu LF, Xie DL, Li Y. Effects of rehabilitation combined with acupuncture on acute ischemic stroke. Chinese Journal of Clinical Rehabilitation 2002;6(17):2610-1.

\section{Liu 2002b \{published data only\}}

Liu Y, Ling FM, Zhang XP, Long MH. Early rehabilitation of acute stroke with acupuncture. Chinese Journal of Rehabilitation Theory and Practice 2002;8(11):689-90.

\section{Liu 2003a \{published data only\}}

Liu XH. Clinical observation of acupuncture of intracerebral hemorrhage. Chinese Journal of Integrated Traditional and Western Medicine 2003;93(9):715-6.

\section{Liu 2003b \{published data only\}}

Liu CR, Qiu ZF. Effects of different treatment methods in stroke rehabilitation. Journal of Clinical Acupuncture and Moxibustion 2003;19(2):25-6.

\section{Liu 2010 \{published data only\}}

Liu HX, Zhao YN, Feng JY. Acupuncture for acute ischemic stroke: a report of 45 cases. Chinese Journal of Basic Medicine in Traditional Chinese Medicine 2010;16(10):923-6.

\section{Liu 2015 \{published data only\}}

Liu JH, Dong HS, Bao CL, Dong GR. Clinical research on the treatment of acute apoplexy of opportunity by scalp penetration acupuncture. China Journal of Chinese Medicine 2015;30(205):914-6.

\section{Lv 2003 \{published data only\}}

Lv LJ, Fan GQ, Zhu LP, Wu X. Clinical study on the treatment of acupuncture on cerebral infarction with upper extremity motor dysfunction. Zhejiang Journal of Integrated Traditional Chinese and Western Medicine 2003;13(1):14-5.

\section{Ma 1999 \{published data only\}}

Ma SH, Dun XR, Yu FH. Clinical study on acute ischemic stroke. Beijing Chinese Medicine 1999;5:18-9.

\section{Pei 2001 \{published data only\}}

Pei J, Sun L, Zhu T, Qian Y, Yuan D. The effect of electroacupuncture on motor function recovery in patients with acute cerebral infarction: a randomly controlled trial. Journal of Traditional Chinese Medicine 2001;21(4):270-2.

Ruan 2012 \{published data only\}

Ruan S, Zhang YW. The influence of acupuncture on serum IL-10 and IL-6 in patients with acute ischemic stroke. Journal of New Chinese Medicine 2012;44(10):102-5.

Sang 2013 \{published data only\}

Sang P, Wang S, Zhao JH. The study of protective mechanism of scalp acupuncture for acute ischemic stroke: a report of 40 cases. Acupuncture Guiding Learning 2013;11(10):44-5.

Si 1999 \{published data only\}

Si QM, Wu GC, Cao XL. Effects of electroacupuncture on acute cerebral infarction. Chinese Acupuncture and Moxibustion 1993;3:137-9.

\section{Song 2016 \{published data only\}}

Song Y, Kang L, Dong H, Chen Y. Combined rehabilitation with scalp cluster acupuncture and constraint-induced movement therapy significantly improved functional recovery in patients with acute ischemic stroke. International Journal of Clinical and Experimental Medicine 2016;9(10):19797-802. 
Tang 1996 \{published data only\}

Tang QS, Shun ST. Clinical and experimental study on scalp acupuncture in the treatment of acute cerebral infarction. Journal of Beijing University of Traditional Chinese Medicine 1996;19(4):37-9.

\section{Wang 2001 \{published data only\}}

Wang CY, Wang WY. Effects of electroacupuncture on apoprotein in patients with acute cerebral infarction. Journal of Traditional Chinese Medicine 2001;42(7):409-10.

\section{Wang 2007 \{published data only\}}

Wang PQ, Li JL, Wang J. Influences of eye needles in acute ischemic stroke on neurological dysfunction and serum Cresponse protein level. Journal of Clinical Acupuncture and Moxibustion 2007;23(12):23-4.

Wang 2012a \{published data only\}

Wang GW. Clinical research of acupuncture in the treatment acute stage of apoplexy. China Journal of Chinese Medicine 2012;27(7):919-20.

\section{Wang 2014 \{published data only\}}

Wang CW, Wu ZC, Li N, Zhao Y, Tian FW. Clinical curative effect of electric acupuncture on acute cerebral infarction: a randomized controlled multicenter trial. Journal of Traditional Chinese Medicine 2014;34(6):635-40.

\section{Wang 2016 \{published data only\}}

Wang HQ, Bao CL, Jiao ZH, Dong GR. Efficacy and safety of penetration acupuncture on head for acute intracerebral hemorrhage: a randomized controlled study. Medicine 2016;95(48):e5562.

\section{Wong 1999 \{published data only\}}

Wong AMK, Su TY, Tang FT, Cheng PT, Liaw MY. Clinical trial of electrical acupuncture on hemiplegic stroke patients. American Journal of Physical Medicine and Rehabilitation 1999;78(2):117-22.

\section{Xia 2016 \{published data only\}}

Xia W, Zheng C, Zhu S, Tang Z. Does the addition of specific acupuncture to standard swallowing training improve outcomes in patients with dysphagia after stroke? A randomized controlled trial. Clinical Rehabilitation 2016;30(3):237-46.

\section{Xiong 2008 \{published data only\}}

Xiong J, Wei MT, Du YH, Shi XM. Dynamic observation on the clinical effect of acupuncture therapy on acute cerebral infarction in super early stage. Acta Academicae Medicinae CPAF 2008;17(7):561-4.

\section{Xu 1997 \{published data only\}}

Xu YL. Effects of batroxobin combined with acupuncture in the treatment of 60 cases of acute cerebral infarction. Forum on Traditional Chinese Medicine 1997;12(4):35.

\section{Xu 2001 \{published data only\}}

Xu ZF, Guo ZJ, Guo YL, Shi BX. Effects of early rehabilitation and acupuncture intervention on motor function recovery of acute stroke patients. Chinese Journal of Physical Medicine and Rehabilitation 2001;23(4):226-8.

Yang 2001 \{published data only\}

Yang HB. Effects of acupuncture in early stage of ischemic stroke. Journal of Hubei College of Traditional Chinese Medicine 2001;3(3):38-9.

\section{Yang 2011 \{published data only\}}

Yang QW, Zhang DS, Wang SX. The acupuncture on four seas shu point in the treatment of acute ischemic stroke. Journal of Clinical Acupuncture and Moxibustion 2011;27(3):36-8.

Yin 2013 \{published data only\}

Yin Y, Zhao JS, Meng FZ, Li ZW, Li P. Clinical research on timeeffect of acupuncture treatment for the improvement of neurological deficit after acute intracerebral hemorrhage. Journal of Sichuan of Traditional Chinese Medicine 2013;31(10):111-2.

Yu 2003 \{published data only\}

Yu CD, Wu BH, Hong AH, Bai JY, Yu Z. Effects of scalp acupuncture combined with drugs at early stage of cerebral infarction. Chinese Acupuncture and Moxibustion 2003;23(2):67-9.

Yun 2000 \{published data only\}

Yun Y, Zhang J, Zhao R. The early effect of fire acupuncture on acute cerebral infarction. Chinese Acupuncture and Moxibustion 2000;3:151-2.

\section{Zhang 1996 \{published data only\}}

Zhang XS, Yuan YM. The changes of vasoactive intestinal peptide somatostatin and pancreatic polypeptide in blood and CSF of acute cerebral infarction patients and the effect of acupuncture. Acupuncture Research 1996;21(4):10-6.

\section{Zhang 1999 \{published data only\}}

Zhang QC, Luo LB, Yu L, Zhang LD, Zhang YM. Effect of needling on the 6 treating-paralysis acupoints on acute stroke. Clinical Journal of Acupuncture and Moxibustion 1999;15(3):46-8.

\section{Zhang 2011 \{published data only\}}

Zhang HM, Tang Q. Rehabilitation evaluation on post-stroke abnormal movement pattern prevented and treated with acupuncture and rehabilitation. Chinese Acupuncture and Moxibustion 2011;31(6):487-92.

\section{Zhao 2000 \{published data only\}}

Zhao J, Meng LY, Zhang J. Clinical observation of effect of acupuncture on acute ischemic stroke. Acta Chinese Medicine and Pharmacology 2000;4:54.

Zhen 2011 \{published data only\}

Zhen J, Ou JY, Zhang Lei, Yang YJ, Fan JZ. Clinical observation of acupuncture using xingnao kaiqiao needling method and rehabilitation training on stroke. Chinese Journal of Rehabilitation Theory and Practice 2011;17(4):370-2. 
Zheng 1996 \{published data only\}

Zheng JG, Zhou JZ. Effects of acupuncture with manipulation of "arouse brain and orifice opening" on acute cerebral hemorrhage. Journal of Tianjing College of Traditional Chinese Medicine 1996;4:21-3.

\section{Zhou 2000 \{published data only\}}

Zhou DM, Yang J, Shen TL, Yu ZG. Effects of acupuncture in the treatment of 32 cases of cerebral infarction with hemorrhagic transformation. Clinical Journal of Acupuncture and Moxibustion 2000;16(2):6-7.

\section{Zhou 2002 \{published data only\}}

Zhou W, Wang LP, Liu H, Bian G. Influence of scalp acupuncture on serum tumor necrosis factor in patients with acute cerebral infarction. Shanghai Journal of Acupuncture and Moxibustion 2002;21(1):11-2.

\section{Zhu 2012 \{published data only\}}

Zhu GQ, Hu Rong, Wu YH, Zhong XY. Refreshing yin and yang through barbed treatment of acute cerebral infarction. Liaoning Journal of Traditional Chinese Medicine 2012;39(2):312-4.

Zhu 2013 \{published data only\}

Zhu Y, Zhang LX, Ouyang G, Meng DH, Qian KL, Ma JH, et al. Acupuncture in subacute stroke: no benefits detected. Physical Therapy 2013;93(11):1447-55.

\section{References to ongoing studies}

Chen 2014 \{published data only\}

Chen LF, Fang JQ, Ma RJ, Froym R, Gu XD, Li JH, et al. Acupuncture for acute stroke: study protocol for a multicenter, randomized, controlled trial. Trials 2014;15:214.

\section{Chen 2016b \{published data only\}}

Chen L, Fang J, Jin X, Keeler CL, Gao H, Fang Z, et al. Acupuncture treatment for ischemic stroke in young adults: protocol for a randomised, sham-controlled clinical trial. BMJ Open 2016;6(1):e010073.

\section{Wang 2017a \{published data only\}}

Wang C, You C, Ma L, Liu M, Tian M, Li N. Acupuncture for acute moderate thalamic hemorrhage: randomized controlled trial study protocol. BMC Complementary and Alternative Medicine 2017;17(1):112.

\section{Additional references}

\section{Bai 2015}

Bai ZH, Zhang ZX, Li CR. Eye acupuncture treatment for stroke: a systematic review and meta-analysis. Evidence-based Complementary and Alternative Medicine 2015;2015:871327.

\section{Bao 2014}

Bao T, Cai L, Snyder C, Betts K, Tarpinian K, Gould J, et al. Patient-reported outcomes in women with breast cancer enrolled in a dual-center, double-blind, randomized controlled trial assessing the effect of acupuncture in reducing aromatase inhibitor-induced musculoskeletal symptoms. Cancer 2014;120(3):381-9.

\section{Deng 2015}

Deng J, Lv E, Yang J. Electroacupuncture remediates glial dysfunction and ameliorates neurodegeneration in the astrocytic $\alpha$-synuclein mutant mouse model. Journal of Neuroinflammation 2015;12:103.

\section{Egger 1997}

Egger M, Davey Smith G, Schneider M, Minder C. Bias in meta-analysis detected by a simple, graphical test. BMJ 1997;315(7109):629-34.

\section{Fang 2013}

Fang JQ, Zhu SX, Zhang Y. Effect of electroacupuncture on expression of phosphorylated P38MAPK and IL-1 in frontal lobe and hippocampus in rat with Alzheimer's disease. Zhen Ci Yan Jiu 2013;38:35-9.

\section{GRADE Working Group 2004}

GRADE Working Group. Grading quality of evidence and strength of recommendations. BMJ 2004;328:1490.

\section{GRADEproGDT [Computer program]}

McMaster University (developed by Evidence Prime). GRADEproGDT (version accessed April 2017). Hamilton (ON): McMaster University (developed by Evidence Prime), Available from gradepro.org.

\section{Han 1982}

Han JS, Terenius L. Neurochemical basis of acupuncture analgesia. Annual Review of Pharmacology and Toxicology 1982;22:193-220.

\section{Higgins 2011}

Higgins JPT, Green S (editors). Cochrane Handbook for Systematic Reviews of Interventions Version 5.1.0 (updated March 2011). The Cochrane Collaboration, 2011. Available from www.cochrane-handbook.org.

\section{Kong 2010}

Kong JC, Lee MS, Shin BC, Song YS, Ernst E. Acupuncture for functional recovery after stroke: a systematic review of sham-controlled randomized clinical trials. Canadian Medical Association Journal 2010;182(16):1723-9.

\section{Liu 2011}

Liu L, Wang D, Wong KS, Wang Y. Stroke and stroke care in China: huge burden, significant workload, and a national priority. Stroke 2011;42(12):3651-4.

\section{Moffet 2009}

Moffet HH. Sham acupuncture may be as efficacious as true acupuncture: a systematic review of clinical trials. Journal of Alternative and Complementary Medicine 2009;15(3):213-6.

\section{RevMan 2014 [Computer program]}

The Nordic Cochrane Centre, The Cochrane Collaboration. Review Manager 5 (RevMan 5). Version 5.3. Copenhagen: The Nordic Cochrane Centre, The Cochrane Collaboration, 2014. 


\section{Strong 2007}

Strong K, Mathers C, Bonita R. Preventing stroke: saving lives around the world. Lancet Neurology 2007;6(2):182-7.

\section{Sze 2002a}

Sze FK, Wong E, Or KK, Lau J, Woo J. Does acupuncture improve motor recovery after stroke? A meta-analysis of randomized controlled trials. Stroke 2002;33(11):2604-19.

\section{Wang 2012b}

Wang Y, Shen J, Wang XM, Fu DL, Chen CY, Lu LY, et al. Scalp acupuncture for acute ischemic stroke: a meta-analysis of randomized controlled trials. Evidence-based Complementary and Alternative Medicine 2012;2012:480950.

\section{Wang 2017b}

Wang W, Jiang B, Sun H, Ru X, Sun D, Wang L, et al. Prevalence, incidence, and mortality of stroke in China: results from a nationwide population-based survey of 480687 adults. Circulation 2017;135(8):759-71.

\section{Wu 2010}

Wu P, Mills E, Moher D, Seely D. Acupuncture in poststroke rehabilitation: a systematic review and meta-analysis of randomized trials. Stroke 2010;41(4):e171-9.

\section{CHARACTERISTICS OF STUDIES}

Characteristics of included studies [ordered by study ID]

\section{Xue 2011}

Xue WG, Zhang Z, Xu H. Effect of electroacupuncture on learning-memory ability, and Abeta and LRP1 immunoactivity in hippocampal sulcus microvessels in APP transgenic mice. Zhen Ci Yan Jiu 2011;36:95-100.

\section{Yang 2015}

Yang ZX, Xie JH, Liu YP. Systematic review of long-term Xingnao Kaiqiao needling efficacy in ischemic stroke treatment. Neural Regeneration Research 2015;10(4):583-8.

\section{Zhang 2016}

Zhang W, Shi B, Zhou R. Improving the synergy of muscle movement is one of the important mechanisms in acupuncture analgesia. Zhongguo Zhen Jiu 2016;36(2):200-2.

\section{Zheng 2011}

Zheng GQ, Zhao ZM, Wang Y. Meta-analysis of scalp acupuncture for acute hypertensive intracerebral hemorrhage. Journal of Alternative and Complementary Medicine 2011;17(4):293-9.

\section{References to other published versions of this review Zhang 2005b}

Zhang SH, Liu M, Asplund K, Li L. Acupuncture for acute stroke. Cochrane Database of Systematic Reviews 2005, Issue 2. [DOI: 10.1002/14651858.CD003317.pub2]

\section{Cai 2002}

$\begin{array}{ll}\text { Methods } & \text { RCT, method of randomization not stated } \\ \text { Concealment of allocation }(C): \text { not stated } \\ \text { Blinding: not stated } \\ \text { ITT analysis: not stated } \\ \text { Losses to FU: none }\end{array}$

\section{Participants}

Country: China

76 participants ( 40 men, aged 46 to 74 years) with acute ischemic stroke were included in the analysis.

Treatment: 35, control: 41

$\leq 4$ hours from stroke onset

$100 \%$ CT scan before entry

Health conditions before stroke: without severe mental disease, dementia, Parkinson's disease, heart failure, hepatic failure, or severe renal dysfunction

Comparability: unclear

Interventions

Treatment group: 2 scalp acupoints, manual twirling stimulation, 40 minutes/session for 2 weeks, but total number of sessions not stated

Control group: no acupuncture

Both groups: drug therapy including vitamin C, citicoline, and gegengsu

Outcomes Change in MESSS score at 14 days

Notes

FU: 14 days 
Cai 2002 (Continued)

\section{Risk of bias}

\begin{tabular}{|c|c|c|}
\hline Bias & Authors' judgement & Support for judgement \\
\hline $\begin{array}{l}\text { Random sequence genera- } \\
\text { tion (selection bias) }\end{array}$ & Unclear risk & Insufficient information to permit judgement \\
\hline $\begin{array}{l}\text { Allocation concealment } \\
\text { (selection bias) }\end{array}$ & Unclear risk & Insufficient information to permit judgement \\
\hline $\begin{array}{l}\text { Blinding of participants } \\
\text { and personnel (perfor- } \\
\text { mance bias) } \\
\text { All outcomes }\end{array}$ & Unclear risk & Insufficient information to permit judgement \\
\hline $\begin{array}{l}\text { Blinding of outcome as- } \\
\text { sessment (detection bias) } \\
\text { All outcomes }\end{array}$ & Unclear risk & Insufficient information to permit judgement \\
\hline $\begin{array}{l}\text { Incomplete outcome data } \\
\text { (attrition bias) } \\
\text { All outcomes }\end{array}$ & Unclear risk & Insufficient information to permit judgement \\
\hline $\begin{array}{l}\text { Selective reporting (re- } \\
\text { porting bias) }\end{array}$ & Unclear risk & Insufficient information to permit judgement \\
\hline Other bias & Unclear risk & Insufficient information to permit judgement \\
\hline
\end{tabular}

\section{Chau 2009}

\begin{tabular}{ll}
\hline Methods & RCT, computer-generated random number list \\
C: unclear & Blinding: patients \\
ITT analysis: not stated \\
Number of withdrawals: 1 in treatment group, 4 in control group
\end{tabular}

Interventions

Treatment group: 3 motor-implicated acupoints (LI4, PC6, LI11), unilaterally on the paretic hand of the participants, manual twirling and electrical stimulation,

30 minutes/session, 3 times a week over 8 weeks

Control group: sham acupuncture, 3 non-motor-implicated acupoints (TE4, LU6, LI12), method of acupuncture as above

Both groups: routine, inpatient stroke rehabilitation program including physical and occupational therapy 
Chau 2009 (Continued)

\section{Adverse events}

Number of deaths

\begin{tabular}{ll}
\hline Notes & FU: 8 weeks
\end{tabular}

Risk of bias

\begin{tabular}{|c|c|c|}
\hline Bias & Authors' judgement & Support for judgement \\
\hline $\begin{array}{l}\text { Random sequence genera- } \\
\text { tion (selection bias) }\end{array}$ & Low risk & Computer-generated random number list \\
\hline $\begin{array}{l}\text { Allocation concealment } \\
\text { (selection bias) }\end{array}$ & Unclear risk & Insufficient information to permit judgement \\
\hline $\begin{array}{l}\text { Blinding of participants } \\
\text { and personnel (perfor- } \\
\text { mance bias) } \\
\text { All outcomes }\end{array}$ & Low risk & Blinding of patients \\
\hline $\begin{array}{l}\text { Blinding of outcome as- } \\
\text { sessment (detection bias) } \\
\text { All outcomes }\end{array}$ & Unclear risk & Insufficient information to permit judgement \\
\hline $\begin{array}{l}\text { Incomplete outcome data } \\
\text { (attrition bias) } \\
\text { All outcomes }\end{array}$ & High risk & $\begin{array}{l}1 \text { in treatment group and } 4 \text { in control group did not finish predetermined treat- } \\
\text { ment and evaluation schedules. }\end{array}$ \\
\hline $\begin{array}{l}\text { Selective reporting (re- } \\
\text { porting bias) }\end{array}$ & Unclear risk & Insufficient information to permit judgement \\
\hline Other bias & Unclear risk & Insufficient information to permit judgement \\
\hline
\end{tabular}

\section{Chen 1997}

\begin{tabular}{|c|c|}
\hline Methods & $\begin{array}{l}\text { RCT, using random number table } \\
\text { C: random number list read by doctor not entering participants into trial } \\
\text { Blinding: not stated } \\
\text { ITT analysis: not stated } \\
\text { Losses to FU: none }\end{array}$ \\
\hline Participants & $\begin{array}{l}\text { Country: China } \\
167 \text { participants ( } 82 \text { men, aged } 28 \text { to } 82 \text { years) with acute ischemic stroke } \\
\text { Treatment: } 95 \text {, control: } 72 \\
2 \text { to } 72 \text { hours from stroke onset } \\
100 \% \text { CT scan before entry } \\
\text { Health conditions before stroke: not stated } \\
\text { Comparability: age similar, more participants with multiple cerebral infarction and more females in } \\
\text { acupuncture group }\end{array}$ \\
\hline Interventions & $\begin{array}{l}\text { Treatment group: } 2 \text { acupoints (ST 9), manual twirling stimulation, } 10 \text { minutes/session, once a day for } \\
20 \text { days } \\
\text { Control group: no acupuncture }\end{array}$ \\
\hline
\end{tabular}


Chen 1997 (Continued)

Both groups: routine drug therapy

\begin{tabular}{ll}
\hline Outcomes & Number of participants with improvement (MESSS score decrease $>18 \%$ ) at 20 days \\
\hline Notes & FU: 20 days \\
\hline
\end{tabular}

\section{Risk of bias}

\begin{tabular}{|c|c|c|}
\hline Bias & Authors' judgement & Support for judgement \\
\hline $\begin{array}{l}\text { Random sequence genera- } \\
\text { tion (selection bias) }\end{array}$ & Low risk & Random number table used \\
\hline $\begin{array}{l}\text { Allocation concealment } \\
\text { (selection bias) }\end{array}$ & Low risk & Random number list read by doctor not entering participants into the trial \\
\hline $\begin{array}{l}\text { Blinding of participants } \\
\text { and personnel (perfor- } \\
\text { mance bias) } \\
\text { All outcomes }\end{array}$ & Unclear risk & Insufficient information to permit judgement \\
\hline $\begin{array}{l}\text { Blinding of outcome as- } \\
\text { sessment (detection bias) } \\
\text { All outcomes }\end{array}$ & Unclear risk & Insufficient information to permit judgement \\
\hline $\begin{array}{l}\text { Incomplete outcome data } \\
\text { (attrition bias) } \\
\text { All outcomes }\end{array}$ & Unclear risk & Insufficient information to permit judgement \\
\hline $\begin{array}{l}\text { Selective reporting (re- } \\
\text { porting bias) }\end{array}$ & Unclear risk & Insufficient information to permit judgement \\
\hline Other bias & Unclear risk & Insufficient information to permit judgement \\
\hline
\end{tabular}

\section{Chen 2007}

\begin{tabular}{|c|c|}
\hline Methods & $\begin{array}{l}\text { RCT, method of randomization not stated } \\
\text { Blinding: not stated } \\
\text { ITT analysis: not stated } \\
\text { Losses to FU: none }\end{array}$ \\
\hline Participants & $\begin{array}{l}\text { Country: China } \\
80 \text { participants ( } 46 \text { men, aged } 40 \text { to } 80 \text { years) with acute ischemic stroke } \\
\text { Treatment: } 40 \text {, control: } 40 \\
\text { Within } 10 \text { days from stroke onset } \\
100 \% \text { CT/MRI scan before entry } \\
\text { Health conditions before stroke: without severe medical disease, such as heart failure, hepatic failure, } \\
\text { severe renal dysfunction, infection, or shock } \\
\text { Comparability: age, sex, MESSS similar }\end{array}$ \\
\hline Interventions & $\begin{array}{l}\text { Treatment group: } 4 \text { areas of main acupoints (bilateral upper and lower energizer) and } 6 \text { areas of auxil- } \\
\text { iary acupoints (hepatic area, cardiac area, renal area, spleen area, bile area, and middle energizer) ac- } \\
\text { cording to clinical symptoms, manual stimulation, } 30 \text { minutes/session, } 5 \text { sessions a week for } 3 \text { months } \\
\text { Control group: no acupuncture }\end{array}$ \\
\hline
\end{tabular}


Chen 2007 (Continued)

Both groups: routine drug therapy and exercise training

\begin{tabular}{ll}
\hline Outcomes & SSS, BI, and FMA before and after treatment \\
& Number of $\mathrm{BI}<60$ points after treatment \\
Number of deaths
\end{tabular}

\section{Risk of bias}

\begin{tabular}{|c|c|c|}
\hline Bias & Authors' judgement & Support for judgement \\
\hline $\begin{array}{l}\text { Random sequence genera- } \\
\text { tion (selection bias) }\end{array}$ & Unclear risk & Insufficient information to permit judgement \\
\hline $\begin{array}{l}\text { Allocation concealment } \\
\text { (selection bias) }\end{array}$ & Unclear risk & Insufficient information to permit judgement \\
\hline $\begin{array}{l}\text { Blinding of participants } \\
\text { and personnel (perfor- } \\
\text { mance bias) } \\
\text { All outcomes }\end{array}$ & Unclear risk & Insufficient information to permit judgement \\
\hline $\begin{array}{l}\text { Blinding of outcome as- } \\
\text { sessment (detection bias) } \\
\text { All outcomes }\end{array}$ & Unclear risk & Insufficient information to permit judgement \\
\hline $\begin{array}{l}\text { Incomplete outcome data } \\
\text { (attrition bias) } \\
\text { All outcomes }\end{array}$ & Unclear risk & Insufficient information to permit judgement \\
\hline $\begin{array}{l}\text { Selective reporting (re- } \\
\text { porting bias) }\end{array}$ & Unclear risk & Insufficient information to permit judgement \\
\hline Other bias & Unclear risk & Insufficient information to permit judgement \\
\hline
\end{tabular}

Chen 2015

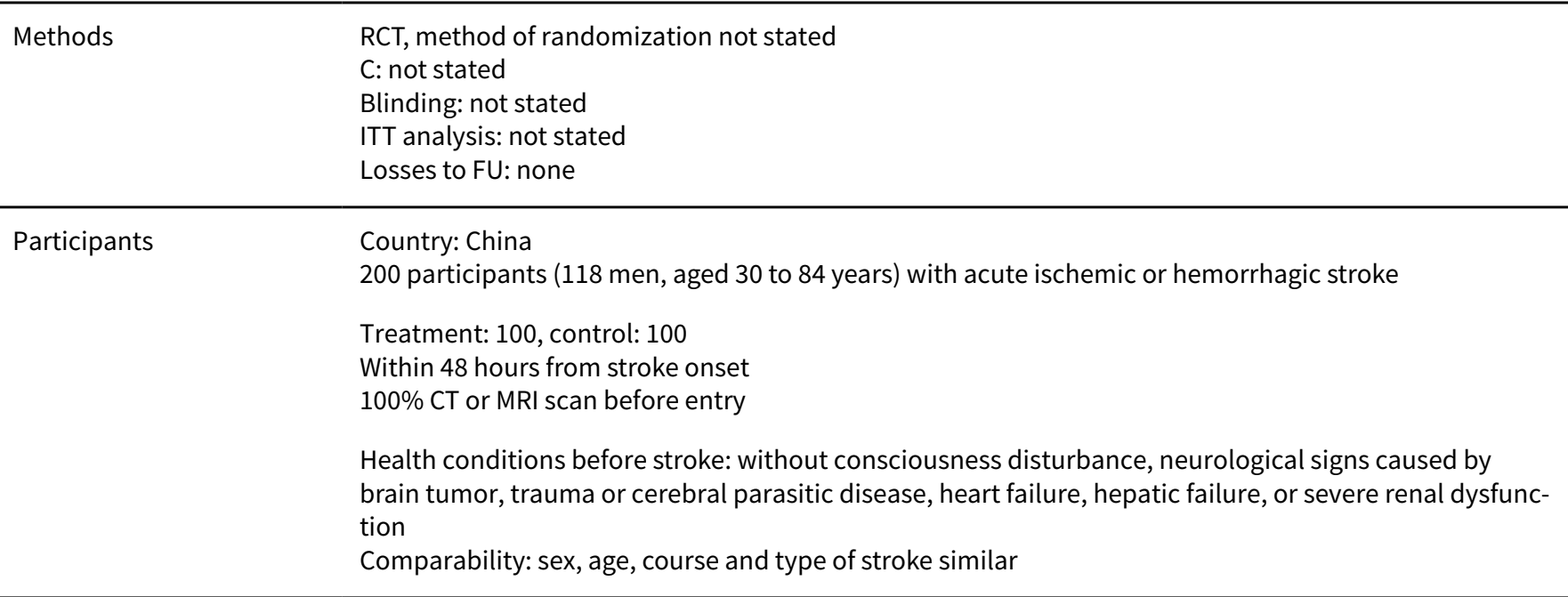


Chen 2015 (Continued)

Interventions

Treatment group: acupoints in upper and lower limbs including LI11, LI10, PC6, SJ5, SP6 etc., manual stimulation, 30 minutes/session, once a day for 30 days

Control group: no acupuncture

Both groups: routine rehabilitation therapy.

\begin{tabular}{ll}
\hline Outcomes & $\begin{array}{l}\text { FMA and BI evaluated before and after treatment } \\
\text { Presence of adverse events }\end{array}$ \\
\hline Notes & FU: 30 days
\end{tabular}

\section{Risk of bias}

\begin{tabular}{|c|c|c|}
\hline Bias & Authors' judgement & Support for judgement \\
\hline $\begin{array}{l}\text { Random sequence genera- } \\
\text { tion (selection bias) }\end{array}$ & Unclear risk & Insufficient information to permit judgement \\
\hline $\begin{array}{l}\text { Allocation concealment } \\
\text { (selection bias) }\end{array}$ & Unclear risk & Insufficient information to permit judgement \\
\hline $\begin{array}{l}\text { Blinding of participants } \\
\text { and personnel (perfor- } \\
\text { mance bias) } \\
\text { All outcomes }\end{array}$ & Unclear risk & Insufficient information to permit judgement \\
\hline $\begin{array}{l}\text { Blinding of outcome as- } \\
\text { sessment (detection bias) } \\
\text { All outcomes }\end{array}$ & Unclear risk & Insufficient information to permit judgement \\
\hline $\begin{array}{l}\text { Incomplete outcome data } \\
\text { (attrition bias) } \\
\text { All outcomes }\end{array}$ & Unclear risk & Insufficient information to permit judgement \\
\hline $\begin{array}{l}\text { Selective reporting (re- } \\
\text { porting bias) }\end{array}$ & Unclear risk & Insufficient information to permit judgement \\
\hline Other bias & Unclear risk & Insufficient information to permit judgement \\
\hline
\end{tabular}

\section{Chen 2016a}

Rethods
C: generated list of random numbers placed into sequentially numbered, opaque, sealed envelopes
Blinding: allopathic medical staff, rehabilitation therapists, outcome assessors, data analysts
ITT analysis: yes
Numbers with incomplete outcome data: 2 in acupuncture group and 3 in control group lost to fol-
low-up; 3 in acupuncture group and 1 in control group discontinued intervention

Country: China
250 participants (148 men, aged 35 to 80 years) with acute ischemic stroke
Treatment: 125 , control: 125
Between 2 and 7 days from stroke onset
CT or MRI scan before entry: not stated


Chen 2016a (Continued)

Health conditions before stroke: without serious heart, liver, or kidney-related disease; blood coagulation dysfunction; or congenital disabilities; for women, this study excluded those who were pregnant or breastfeeding

Comparability: sex, age, history of stroke, side of hemiparesis, NIHSS score at baseline and cognitive impairment similar

Interventions

Treatment group: 2 to 3 needles penetrated through the top midline, MS-6, MS- 7 of the lesion side for scalp acupuncture. Acupoints in upper and lower limbs included LI15, LI11, LI10, TE5, ST34, ST36, GB34, SP6, etc., manual stimulation, 30 minutes/session, 6 days per week for 3 weeks

Control group: no acupuncture

Both groups: conventional stroke rehabilitation care.

\begin{tabular}{ll}
\hline Outcomes & NIHSS and FMA evaluated at baseline, week 1, week 3, and week 7 \\
& Presence of adverse events \\
\hline Notes & FU: 7 weeks
\end{tabular}

\section{Risk of bias}

\begin{tabular}{|c|c|c|}
\hline Bias & Authors' judgement & Support for judgement \\
\hline $\begin{array}{l}\text { Random sequence genera- } \\
\text { tion (selection bias) }\end{array}$ & Low risk & $\begin{array}{l}\text { Randomization computer generated by independent research staff using soft- } \\
\text { ware }\end{array}$ \\
\hline $\begin{array}{l}\text { Allocation concealment } \\
\text { (selection bias) }\end{array}$ & Low risk & $\begin{array}{l}\text { Generated list of random numbers placed into sequentially numbered, } \\
\text { opaque, sealed envelopes }\end{array}$ \\
\hline $\begin{array}{l}\text { Blinding of participants } \\
\text { and personnel (perfor- } \\
\text { mance bias) } \\
\text { All outcomes }\end{array}$ & Unclear risk & Insufficient information to permit judgement \\
\hline $\begin{array}{l}\text { Blinding of outcome as- } \\
\text { sessment (detection bias) } \\
\text { All outcomes }\end{array}$ & Low risk & Blinding of outcome assessors \\
\hline $\begin{array}{l}\text { Incomplete outcome data } \\
\text { (attrition bias) } \\
\text { All outcomes }\end{array}$ & High risk & $\begin{array}{l}2 \text { in acupuncture group and } 3 \text { in control group lost to follow-up; } 3 \text { in acupunc- } \\
\text { ture group and } 1 \text { in control group discontinued intervention }\end{array}$ \\
\hline $\begin{array}{l}\text { Selective reporting (re- } \\
\text { porting bias) }\end{array}$ & Low risk & Outcomes in this trial in accordance with those in the protocol \\
\hline Other bias & Unclear risk & Insufficient information to permit judgement \\
\hline
\end{tabular}

Dong 2006

\begin{tabular}{ll}
\hline Methods & RCT, computer-generated randomization \\
& C: unclear \\
& Blinding: not stated \\
& ITT analysis: not stated \\
& Losses to FU: none \\
\hline Participants & Country: China \\
& 60 participants (35 men, aged 40 to 70 years) with acute hypertensive intracerebral hemorrhage \\
& Treatment: 30 , control: 30 \\
\hline
\end{tabular}


Dong 2006 (Continued)

Within 7 days from stroke onset

$100 \%$ CT scan

Health conditions before stroke: without serious heart, lung, liver, or kidney-related disease; coagulation-related intracerebral hemorrhage; subarachnoid hemorrhage; primary ventricular hemorrhage; mental disease

Comparability: hematoma volume and location similar in 2 groups

\begin{tabular}{ll}
\hline Interventions & $\begin{array}{l}\text { Treatment group: } 2 \text { acupoints (DU20, EX-HN5), manual twirling stimulation, } 30 \text { minutes/session, once a } \\
\text { day for } 28 \text { days } \\
\text { Control group: no acupuncture } \\
\text { Both groups: routine drug therapy }\end{array}$ \\
\hline Outcomes & Bl before and after treatment \\
Number of deaths
\end{tabular}

\section{Risk of bias}

\begin{tabular}{|c|c|c|}
\hline Bias & Authors' judgement & Support for judgement \\
\hline $\begin{array}{l}\text { Random sequence genera- } \\
\text { tion (selection bias) }\end{array}$ & Low risk & Computer-generated randomization \\
\hline $\begin{array}{l}\text { Allocation concealment } \\
\text { (selection bias) }\end{array}$ & Unclear risk & Insufficient information to permit judgement \\
\hline $\begin{array}{l}\text { Blinding of participants } \\
\text { and personnel (perfor- } \\
\text { mance bias) } \\
\text { All outcomes }\end{array}$ & Unclear risk & Insufficient information to permit judgement \\
\hline $\begin{array}{l}\text { Blinding of outcome as- } \\
\text { sessment (detection bias) } \\
\text { All outcomes }\end{array}$ & Unclear risk & Insufficient information to permit judgement \\
\hline $\begin{array}{l}\text { Incomplete outcome data } \\
\text { (attrition bias) } \\
\text { All outcomes }\end{array}$ & Unclear risk & Insufficient information to permit judgement \\
\hline $\begin{array}{l}\text { Selective reporting (re- } \\
\text { porting bias) }\end{array}$ & Unclear risk & Insufficient information to permit judgement \\
\hline Other bias & Unclear risk & Insufficient information to permit judgement \\
\hline
\end{tabular}

Duan 1997

$\begin{array}{ll}\text { Methods } & \text { RCT, method of randomization not stated } \\ \text { C: unclear } & \text { Blinding: not stated } \\ \text { ITT analysis: not stated } \\ \text { Losses to FU: none }\end{array}$


Duan 1997 (Continued)

Treatment: 47; control: 45

$100 \%$ CT scan before entry

Health conditions before stroke: not stated

Comparability: MESSS score and sites of infarction similar

\begin{tabular}{ll}
\hline Interventions & Treatment group: 2 acupoints (DU20, GB7), manual twirling stimulation, 24 minutes/session, once per \\
day for 30 days \\
Control group: no acupuncture \\
Both groups: routine drug therapy
\end{tabular}

\begin{tabular}{ll}
\hline Outcomes & $\begin{array}{l}\text { Change in MESSS score at } 30 \text { days } \\
\text { Number of participants with improvement (MESSS score decrease }>18 \% \text { ) at } 30 \text { days }\end{array}$ \\
\hline Notes & FU: 30 days \\
\hline
\end{tabular}

\section{Risk of bias}

\begin{tabular}{lll}
\hline Bias & Authors' judgement & Support for judgement \\
\hline $\begin{array}{l}\text { Random sequence genera- } \\
\text { tion (selection bias) }\end{array}$ & Unclear risk & Insufficient information to permit judgement \\
\hline $\begin{array}{l}\text { Allocation concealment } \\
\text { (selection bias) }\end{array}$ & Unclear risk & Insufficient information to permit judgement \\
\hline $\begin{array}{l}\text { Blinding of participants } \\
\text { and personnel (perfor- } \\
\text { mance bias) }\end{array}$ & Unclear risk & Insufficient information to permit judgement \\
$\begin{array}{l}\text { All outcomes } \\
\text { Blinding of outcome as- } \\
\text { sessment (detection bias) }\end{array}$ & Unclear risk & \\
All outcomes & & Insufficient information to permit judgement \\
\hline $\begin{array}{l}\text { Incomplete outcome data } \\
\text { (attrition bias) }\end{array}$ & Unclear risk & Insufficient information to permit judgement \\
\begin{tabular}{l} 
All outcomes \\
\hline $\begin{array}{l}\text { Selective reporting (re- } \\
\text { porting bias) }\end{array}$
\end{tabular} & Unclear risk & Insufficient information to permit judgement \\
\hline \begin{tabular}{l} 
Other bias \\
\hline
\end{tabular} & Unclear risk & Insufficient information to permit judgement \\
\hline
\end{tabular}

\section{Gosman-Hedstrom 1998}

RCthods computer-generated random number list stratified according to side of cerebral lesion, diabetes,
and hospital
C: central randomization by telephone
Blinding: participants and outcome assessors
ITT analysis: yes
Number of losses to FU: for BI, 1 in deep acupuncture group, 1 in superficial acupuncture group

$\begin{array}{ll}\text { Participants } & \text { Country: Sweden } \\ & 104 \text { participants ( } 46 \text { men, } \geq 40 \text { years) with acute ischemic stroke } \\ & \text { Treatment: } 37 \text {, control 1: } 34 \text {, control 2: } 33\end{array}$


Gosman-Hedstrom 1998 (Continued)

$$
\begin{aligned}
& <7 \text { days from stroke onset } \\
& 100 \% \text { CT scan before entry }
\end{aligned}
$$

Health conditions before stroke: without severe aphasia, unconsciousness, an earlier cerebral lesion (with a documented need of care), or treatment with a cardiac pacemaker

Comparability: no significant difference in age, neurological score, ADL, score past history

$\begin{array}{ll}\text { Interventions } & \text { Treatment group: } 10 \text { acupoints (DU20, LI11, ST38, EX mob, SJ5), manual or electrical stimulation, 30 } \\ \text { minutes/session, twice per week for 10 weeks } & \text { Control group 1: } 4 \text { short needles placed superficially just under the skin (1 in each extremity), no manu- } \\ \text { al or electrical stimulation } & \text { Control group 2: no acupuncture } \\ & 3 \text { groups: conventional stroke rehabilitation } \\ & \text { Change in SSS score at 3, 12 months } \\ \text { Change in BI at 3, 12 months } \\ \text { QOL score (NHP) at 3, 12 months } \\ \text { Number requiring institutional care at 3, 12 months } \\ \text { Adverse events }\end{array}$

\section{Risk of bias}

\begin{tabular}{|c|c|c|}
\hline $\begin{array}{l}\text { Blinding of outcome as- } \\
\text { sessment (detection bias) } \\
\text { All outcomes }\end{array}$ & Low risk & Blinding of outcome assessors \\
\hline $\begin{array}{l}\text { Incomplete outcome data } \\
\text { (attrition bias) } \\
\text { All outcomes }\end{array}$ & Low risk & $\begin{array}{l}\text { For } \mathrm{BI}, 1 \text { in deep acupuncture group and } 1 \text { in superficial acupuncture group } \\
\text { lost to follow-up }\end{array}$ \\
\hline $\begin{array}{l}\text { Selective reporting (re- } \\
\text { porting bias) }\end{array}$ & Unclear risk & Insufficient information to permit judgement \\
\hline Other bias & Unclear risk & Insufficient information to permit judgement \\
\hline
\end{tabular}

\begin{tabular}{lll}
\hline Bias & Authors' judgement & Support for judgement \\
\hline $\begin{array}{l}\text { Random sequence genera- } \\
\text { tion (selection bias) }\end{array}$ & Low risk & Computer-generated random number \\
\hline $\begin{array}{l}\text { Allocation concealment } \\
\text { (selection bias) }\end{array}$ & Low risk & Central randomization by telephone \\
\hline $\begin{array}{l}\text { Blinding of participants } \\
\text { and personnel (perfor- } \\
\text { mance bias) } \\
\text { All outcomes }\end{array}$ & Low risk & Blinding of participants \\
\hline
\end{tabular}

\section{Guo 2016}

$\begin{array}{ll}\text { Methods } & \text { RCT, simple randomization via coin tossing } \\ \text { C: } \text { not stated } & \text { Blinding: not stated } \\ \text { ITT analysis: not stated }\end{array}$


Guo 2016 (Continued)

Losses to FU: none

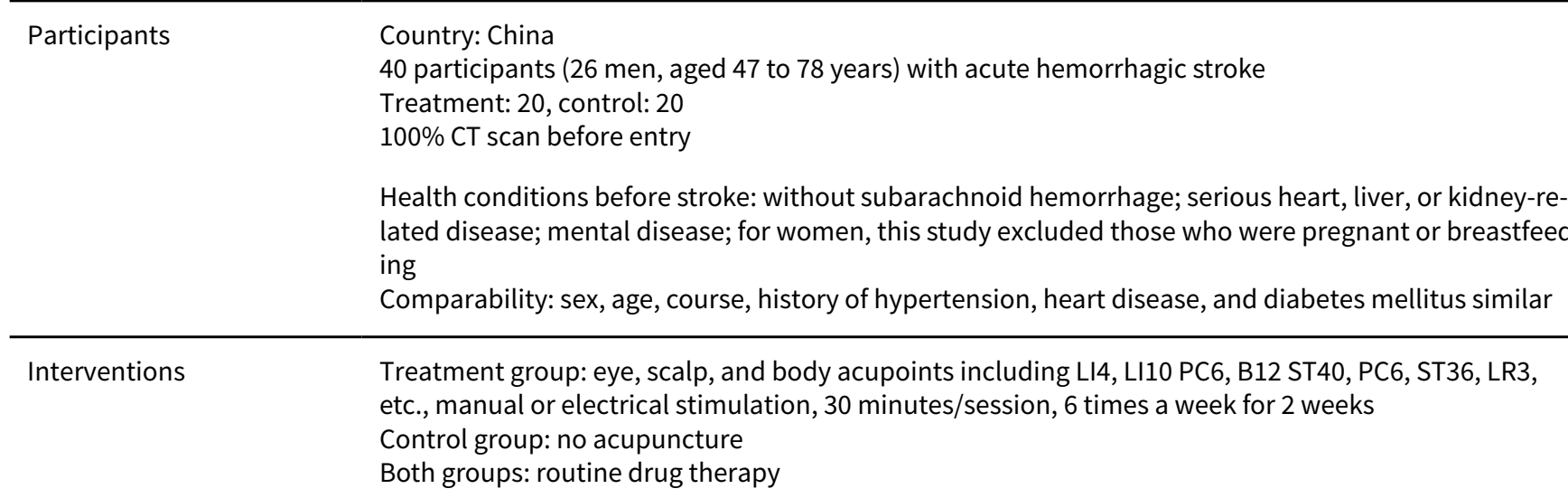

\begin{tabular}{ll}
\hline Outcomes & $\begin{array}{l}\text { Change in MESSS score before and after treatment } \\
\text { Numbers of adverse events and deaths }\end{array}$ \\
\hline Notes & FU: 14 days
\end{tabular}

\section{Risk of bias}

\begin{tabular}{|c|c|c|}
\hline Bias & Authors' judgement & Support for judgement \\
\hline $\begin{array}{l}\text { Random sequence genera- } \\
\text { tion (selection bias) }\end{array}$ & Low risk & Random sequence generated via simple randomization \\
\hline $\begin{array}{l}\text { Allocation concealment } \\
\text { (selection bias) }\end{array}$ & Unclear risk & Insufficient information to permit judgement \\
\hline $\begin{array}{l}\text { Blinding of participants } \\
\text { and personnel (perfor- } \\
\text { mance bias) } \\
\text { All outcomes }\end{array}$ & Unclear risk & Insufficient information to permit judgement \\
\hline $\begin{array}{l}\text { Blinding of outcome as- } \\
\text { sessment (detection bias) } \\
\text { All outcomes }\end{array}$ & Unclear risk & Insufficient information to permit judgement \\
\hline $\begin{array}{l}\text { Incomplete outcome data } \\
\text { (attrition bias) } \\
\text { All outcomes }\end{array}$ & Low risk & No participants withdrawn or lost to FU \\
\hline $\begin{array}{l}\text { Selective reporting (re- } \\
\text { porting bias) }\end{array}$ & Unclear risk & Insufficient information to permit judgement \\
\hline Other bias & Unclear risk & Insufficient information to permit judgement \\
\hline
\end{tabular}

\section{Hopwood 2008}

RCT, computer-generated random number list stratified with BI
C: sequentially numbered, sealed, opaque envelopes
Blinding: outcome assessors
ITT analysis: yes
Numbers of withdrawals: 10 in acupuncture group, 3 in control group


Hopwood 2008 (Continued)

Numbers of losses to FU: 2 in acupuncture group, 4 in control group

Country: UK
92 participants ( $42.8 \%$ male, age not reported) with acute ischemic stroke completed treatment.
Treatment: 47 , control: 45
Between 4 and 10 days from stroke onset
$50 \%$ CT scan before entry
Health conditions before stroke: without previous stroke or TIA, serious comorbidity, cardiac pacemak-
er
Comparability: age, SSS score, and BI similar

Interventions

Treatment group: 10 acupoints on paralyzed side, manual (GB20, GB31, GB43, etc.) or electrical stimulation (LI10, SJ5, GB34), 30 minutes/session, 3 times per week for 4 weeks

Control group: placebo acupuncture (deactivated TENS)

Both groups: drug therapy, routine physiotherapy, and occupational therapy

\begin{tabular}{ll}
\hline Outcomes & $\begin{array}{l}\text { Bl, Motricity Index, NHP at entry, 3, 6, 12, 24, and } 52 \text { weeks } \\
\text { Place of residence at } 24 \text { and } 52 \text { weeks }\end{array}$ \\
& Adverse events \\
\hline Notes & FU: 1 year
\end{tabular}

\section{Risk of bias}

\begin{tabular}{|c|c|c|}
\hline Bias & Authors' judgement & Support for judgement \\
\hline $\begin{array}{l}\text { Random sequence genera- } \\
\text { tion (selection bias) }\end{array}$ & Low risk & Computer-generated random number list stratified with $\mathrm{BI}$ \\
\hline $\begin{array}{l}\text { Allocation concealment } \\
\text { (selection bias) }\end{array}$ & Low risk & Sequentially numbered, sealed, opaque envelopes \\
\hline $\begin{array}{l}\text { Blinding of participants } \\
\text { and personnel (perfor- } \\
\text { mance bias) } \\
\text { All outcomes }\end{array}$ & High risk & Participants not blinded to treatment \\
\hline $\begin{array}{l}\text { Blinding of outcome as- } \\
\text { sessment (detection bias) } \\
\text { All outcomes }\end{array}$ & Low risk & Blinding of outcome assessors \\
\hline $\begin{array}{l}\text { Incomplete outcome data } \\
\text { (attrition bias) } \\
\text { All outcomes }\end{array}$ & Low risk & 13 in acupuncture group and 12 in control group lost to follow-up \\
\hline $\begin{array}{l}\text { Selective reporting (re- } \\
\text { porting bias) }\end{array}$ & Unclear risk & Insufficient information to permit judgement \\
\hline Other bias & Unclear risk & Insufficient information to permit judgement \\
\hline
\end{tabular}

Hsieh 2007

Methods

$\mathrm{RCT}$, stratified randomization with envelopes, following the principle of simple block randomization 
Hsieh 2007 (Continued)

C: concealed envelopes

Blinding: outcome assessor

ITT analysis: yes

Losses to FU: 5, 6, 8,10 participants (at 2 weeks, 4 weeks, 3 months, and 6 months, respectively) in acupuncture group, corresponding figures for control group 2, 3, 9, 11

Country: Taiwan, Republic of China
63 participants (35 men, aged 59 to 88 years) with first-ever ischemic stroke
Treatment: 30 , control: 33
Within 2 weeks from stroke onset
$100 \%$ CT/MRI scan before entry
Health conditions before stroke: without acute life-threatening illness, significant systemic disease, or
hemodynamic instability
Comparibility: age, education level, premorbid social activity, hypertension, diabetes mellitus, cardio-
vascular disease, total cholesterol level, triglyceride, and hemoglobin similar

Interventions Treatment group: 9 acupoints (GV20, bilateral GB20, and LI15, LI11, LI4, GB31, GB34, St36 on paralyzed side), electrical stimulation, 20 minutes/session, 2 courses per week, with a total of 8 sessions in 1 month

Control group: no acupuncture

Both groups: All underwent a conventional rehabilitation program. Drup therapy was allowed at discretion.

\begin{tabular}{ll}
\hline Outcomes & $\begin{array}{l}\text { Number requiring institutional care after discharge } \\
\text { Change in FMA at 2, } 4 \text { weeks and 3, } 6 \text { months after stroke }\end{array}$ \\
\hline Notes & FU: 6 months \\
\hline
\end{tabular}

\section{Risk of bias}

\begin{tabular}{|c|c|c|}
\hline Bias & Authors' judgement & Support for judgement \\
\hline $\begin{array}{l}\text { Random sequence genera- } \\
\text { tion (selection bias) }\end{array}$ & Low risk & $\begin{array}{l}\text { Stratified randomization with envelopes, following the principle of simple } \\
\text { block randomization }\end{array}$ \\
\hline $\begin{array}{l}\text { Allocation concealment } \\
\text { (selection bias) }\end{array}$ & Low risk & Concealed envelopes \\
\hline $\begin{array}{l}\text { Blinding of participants } \\
\text { and personnel (perfor- } \\
\text { mance bias) } \\
\text { All outcomes }\end{array}$ & Unclear risk & Insufficient information to permit judgement \\
\hline $\begin{array}{l}\text { Blinding of outcome as- } \\
\text { sessment (detection bias) } \\
\text { All outcomes }\end{array}$ & Low risk & Blinding of outcome assessor \\
\hline $\begin{array}{l}\text { Incomplete outcome data } \\
\text { (attrition bias) } \\
\text { All outcomes }\end{array}$ & High risk & $\begin{array}{l}5,6,8,10 \text { participants (at } 2 \text { weeks, } 4 \text { weeks, } 3 \text { months, and } 6 \text { months, respec- } \\
\text { tively) in acupuncture group, corresponding figures for control group 2, 3, 9, } 11 \\
\text { Rate of loss to FU over } 30 \%\end{array}$ \\
\hline $\begin{array}{l}\text { Selective reporting (re- } \\
\text { porting bias) }\end{array}$ & Unclear risk & Insufficient information to permit judgement \\
\hline Other bias & Unclear risk & Insufficient information to permit judgement \\
\hline
\end{tabular}


Hu 1993

$\begin{array}{ll}\text { Methods } & \text { RCT, methods of randomization not stated } \\ \text { C: unclear } \\ \text { Blinding: none } \\ \text { ITT analysis: not stated } \\ \text { Losses to FU: none }\end{array}$

\begin{tabular}{|c|c|}
\hline \multirow[t]{4}{*}{ Participants } & $\begin{array}{l}\text { Country: China (Taiwan) } \\
30 \text { participants ( } 28 \text { men, aged } 46 \text { to } 74 \text { years) with acute ischemic stroke }\end{array}$ \\
\hline & $\begin{array}{l}\text { Treatment: } 15 \text {, control: } 15 \\
<36 \text { hours from stroke onset } \\
100 \% \text { CT before entry }\end{array}$ \\
\hline & $\begin{array}{l}\text { Health conditions before stroke: without history of previous stroke, coma, any other acute life-threat- } \\
\text { ening disease, significant systemic disease, or anticoagulant therapy }\end{array}$ \\
\hline & $\begin{array}{l}\text { Comparability: age, sex, risk factors, and location of stroke similar, more hemispheric stroke and less } \\
\text { lacunar stroke in acupuncture group }\end{array}$ \\
\hline Interventions & $\begin{array}{l}\text { Treatment group: more than } 24 \text { acupoints (scalp motor area, GB21, LI11, GB34, EX-UE7, BL60, and } \\
\text { LR3 selected routinely), electrical stimulation }(9.4 \mathrm{~Hz}), 30 \text { to } 60 \text { minutes/session, every other day for } 4 \\
\text { weeks } \\
\text { Control group: no acupuncture } \\
\text { Both groups: supportive treatment, prevention of complications, and standard rehabilitation program }\end{array}$ \\
\hline Outcomes & $\begin{array}{l}\text { Change in SSS score at } 28,90 \text { days } \\
\text { Change in } \mathrm{BI} \text { at } 28,90 \text { days }\end{array}$ \\
\hline Notes & FU: 90 days \\
\hline
\end{tabular}

\section{Risk of bias}

Bias Authors' judgement Support for judgement

Random sequence genera- Unclear risk Insufficient information to permit judgement tion (selection bias)

\begin{tabular}{|c|c|c|}
\hline $\begin{array}{l}\text { Allocation concealment } \\
\text { (selection bias) }\end{array}$ & Unclear risk & Insufficient information to permit judgement \\
\hline $\begin{array}{l}\text { Blinding of participants } \\
\text { and personnel (perfor- } \\
\text { mance bias) } \\
\text { All outcomes }\end{array}$ & Unclear risk & Insufficient information to permit judgement \\
\hline $\begin{array}{l}\text { Blinding of outcome as- } \\
\text { sessment (detection bias) } \\
\text { All outcomes }\end{array}$ & Unclear risk & Insufficient information to permit judgement \\
\hline $\begin{array}{l}\text { Incomplete outcome data } \\
\text { (attrition bias) } \\
\text { All outcomes }\end{array}$ & Unclear risk & Insufficient information to permit judgement \\
\hline $\begin{array}{l}\text { Selective reporting (re- } \\
\text { porting bias) }\end{array}$ & Unclear risk & Insufficient information to permit judgement \\
\hline
\end{tabular}


Hu 1993 (Continued)

Other bias Unclear risk Insufficient information to permit judgement

Huang 2002

\begin{tabular}{|c|c|}
\hline Methods & $\begin{array}{l}\text { RCT, method of randomization not stated } \\
\text { C: unclear } \\
\text { Blinding: none } \\
\text { ITT analysis: not stated } \\
\text { Losses to FU: unclear }\end{array}$ \\
\hline Participants & $\begin{array}{l}\text { Country: China } \\
35 \text { participants (18 men, aged } 54 \text { to } 74 \text { years) with acute ischemic stroke } \\
\text { Treatment: } 20 \text {, control: } 15 \\
\leq 48 \text { hours from stroke onset } \\
100 \% \text { CT scan } \\
\text { Health conditions before stroke: without unconsciousness, peptic ulcer, infective endocarditis, atrial } \\
\text { fibrillation, or severe renal dysfunction } \\
\text { Comparability: no significant difference in MESSS score }\end{array}$ \\
\hline Interventions & $\begin{array}{l}\text { Treatment group: } 4 \text { to } 6 \text { acupoints, pricking blood therapy, once a day for } 7 \text { days } \\
\text { Control group: no acupuncture } \\
\text { Both groups: drug therapy including ligustrazine and dextran }\end{array}$ \\
\hline Outcomes & Change in MESSS score at 7 days \\
\hline Notes & FU: 7 days \\
\hline
\end{tabular}

\section{Risk of bias}

\begin{tabular}{lll}
\hline Bias & Authors' judgement & Support for judgement \\
\hline $\begin{array}{l}\text { Random sequence genera- } \\
\text { tion (selection bias) }\end{array}$ & Unclear risk & Insufficient information to permit judgement \\
\hline $\begin{array}{l}\text { Allocation concealment } \\
\text { (selection bias) }\end{array}$ & Unclear risk & Insufficient information to permit judgement \\
\hline $\begin{array}{l}\text { Blinding of participants } \\
\begin{array}{l}\text { and personnel (perfor- } \\
\text { mance bias) }\end{array}\end{array}$ & Unclear risk & Insufficient information to permit judgement \\
$\begin{array}{l}\text { All outcomes } \\
\text { Blinding of outcome as- } \\
\text { sessment (detection bias) } \\
\text { All outcomes }\end{array}$ & Unclear risk & Insufficient information to permit judgement \\
\hline $\begin{array}{l}\text { Incomplete outcome data } \\
\text { (attrition bias) } \\
\text { All outcomes }\end{array}$ & Unclear risk & Insufficient information to permit judgement \\
\hline $\begin{array}{l}\text { Selective reporting (re- } \\
\text { porting bias) }\end{array}$ & Unclear risk & Insufficient information to permit judgement \\
\hline \begin{tabular}{l} 
Other bias \\
\hline
\end{tabular} & Unclear risk & Insufficient information to permit judgement \\
\hline
\end{tabular}


Jin 1999

\begin{tabular}{|c|c|}
\hline Methods & $\begin{array}{l}\text { RCT, method of randomization not stated } \\
\text { Blinding: none } \\
\text { ITT analysis: not stated } \\
\text { Losses to FU: none }\end{array}$ \\
\hline \multirow[t]{4}{*}{ Participants } & $\begin{array}{l}\text { Country: China } \\
120 \text { participants ( } 74 \text { men, aged } 50 \text { to } 85 \text { years) with acute ischemic stroke }\end{array}$ \\
\hline & $\begin{array}{l}\text { Treatment: } 60 \text {, control: } 60 \\
<1 \text { month from stroke onset } \\
100 \% \text { CT scan before entry }\end{array}$ \\
\hline & Health conditions before stroke: not stated \\
\hline & Comparability: sex, age, past history, comorbidity, and stroke severity similar \\
\hline Interventions & $\begin{array}{l}\text { Treatment group: more than } 14 \text { acupoints (DU20, DU23, and DU26 selected routinely), manual twirling } \\
\text { or electrical stimulation, } 60 \text { minutes/session, } 5 \text { times a week for } 40 \text { days } \\
\text { Control group: no acupuncture } \\
\text { Both groups: routine drug therapy }\end{array}$ \\
\hline Outcomes & Number of participants with improvement (MESSS score decrease $>8$ ) at 40 days \\
\hline Notes & FU: 40 days \\
\hline
\end{tabular}

\section{Risk of bias}

\begin{tabular}{lll}
\hline Bias & Authors' judgement & Support for judgement \\
\hline $\begin{array}{l}\text { Random sequence genera- } \\
\text { tion (selection bias) }\end{array}$ & Unclear risk & Insufficient information to permit judgement \\
\hline $\begin{array}{l}\text { Allocation concealment } \\
\text { (selection bias) }\end{array}$ & Unclear risk & Insufficient information to permit judgement \\
\hline $\begin{array}{l}\text { Blinding of participants } \\
\text { and personnel (perfor- } \\
\text { mance bias) } \\
\text { All outcomes }\end{array}$ & Unclear risk & Insufficient information to permit judgement \\
\hline $\begin{array}{l}\text { Blinding of outcome as- } \\
\text { sessment (detection bias) } \\
\text { All outcomes }\end{array}$ & Unclear risk & \\
\hline $\begin{array}{l}\text { Incomplete outcome data } \\
\text { (attrition bias) } \\
\text { All outcomes }\end{array}$ & Unclear risk & Insufficient information to permit judgement \\
\hline $\begin{array}{l}\text { Selective reporting (re- } \\
\text { porting bias) }\end{array}$ & Unclear risk & Insufficient information to permit judgement \\
\hline \begin{tabular}{l} 
Other bias \\
\hline
\end{tabular} & Unclear risk & Insufficient information to permit judgement \\
\hline
\end{tabular}


Johansson 1993

\begin{tabular}{|c|c|}
\hline Methods & $\begin{array}{l}\text { RCT, stratified randomization with envelopes } \\
\text { C: sealed envelopes but not sequentially numbered or opaque } \\
\text { Blinding: none } \\
\text { ITT analysis: not stated } \\
\text { Losses to FU: none }\end{array}$ \\
\hline Participants & $\begin{array}{l}\text { Country: Sweden } \\
78 \text { participants ( } 42 \text { men, median } 76 \text { years) with acute stroke } \\
\text { Treatment: } 38 \text {, control: } 40 \\
<10 \text { days from stroke onset } \\
63 \% \text { CT scan before entry } \\
\text { Health conditions before stroke: without pacemaker treatments } \\
\text { Comparibility: age, sex, side of infarction, and neurological score similar }\end{array}$ \\
\hline Interventions & $\begin{array}{l}\text { Treatment group: } 10 \text { acupoints (DU20, ST40, ST36, GB34, LI4, LI11, SJ5, etc.), manual and electrical } \\
\text { stimulation, } 30 \text { minutes/session, twice a week for } 10 \text { weeks } \\
\text { Control group: no acupuncture } \\
\text { Both groups: standard stroke rehabilitation including daily physiotherapy and occupational therapy }\end{array}$ \\
\hline Outcomes & $\begin{array}{l}\text { Motor function score at } 1,3 \text { months } \\
\text { Number requiring institutional care at } 3,12 \text { months } \\
\text { Change in } \mathrm{Bl} \text { at } 3,12 \text { months } \\
\text { QOL score (NHP) at } 3,12 \text { months }\end{array}$ \\
\hline Notes & FU: 1 year \\
\hline
\end{tabular}

\section{Risk of bias}

\begin{tabular}{|c|c|c|}
\hline Bias & Authors' judgement & Support for judgement \\
\hline $\begin{array}{l}\text { Random sequence genera- } \\
\text { tion (selection bias) }\end{array}$ & Low risk & Stratified randomization with envelopes \\
\hline $\begin{array}{l}\text { Allocation concealment } \\
\text { (selection bias) }\end{array}$ & Low risk & Sealed envelopes but not sequentially numbered or opaque \\
\hline $\begin{array}{l}\text { Blinding of participants } \\
\text { and personnel (perfor- } \\
\text { mance bias) } \\
\text { All outcomes }\end{array}$ & Unclear risk & Insufficient information to permit judgement \\
\hline $\begin{array}{l}\text { Blinding of outcome as- } \\
\text { sessment (detection bias) } \\
\text { All outcomes }\end{array}$ & Unclear risk & Insufficient information to permit judgement \\
\hline $\begin{array}{l}\text { Incomplete outcome data } \\
\text { (attrition bias) } \\
\text { All outcomes }\end{array}$ & Unclear risk & Insufficient information to permit judgement \\
\hline $\begin{array}{l}\text { Selective reporting (re- } \\
\text { porting bias) }\end{array}$ & Unclear risk & Insufficient information to permit judgement \\
\hline Other bias & Unclear risk & Insufficient information to permit judgement \\
\hline
\end{tabular}


Johansson 2001

\begin{tabular}{ll}
\hline Methods & RCT, computer-generated randomization \\
C: sequentially numbered, sealed, opaque envelopes \\
Blinding: participants and outcome assessors \\
ITT analysis: yes \\
Losses to FU: for BI, 6 in acupuncture group, 6 in control group
\end{tabular}

Country: Sweden
99 participants ( 54 men, mean age $76 \pm 9$ years in treatment group, mean age $76 \pm 11$ years in control
group) with acute ischemic stroke
Treatment: 48 , control: 51
5 to 10 days from stroke onset
$98.5 \%$ CT scan before entry
Health conditions before stroke: without previous neurological, psychiatric, or other disorder, making
it difficult to pursue treatment or evaluation
Comparability: age, sex, medical history, CT scan finding, motor function score, and ability to walk 10
meters similar

Interventions Treatment group: 9 to 10 acupoints (LI4, ST36, DU20, LI11, ST40, EX28:21, EX36:1, GB34), manual and/or electrical stimulation, 30 minutes/session, twice a week for 10 weeks

Control group: acupoints as above, subliminal TENS (no skin sensation and no visible muscle contraction)

Both groups: conventional physiotherapy, occupational therapy, speech therapy, and drug therapy if needed

\begin{tabular}{ll}
\hline Outcomes & Motor function (RMI, walk speed, ability to walk 10 meters) at 3, 12 months \\
Change in $\mathrm{BI}$ at 3, 12 months \\
QOL score (NHP) at 3, 12 months \\
Adverse events
\end{tabular}

Notes FU: 1 year

\section{Risk of bias}

\begin{tabular}{lll}
\hline Bias & Authors' judgement & Support for judgement \\
\hline $\begin{array}{l}\text { Random sequence genera- } \\
\text { tion (selection bias) }\end{array}$ & Low risk & Computer-generated randomization \\
\hline $\begin{array}{l}\text { Allocation concealment } \\
\text { (selection bias) }\end{array}$ & Low risk & Sequentially numbered, sealed, opaque envelopes \\
\hline $\begin{array}{l}\text { Blinding of participants } \\
\text { and personnel (perfor- } \\
\text { mance bias) } \\
\text { All outcomes }\end{array}$ & Low risk & Blinding of participants \\
\hline
\end{tabular}

\begin{tabular}{ll}
\hline Blinding of outcome as- & Low risk \\
sessment (detection bias) & \\
All outcomes &
\end{tabular}

Incomplete outcome data Low risk $\quad$ For BI, 6 in acupuncture group, 6 in control group lost to follow-up
(attrition bias)
All outcomes

Selective reporting (re- Unclear risk Insufficient information to permit judgement
porting bias)


Johansson 2001 (Continued)

Other bias Unclear risk Insufficient information to permit judgement

Lin 2005

\begin{tabular}{|c|c|}
\hline Methods & $\begin{array}{l}\text { RCT, method of randomization not stated } \\
\text { C: unclear } \\
\text { Blinding: not stated } \\
\text { ITT analysis: not stated } \\
\text { Losses to FU: none }\end{array}$ \\
\hline Participants & $\begin{array}{l}\text { Country: China } \\
80 \text { acute participants ( } 41 \text { men, aged } 23 \text { to } 89 \text { years) with acute ischemic stroke } \\
\text { Treatment: } 40 \text {, control: } 40 \\
\text { Within } 3 \text { days from stroke onset } \\
\text { All had CT scan before entry. } \\
\text { Health conditions before stroke: not stated } \\
\text { Comparability: age, sex, complications, MESSS before treatment similar }\end{array}$ \\
\hline Interventions & $\begin{array}{l}\text { Treatment group: } 8 \text { acupoints (DU20, ST36, PC6, LI4, etc.), manual twirling stimulation, } 20 \text { minutes/ses- } \\
\text { sion, once a day for } 12 \text { days } \\
\text { Control group: no acupuncture } \\
\text { Both groups: routine drug therapy }\end{array}$ \\
\hline Outcomes & Change in MESSS at 12 days \\
\hline Notes & $\mathrm{J}: 12$ days \\
\hline
\end{tabular}

\section{Risk of bias}

\begin{tabular}{lll}
\hline Bias & Authors' judgement & Support for judgement \\
\hline $\begin{array}{l}\text { Random sequence genera- } \\
\text { tion (selection bias) }\end{array}$ & Unclear risk & Insufficient information to permit judgement \\
\hline $\begin{array}{l}\text { Allocation concealment } \\
\text { (selection bias) }\end{array}$ & Unclear risk & Insufficient information to permit judgement \\
\hline $\begin{array}{l}\text { Blinding of participants } \\
\text { and personnel (perfor- } \\
\text { mance bias) }\end{array}$ & Unclear risk & Insufficient information to permit judgement \\
\begin{tabular}{l} 
All outcomes \\
\hline
\end{tabular}
\end{tabular}

Blinding of outcome as- Unclear risk Insufficient information to permit judgement
sessment (detection bias)

All outcomes

\begin{tabular}{lll}
\hline $\begin{array}{l}\text { Incomplete outcome data } \\
\text { (attrition bias) } \\
\text { All outcomes }\end{array}$ & Unclear risk & Insufficient information to permit judgement \\
\hline $\begin{array}{l}\text { Selective reporting (re- } \\
\text { porting bias) }\end{array}$ & Unclear risk & Insufficient information to permit judgement \\
\hline Other bias & Unclear risk & Insufficient information to permit judgement \\
\hline
\end{tabular}


Liu 2016

Methods

$\mathrm{RCT}$, randomized via an online random number generator

C: generated code sealed in an envelope

Blinding: blinding of evaluator

ITT analysis: not stated

Numbers with incomplete outcome data: 2 in the acupuncture group, 5 in the control group

Country: Taiwan, Republic of China
38 participants ( 24 men, aged 40 to 85 years) with acute ischemic stroke
Treatment: 18 , control: 20
Within 3 days from stroke onset
All had CT scan before entry.
Health conditions before stroke: without a history of stroke or hemorrhage after ischemic stroke, cere-
bellar infarction, seizures, serious medical disease, cancer, or bleeding tendency; for women, this study
excluded those who were pregnant or breastfeeding
Comparability: age, sex, medical history, body mass index, drinking or smoking habits similar

Interventions Treatment group: 3 arm points, 3 leg points, 7 scalp points (LI11, TE5, LI4, ST36, SP6, LR3, etc.), manual twirling stimulation, 15 to 20 minutes/session, once a day for 2 weeks

Control group: no acupuncture

Both groups: routine standard treatment for ischemic stroke including thrombolytic therapy, antiplatelet treatment, anticoagulant therapy, and symptomatic treatment allowed at discretion

Changes in FMA and FIM at 4 weeks, as well as changes in NIHSS score, daily quality of life, and inde-
pendence at 12 weeks

Notes FU: 12 weeks

\section{Risk of bias}

\begin{tabular}{lll}
\hline Bias & Authors' judgement & Support for judgement \\
\hline $\begin{array}{l}\text { Random sequence genera- } \\
\text { tion (selection bias) }\end{array}$ & Low risk & Participants randomized via an online random number generator \\
\hline $\begin{array}{l}\text { Allocation concealment } \\
\text { (selection bias) }\end{array}$ & Low risk & Generated code sealed in an envelope \\
\hline
\end{tabular}

Blinding of participants Unclear risk Insufficient information to permit judgement
and personnel (perfor-

mance bias)

All outcomes

Blinding of outcome as- $\quad$ Low risk $\quad$ Blinding of assessors
sessment (detection bias)

\begin{tabular}{lll}
\hline $\begin{array}{l}\text { Incomplete outcome data } \\
\text { (attrition bias) } \\
\text { All outcomes }\end{array}$ & High risk & 7 of 38 participants did not complete the study. \\
\hline $\begin{array}{l}\text { Selective reporting (re- } \\
\text { porting bias) }\end{array}$ & Unclear risk & Insufficient information to permit judgement \\
\hline Other bias & Unclear risk & Insufficient information to permit judgement \\
\hline
\end{tabular}




\begin{tabular}{|c|c|}
\hline Methods & $\begin{array}{l}\text { RCT, method of randomization not stated } \\
\text { C: unclear } \\
\text { Blinding: unclear } \\
\text { ITT analysis: not stated } \\
\text { Losses to FU: none }\end{array}$ \\
\hline Participants & $\begin{array}{l}\text { Country: China. } \\
60 \text { participants ( } 40 \text { men, mean age } 69.5 \pm 7.1 \text { years in treatment group, mean age } 66.5 \pm 8.8 \text { years in con- } \\
\text { trol group) with acute ischemic stroke } \\
\text { Treatment: } 30 \text {, control: } 30 \\
2 \text { to } 14 \text { days from stroke onset } \\
100 \% \text { CT scan before entry } \\
\text { Health conditions before stroke: without liver or kidney-related disease, neurological signs caused by } \\
\text { brain tumor, trauma or cerebral parasitic disease, or mental disease } \\
\text { Comparability: age, sex, course, MESSS, medical history, and comorbidity similar }\end{array}$ \\
\hline Interventions & $\begin{array}{l}\text { Treatment group: } 3 \text { to } 5 \text { acupoints, manual twirling stimulation, treated for } 20 \text { days } \\
\text { Control group: no acupuncture } \\
\text { Both groups: routine drug therapy }\end{array}$ \\
\hline Outcomes & Change in MESSS at end of FU \\
\hline Notes & FU: 20 days \\
\hline
\end{tabular}

\section{Risk of bias}

\begin{tabular}{|c|c|c|}
\hline Bias & Authors' judgement & Support for judgement \\
\hline $\begin{array}{l}\text { Random sequence genera- } \\
\text { tion (selection bias) }\end{array}$ & Unclear risk & Insufficient information to permit judgement \\
\hline $\begin{array}{l}\text { Allocation concealment } \\
\text { (selection bias) }\end{array}$ & Unclear risk & Insufficient information to permit judgement \\
\hline $\begin{array}{l}\text { Blinding of participants } \\
\text { and personnel (perfor- } \\
\text { mance bias) } \\
\text { All outcomes }\end{array}$ & Unclear risk & Insufficient information to permit judgement \\
\hline $\begin{array}{l}\text { Blinding of outcome as- } \\
\text { sessment (detection bias) } \\
\text { All outcomes }\end{array}$ & Unclear risk & Insufficient information to permit judgement \\
\hline $\begin{array}{l}\text { Incomplete outcome data } \\
\text { (attrition bias) } \\
\text { All outcomes }\end{array}$ & Unclear risk & Insufficient information to permit judgement \\
\hline $\begin{array}{l}\text { Selective reporting (re- } \\
\text { porting bias) }\end{array}$ & Unclear risk & Insufficient information to permit judgement \\
\hline Other bias & Unclear risk & Insufficient information to permit judgement \\
\hline
\end{tabular}




\begin{tabular}{|c|c|}
\hline Methods & $\begin{array}{l}\text { RCT, method of randomization not stated } \\
\text { C: unclear } \\
\text { Blinding: not stated } \\
\text { ITT analysis: not stated } \\
\text { Losses to FU: none }\end{array}$ \\
\hline Participants & $\begin{array}{l}\text { Country: China } \\
105 \text { participants ( } 75 \text { men, aged } 21 \text { to } 76 \text { years) with acute ischemic stroke } \\
\text { Treatment: } 53 \text {, control: } 52 \\
\text { Within } 2 \text { weeks from stroke onset } \\
\text { 100\% CT/MRI scan before entry } \\
\text { Health conditions before stroke: without intracerebral hemorrhage; subarachnoid hemorrhage; histo- } \\
\text { ry of hypertension, diabetes mellitus, severe heart, liver, lung, or kidney-related disease or mental dis- } \\
\text { ease; women who were pregnant or breastfeeding excluded } \\
\text { Comparability: age, sex, and course similar }\end{array}$ \\
\hline Interventions & $\begin{array}{l}\text { Treatment group: scalp acupuncture (bilateral DU20 and GB7; EX-HN1 and GB6 at lesion side) and body } \\
\text { acupuncture (LI11, HT3, LI4, etc.), manual twirling stimulation, } 30 \text { minutes/session, once per day for } 14 \\
\text { days } \\
\text { Control group: no acupuncture } \\
\text { Both group: routine drug therapy }\end{array}$ \\
\hline Outcomes & Change in MESSS and FIM scores at end of follow-up \\
\hline Notes & U: 14 days \\
\hline
\end{tabular}

\section{Risk of bias}

\begin{tabular}{|c|c|c|}
\hline Bias & Authors' judgement & Support for judgement \\
\hline $\begin{array}{l}\text { Random sequence genera- } \\
\text { tion (selection bias) }\end{array}$ & Unclear risk & Insufficient information to permit judgement \\
\hline $\begin{array}{l}\text { Allocation concealment } \\
\text { (selection bias) }\end{array}$ & Unclear risk & Insufficient information to permit judgement \\
\hline $\begin{array}{l}\text { Blinding of participants } \\
\text { and personnel (perfor- } \\
\text { mance bias) } \\
\text { All outcomes }\end{array}$ & Unclear risk & Insufficient information to permit judgement \\
\hline $\begin{array}{l}\text { Blinding of outcome as- } \\
\text { sessment (detection bias) } \\
\text { All outcomes }\end{array}$ & Unclear risk & Insufficient information to permit judgement \\
\hline $\begin{array}{l}\text { Incomplete outcome data } \\
\text { (attrition bias) } \\
\text { All outcomes }\end{array}$ & Unclear risk & Insufficient information to permit judgement \\
\hline $\begin{array}{l}\text { Selective reporting (re- } \\
\text { porting bias) }\end{array}$ & Unclear risk & Insufficient information to permit judgement \\
\hline Other bias & Unclear risk & Insufficient information to permit judgement \\
\hline
\end{tabular}


Pang 2006

$\begin{array}{ll}\text { Methods } & \text { RCT, method of randomization not stated } \\ \text { C: unclear } \\ \text { Blinding: none } \\ \text { ITT analysis: not stated } \\ \text { Losses to FU: none }\end{array}$

\begin{tabular}{ll}
\hline Outcomes & Bl before and after treatment \\
\hline Notes & FU: mean 40 days \\
\hline
\end{tabular}

\section{Risk of bias}

\begin{tabular}{lll}
\hline Bias & Authors' judgement & Support for judgement \\
\hline $\begin{array}{l}\text { Random sequence genera- } \\
\text { tion (selection bias) }\end{array}$ & Unclear risk & Insufficient information to permit judgement \\
\hline $\begin{array}{l}\text { Allocation concealment } \\
\text { (selection bias) }\end{array}$ & Unclear risk & Insufficient information to permit judgement \\
\hline $\begin{array}{l}\text { Blinding of participants } \\
\text { and personnel (perfor- } \\
\text { mance bias) } \\
\text { All outcomes }\end{array}$ & Unclear risk & Insufficient information to permit judgement \\
\hline $\begin{array}{l}\text { Blinding of outcome as- } \\
\text { sessment (detection bias) }\end{array}$ & Unclear risk & \\
All outcomes & & Insufficient information to permit judgement \\
\hline $\begin{array}{l}\text { Incomplete outcome data } \\
\text { (attrition bias) } \\
\text { All outcomes }\end{array}$ & Unclear risk & Insufficient information to permit judgement \\
\hline $\begin{array}{l}\text { Selective reporting (re- } \\
\text { porting bias) }\end{array}$ & Unclear risk & Insufficient information to permit judgement \\
\hline \begin{tabular}{l} 
Other bias \\
\hline
\end{tabular} & Unclear risk & Insufficient information to permit judgement \\
\hline
\end{tabular}


Park 2005

$\begin{array}{ll}\text { Methods } & \text { RCT, stratified by baseline NIHSS score }<20 \text { or } \geq 20 \text {, age }<70 \text { years or } \geq 70 \text { years, and whether affected } \\ \text { side was dominant or non-dominant } \\ \text { C: block randomization by sequential, sealed, opaque envelopes } \\ \text { Blinding: participants and assessors } \\ \text { ITT analysis: not stated } \\ \text { Numbers of withdrawals: } 8 \text { in acupuncture group, } 10 \text { in control group } \\ \text { Country: England } \\ \text { Participants } \\ \text { control group) with acute ischemic or hemorrhagic stroke } \\ \text { Treatment: } 56 \text {, control: } 60 \\ \leq 4 \text { weeks from stroke onset } \\ \text { All had CT scan before entry. } \\ \text { Health conditions before stroke: without preexisting disability leading to modified Rankin score } \geq 3, \text { or } \\ \text { recent history of other serious diseases } \\ \text { Comparability: sex, age, previously disabled, dominance of affected side similar } \\ \text { Treatment group: } 10 \text { acupoints (BL66, LI1, HT3, HT4, GB43, etc.), manual stimulation, } \geq 20 \text { minutes/ses- } \\ \text { sion, received between } 9 \text { and } 12 \text { sessions of real acupuncture during } 2 \text { weeks } \\ \text { Control group: sham acupuncture (acupoints as above, giving the impression of insertion but without } \\ \text { penetrating the skin) } \\ \text { Both groups: conventional multi-disciplinary stroke rehabilitation }\end{array}$

\begin{tabular}{ll} 
Outcomes & Change in Barthel ADL score, NIHSS score, Motoricity Index at end of treatment \\
QOL score (EQ-5D and EQ-VAS) at end of treatment \\
Death \\
Adverse events \\
\hline Notes & FU: 2 weeks
\end{tabular}

\section{Risk of bias}

\begin{tabular}{lll}
\hline Bias & Authors' judgement & Support for judgement \\
\hline $\begin{array}{l}\text { Random sequence genera- } \\
\text { tion (selection bias) }\end{array}$ & Low risk & $\begin{array}{l}\text { Stratified by baseline NIHSS score }<20 \text { or } \geq 20, \text { age }<70 \text { years or } \geq 70 \text { years, and } \\
\text { whether affected side was dominant or non-dominant }\end{array}$ \\
\hline $\begin{array}{l}\text { Allocation concealment } \\
\text { (selection bias) }\end{array}$ & Low risk & Sequential, sealed, opaque envelopes \\
\hline $\begin{array}{l}\text { Blinding of participants } \\
\begin{array}{l}\text { and personnel (perfor- } \\
\text { mance bias) } \\
\text { All outcomes }\end{array}\end{array}$ & Low risk & Blinding of participants \\
\hline
\end{tabular}

\begin{tabular}{lll}
\hline $\begin{array}{l}\text { Blinding of outcome as- } \\
\text { sessment (detection bias) } \\
\text { All outcomes }\end{array}$ & Low risk & Blinding of outcome assessors \\
\hline $\begin{array}{l}\text { Incomplete outcome data } \\
\text { (attrition bias) }\end{array}$ & Low risk & 2 in acupuncture group and 0 in control group lost to follow-up \\
\hline
\end{tabular}


Park 2005 (Continued)

All outcomes

Selective reporting (re- Unclear risk Insufficient information to permit judgement
porting bias)

Other bias Unclear risk Insufficient information to permit judgement

Shen 2012a

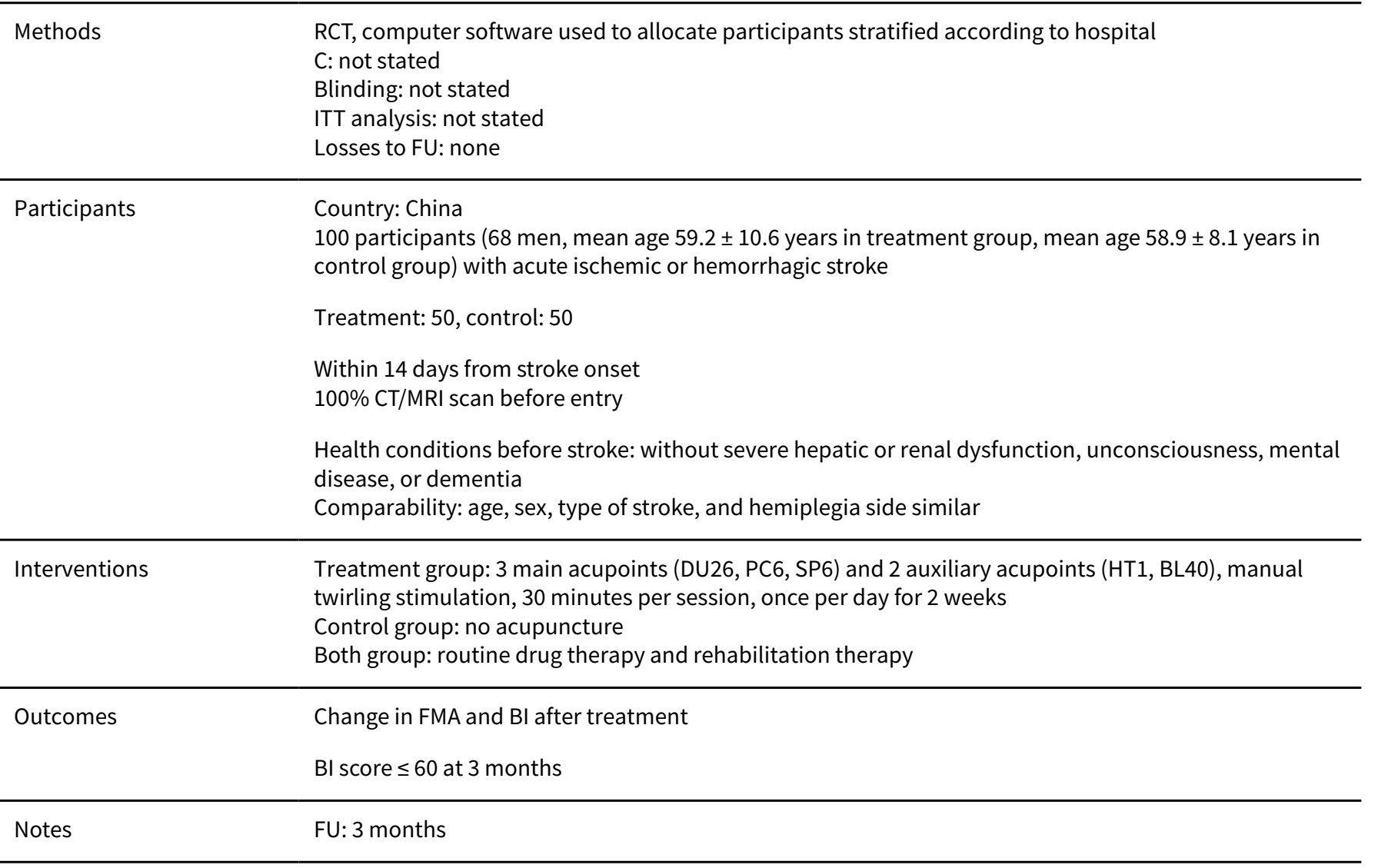

\section{Risk of bias}

\begin{tabular}{lll}
\hline Bias & Authors' judgement & Support for judgement \\
\hline $\begin{array}{l}\text { Random sequence genera- } \\
\text { tion (selection bias) }\end{array}$ & Low risk & $\begin{array}{l}\text { Computer software used to allocate participants stratified according to hospi- } \\
\text { tal }\end{array}$ \\
\hline $\begin{array}{l}\text { Allocation concealment } \\
\text { (selection bias) }\end{array}$ & Unclear risk & Insufficient information to permit judgement \\
\hline $\begin{array}{l}\text { Blinding of participants } \\
\text { and personnel (perfor- } \\
\text { mance bias) }\end{array}$ & Unclear risk & Insufficient information to permit judgement \\
$\begin{array}{l}\text { All outcomes } \\
\begin{array}{l}\text { Blinding of outcome as- } \\
\text { sessment (detection bias) } \\
\text { All outcomes }\end{array}\end{array}$ & Unclear risk & Insufficient information to permit judgement \\
\hline
\end{tabular}


Shen 2012a (Continued)
Incomplete outcome data
Unclear risk
Insufficient information to permit judgement
(attrition bias)

All outcomes

Selective reporting (re- Unclear risk Insufficient information to permit judgement
porting bias)

Other bias Unclear risk Insufficient information to permit judgement

Shen $2012 b$

$\begin{array}{ll}\text { Methods } & \text { RCT, computer-generated sequence } \\ \text { C: sealed envelopes } & \\ \text { Blinding: biostatistician and participants } \\ \text { ITT analysis: not stated } \\ \text { Number lost to follow-up: } 1 \text { in acupuncture group, } 2 \text { in control group }\end{array}$

\begin{tabular}{ll}
\hline Participants & Country: China \\
290 participants (98 men, mean age $60.24 \pm 9.30$ years in treatment group, mean age $61.41 \pm 9.82$ years \\
in control group) with acute ischemic stroke \\
Treatment: 145 , control: 145 \\
Within 14 days from stroke onset \\
$100 \%$ CT/MRI scan before entry \\
Health conditions before stroke: without history of rheumatoid arthritis or any other illness or injury \\
that could interfere with participation in the study \\
Comparability: age, sex, NIHSS score, and duration of symptoms similar between 2 groups \\
Treatment group: resuscitating acupuncture, 6 main acupoints (PC6, DU26, SP6, HT1, BL40, LU5) and \\
auxiliary acupoints according to clinical symptoms, manual twirling stimulation, 7 times a week for 4 \\
weeks \\
Control group: nearby acupoints of resuscitating acupuncture, manipulation as described above \\
Both groups: standard treatment including defibrase treatment, antiplatelet treatment, and sympto- \\
matic treatment allowed at discretion
\end{tabular}

NIHSS at 2, 4 weeks, CSS at 4 weeks, and SS-QOL at 6 months
BI, relapse, and death up to 6 months
Adverse events

Notes FU: 6 months

\section{Risk of bias}

Bias Authors' judgement Support for judgement

Random sequence genera- Low risk Computer-generated sequence
tion (selection bias)

Allocation concealment $\quad$ Low risk
(selection bias)


Shen 2012b (Continued)
Blinding of participants
Low risk
Blinding of participants and personnel (performance bias)

All outcomes

\begin{tabular}{lll}
\hline $\begin{array}{l}\text { Blinding of outcome as- } \\
\text { sessment (detection bias) } \\
\text { All outcomes }\end{array}$ & Unclear risk & Insufficient information to permit judgement \\
\hline $\begin{array}{l}\text { Incomplete outcome data } \\
\text { (attrition bias) } \\
\text { All outcomes }\end{array}$ & Low risk & 1 in acupuncture group and 2 in control group lost to follow-up \\
\hline $\begin{array}{l}\text { Selective reporting (re- } \\
\text { porting bias) }\end{array}$ & Unclear risk & Insufficient information to permit judgement \\
\hline \begin{tabular}{l} 
Other bias \\
\hline
\end{tabular} & Unclear risk & Insufficient information to permit judgement \\
\hline
\end{tabular}

Sze 2002

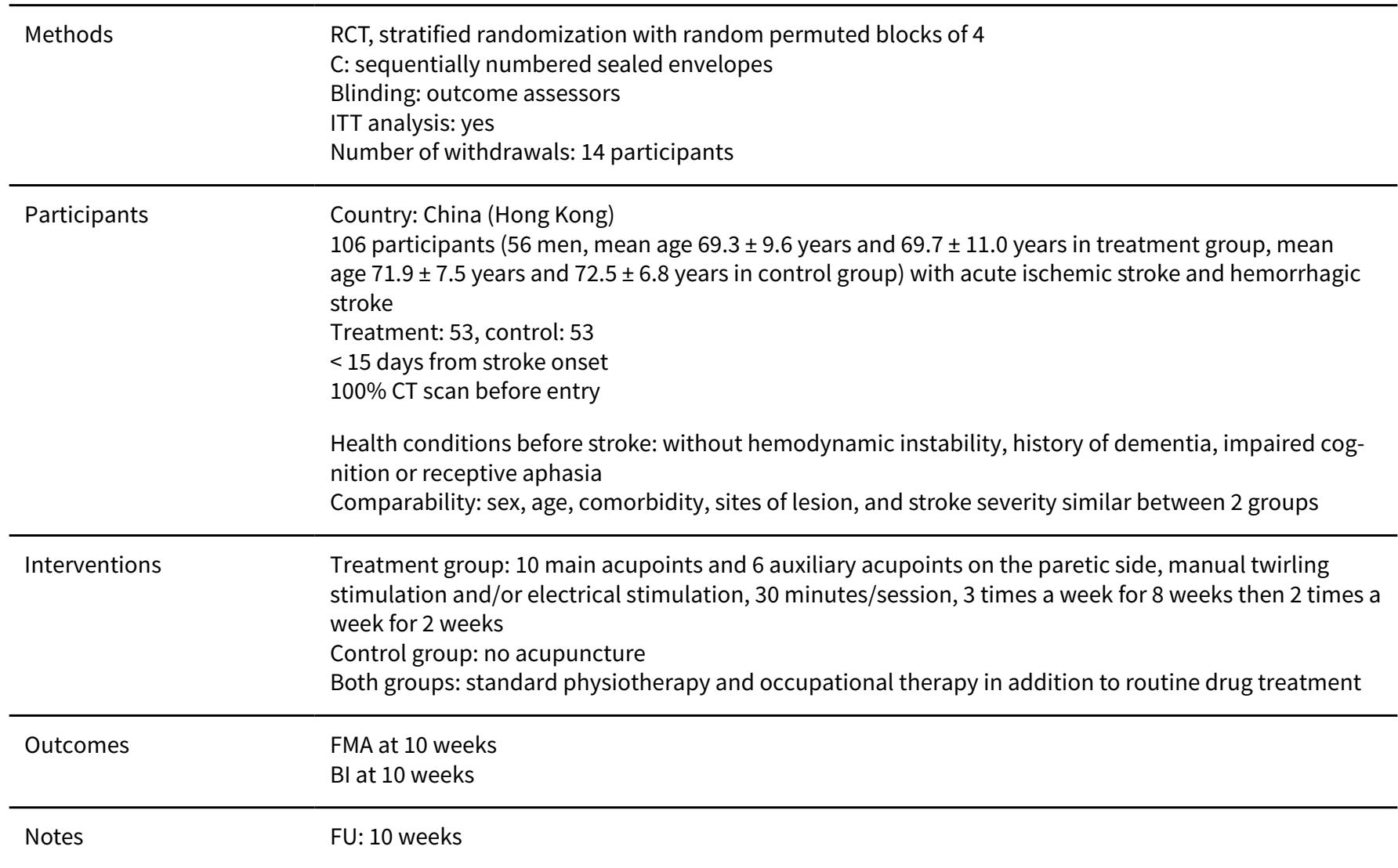

\section{Risk of bias}

\begin{tabular}{lll} 
Bias & Authors' judgement & Support for judgement \\
\hline $\begin{array}{l}\text { Random sequence genera- } \\
\text { tion (selection bias) }\end{array}$ & Low risk & Stratified randomization with random permuted blocks of 4 \\
\hline
\end{tabular}




\section{Sze 2002 (Continued)}

\begin{tabular}{l}
$\begin{array}{l}\text { Allocation concealment Low risk } \\
\text { (selection bias) }\end{array}$ \\
\hline
\end{tabular}

Blinding of participant

Unclear risk

Insufficient information to permit judgement

and personnel (perfor-

mance bias)

All outcomes

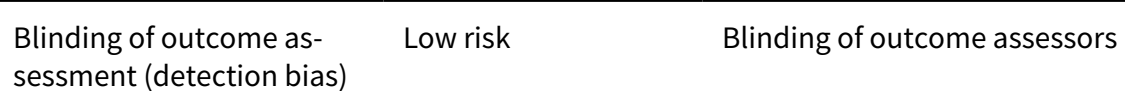

detection bias)

All outcomes

Incomplete outcome data Low risk 14 participants dropped out the trial.
(attrition bias)

All outcomes

Selective reporting (re- Unclear risk Insufficient information to permit judgement
porting bias)

porting bias)

Other bias Unclear risk Insufficient information to permit judgement

\section{Wang 2008}

\begin{tabular}{|c|c|}
\hline Methods & $\begin{array}{l}\text { RCT, method of randomization not stated } \\
\text { C: unclear } \\
\text { Blinding: not stated } \\
\text { ITT analysis: not stated } \\
\text { Losses to FU: none }\end{array}$ \\
\hline \multirow[t]{5}{*}{ Participants } & $\begin{array}{l}\text { Country: China } \\
120 \text { participants ( } 61 \text { men, aged } 41 \text { to } 70 \text { years) with acute ischemic stroke }\end{array}$ \\
\hline & Treatment: 60 , control: 60 \\
\hline & $\begin{array}{l}\text { Within } 7 \text { days from stroke onset } \\
100 \% \mathrm{CT} / \mathrm{MRI} \text { scan }\end{array}$ \\
\hline & $\begin{array}{l}\text { Health conditions before stroke: without severe heart, liver, or kidney-related disease; or bone-joint } \\
\text { diseases that influence recovery of motor function }\end{array}$ \\
\hline & Comparability: sex, age, course, and stroke severity similar \\
\hline Interventions & $\begin{array}{l}\text { Treatment group: } 2 \text { areas of main acupoints (upper energizer and lower energizer) and other areas of } \\
\text { auxiliary acupoints (hepatic area, cardiac area, renal area, gastric area, etc.) according to clinical symp- } \\
\text { toms, manual twirling stimulation, once a day for } 14 \text { days } \\
\text { Control group: no acupuncture } \\
\text { Both groups: routine drug therapy }\end{array}$ \\
\hline Outcomes & Change in MESSS at end of follow-up \\
\hline Notes & FU: 14 days \\
\hline
\end{tabular}

Risk of bias

Bias Authors' judgement Support for judgement


Wang 2008 (Continued)

Random sequence genera- Unclear risk Insufficient information to permit judgement tion (selection bias)

Allocation concealment $\quad$ Unclear risk
(selection bias)

(selection bias)

Blinding of participants Unclear risk Insufficient information to permit judgement
and personnel (perfor-
mance bias)
All outcomes

\begin{tabular}{ll}
\hline Blinding of outcome as- & Unclear risk
\end{tabular} Insufficient information to permit judgement

All outcomes

Incomplete outcome data Unclear risk Insufficient information to permit judgement

(attrition bias)

All outcomes

\begin{tabular}{lll}
\hline $\begin{array}{l}\text { Selective reporting (re- } \\
\text { porting bias) }\end{array}$ & Unclear risk & Insufficient information to permit judgement \\
\hline Other bias & Unclear risk & Insufficient information to permit judgement \\
\hline
\end{tabular}

\section{Wu 2002}

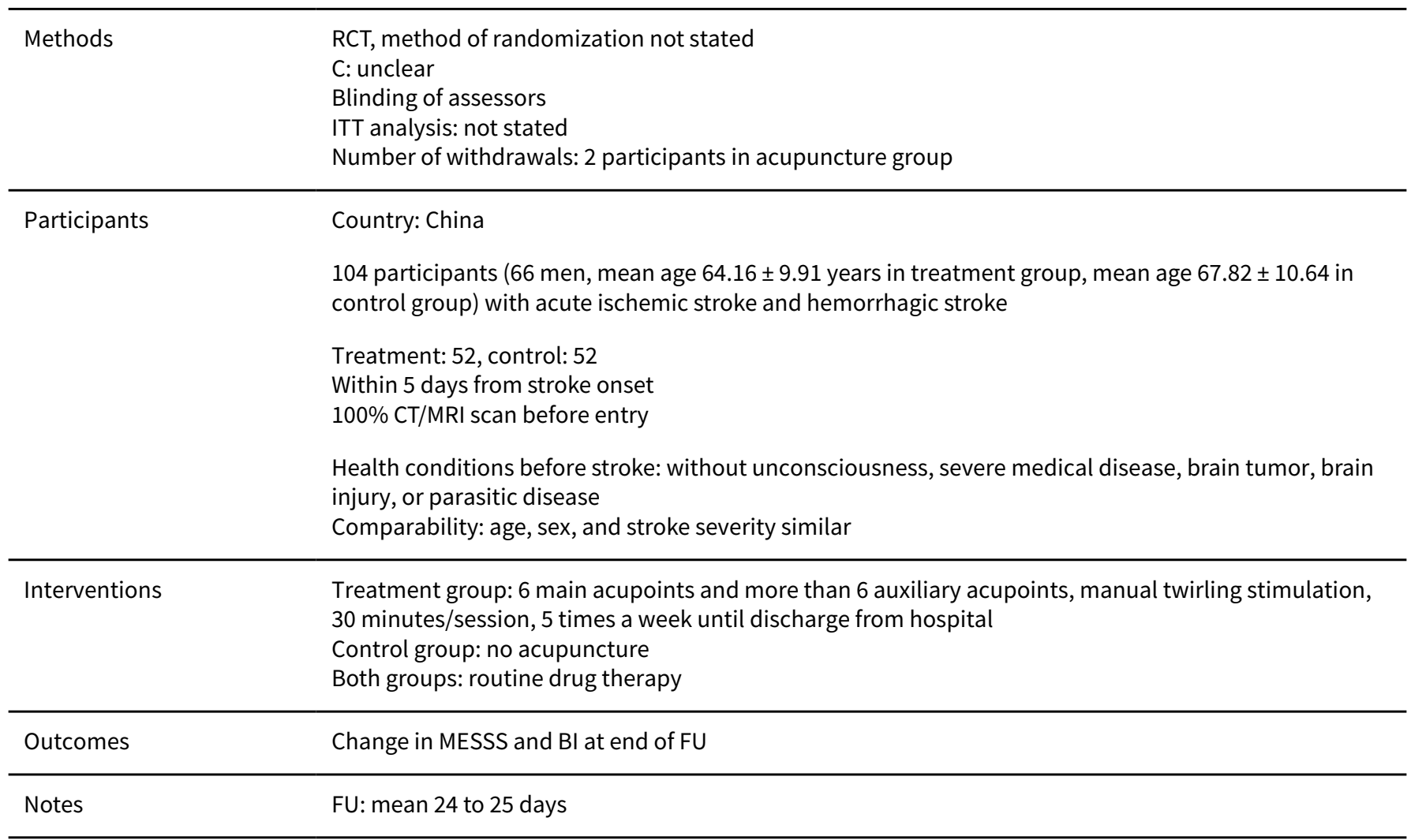

\section{Risk of bias}


Wu 2002 (Continued)

\begin{tabular}{lll} 
Bias & Authors' judgement & Support for judgement \\
\hline $\begin{array}{l}\text { Random sequence genera- } \\
\text { tion (selection bias) }\end{array}$ & Unclear risk & Insufficient information to permit judgement \\
\hline $\begin{array}{l}\text { Allocation concealment } \\
\text { (selection bias) }\end{array}$ & Unclear risk & Insufficient information to permit judgement \\
\hline $\begin{array}{l}\text { Blinding of participants } \\
\text { and personnel (perfor- } \\
\text { mance bias) }\end{array}$ & Unclear risk & Insufficient information to permit judgement \\
All outcomes & & \\
\hline
\end{tabular}

\begin{tabular}{|c|c|c|}
\hline $\begin{array}{l}\text { Blinding of outcome as- } \\
\text { sessment (detection bias) } \\
\text { All outcomes }\end{array}$ & Low risk & Blinding of assessors \\
\hline $\begin{array}{l}\text { Incomplete outcome data } \\
\text { (attrition bias) } \\
\text { All outcomes }\end{array}$ & Low risk & 2 participants in acupuncture group lost to follow-up \\
\hline $\begin{array}{l}\text { Selective reporting (re- } \\
\text { porting bias) }\end{array}$ & Unclear risk & Insufficient information to permit judgement \\
\hline Other bias & Unclear risk & Insufficient information to permit judgement \\
\hline
\end{tabular}

Yu 1993

\begin{tabular}{ll}
\hline Methods & RCT, with random number table \\
C: random number list read by doctor entering participants into trial & Blinding: none \\
ITT analysis: not stated \\
Losses to FU: none
\end{tabular}

Outcomes Change in mobility index at 15 days

\begin{tabular}{ll}
\hline Notes & FU: 15 days \\
\hline Risk of bias
\end{tabular}

\begin{tabular}{lll}
\hline Bias Authors' judgement & Support for judgement \\
\hline
\end{tabular}


Yu 1993 (Continued)

\begin{tabular}{lll}
$\begin{array}{l}\text { Random sequence genera- } \\
\text { tion (selection bias) }\end{array}$ & Low risk & Random number table \\
\hline $\begin{array}{l}\text { Allocation concealment } \\
\text { (selection bias) }\end{array}$ & Low risk & Random number list read by doctor entering participants into trial \\
\hline $\begin{array}{l}\text { Blinding of participants } \\
\text { and personnel (perfor- } \\
\begin{array}{l}\text { mance bias) } \\
\text { All outcomes }\end{array}\end{array}$ & Unclear risk & Insufficient information to permit judgement \\
\hline
\end{tabular}

\begin{tabular}{lll}
\hline $\begin{array}{l}\text { Blinding of outcome as- } \\
\text { sessment (detection bias) } \\
\text { All outcomes }\end{array}$ & Unclear risk & Insufficient information to permit judgement \\
\hline $\begin{array}{l}\text { Incomplete outcome data } \\
\begin{array}{l}\text { (attrition bias) } \\
\text { All outcomes }\end{array}\end{array}$ & Unclear risk & Insufficient information to permit judgement. \\
\hline $\begin{array}{l}\text { Selective reporting (re- } \\
\text { porting bias) }\end{array}$ & Unclear risk & Insufficient information to permit judgement \\
\hline Other bias & Unclear risk & Insufficient information to permit judgement \\
\hline
\end{tabular}

\section{Zhang 2005a}

\begin{tabular}{ll}
\hline Methods & RCT, computer-generated random number \\
C: sequentially numbered, sealed, opaque envelopes & Blinding: not stated \\
ITT analysis: not stated \\
Losses to FU: none
\end{tabular}

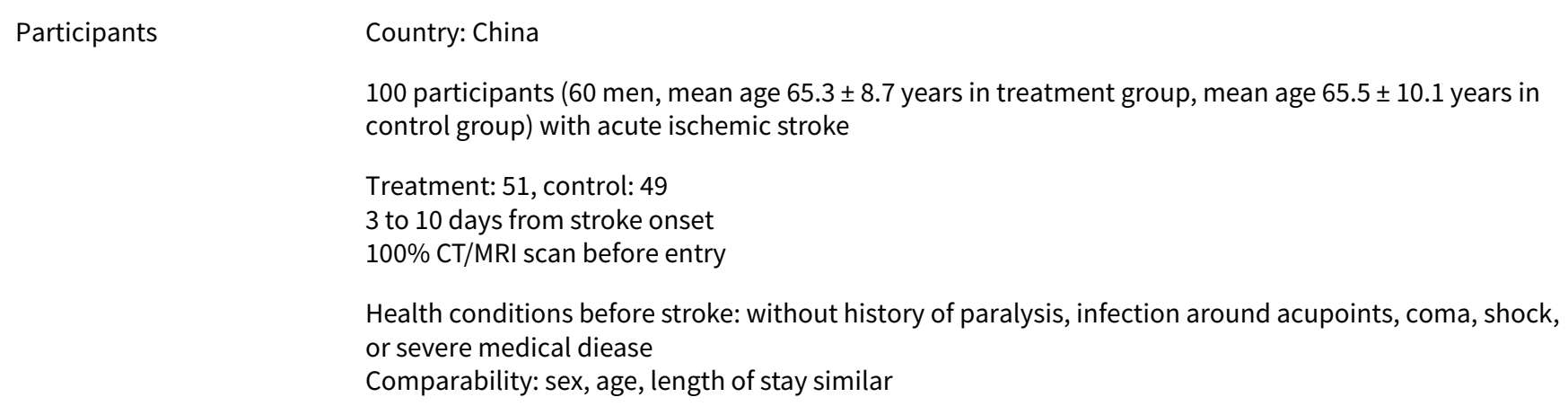

Health conditions before stroke: without history of paralysis, infection around acupoints, coma, shock, or severe medical diease

Comparability: sex, age, length of stay similar

\begin{tabular}{ll}
\hline Interventions & Treatment group: 4 main acupoints and more than 7 auxiliary acupoints, manual twirling stimulation, \\
& 30 minutes/session, 6 times a week for 3 weeks \\
Control group: no acupuncture & Both groups: routine drug therapy
\end{tabular}

Numbers of deaths or cases of dependency (trial authors' own definition) at 6 months
Numbers of deaths from all causes at 6 months
Adverse events


Zhang 2005a (Continued)
Notes
FU: 6 months

\section{Risk of bias}

\begin{tabular}{lll}
\hline Bias & Authors' judgement & Support for judgement \\
\hline $\begin{array}{l}\text { Random sequence genera- } \\
\text { tion (selection bias) }\end{array}$ & Low risk & Computer-generated random number \\
\hline $\begin{array}{l}\text { Allocation concealment } \\
\text { (selection bias) }\end{array}$ & Low risk & Sequentially numbered, sealed, opaque envelopes \\
\hline $\begin{array}{l}\text { Blinding of participants } \\
\text { and personnel (perfor- } \\
\text { mance bias) }\end{array}$ & Unclear risk & Insufficient information to permit judgement \\
$\begin{array}{l}\text { All outcomes } \\
\text { Blinding of outcome as- } \\
\text { sessment (detection bias) } \\
\text { All outcomes }\end{array}$ & Unclear risk & Insufficient information to permit judgement \\
\hline $\begin{array}{l}\text { Incomplete outcome data } \\
\text { (attrition bias) } \\
\text { All outcomes }\end{array}$ & Unclear risk & Insufficient information to permit judgement \\
\hline $\begin{array}{l}\text { Selective reporting (re- } \\
\text { porting bias) }\end{array}$ & Unclear risk & Insufficient information to permit judgement \\
\hline \begin{tabular}{l} 
Other bias \\
\hline
\end{tabular} & Unclear risk & Insufficient information to permit judgement \\
\hline
\end{tabular}

Zhang 2013

\begin{tabular}{|c|c|}
\hline Methods & $\begin{array}{l}\text { RCT, method of randomization not stated } \\
\text { C: unclear } \\
\text { Blinding: not stated } \\
\text { ITT analysis: not stated } \\
\text { Number of losses to follow-up: none }\end{array}$ \\
\hline Participants & $\begin{array}{l}\text { Country: China } \\
60 \text { participants ( } 36 \text { men, aged } 56 \text { to } 80 \text { years) with acute ischemic stroke } \\
\text { Treatment: } 30 \text {, control: } 30 \\
<3 \text { days from stroke onset } \\
100 \% \text { CT/MRI scan before entry } \\
\text { Health conditions before stroke: without cognitive decline, heart or lung failure, or limb fracture } \\
\text { Comparability: sex, age, and course similar between groups }\end{array}$ \\
\hline Interventions & $\begin{array}{l}\text { Treatment group: } 10 \text { to } 15 \text { acupoints (LI11, LI10, LU5, etc.), electrical stimulation, } 20 \text { minutes/session, } \\
\text { once a day for } 20 \text { days } \\
\text { Control group: no acupuncture } \\
\text { Both groups: drug therapy and rehabilitation treatment }\end{array}$ \\
\hline Outcomes & Change in FMA at end of follow-up \\
\hline Notes & FU: 20 days \\
\hline
\end{tabular}


Zhang 2013 (Continued)

Risk of bias

\begin{tabular}{|c|c|c|}
\hline Bias & Authors' judgement & Support for judgement \\
\hline $\begin{array}{l}\text { Random sequence genera- } \\
\text { tion (selection bias) }\end{array}$ & Unclear risk & Insufficient information to permit judgement \\
\hline $\begin{array}{l}\text { Allocation concealment } \\
\text { (selection bias) }\end{array}$ & Unclear risk & Insufficient information to permit judgement \\
\hline $\begin{array}{l}\text { Blinding of participants } \\
\text { and personnel (perfor- } \\
\text { mance bias) } \\
\text { All outcomes }\end{array}$ & Unclear risk & Insufficient information to permit judgement \\
\hline $\begin{array}{l}\text { Blinding of outcome as- } \\
\text { sessment (detection bias) } \\
\text { All outcomes }\end{array}$ & Unclear risk & Insufficient information to permit judgement \\
\hline $\begin{array}{l}\text { Incomplete outcome data } \\
\text { (attrition bias) } \\
\text { All outcomes }\end{array}$ & Unclear risk & Insufficient information to permit judgement \\
\hline $\begin{array}{l}\text { Selective reporting (re- } \\
\text { porting bias) }\end{array}$ & Unclear risk & Insufficient information to permit judgement \\
\hline Other bias & Unclear risk & Insufficient information to permit judgement \\
\hline
\end{tabular}

\section{Zhang 2015}

Methods

$\mathrm{RCT}$, centrally by computer-generated random numbers, stratified by participating centre

C: sequentially numbered, sealed opaque envelopes

Blinding: outcome assessors

ITT analysis: yes

Losses to FU: 40 (9.4\%) participants in acupuncture group, 39 (9.0\%) in control group at 6 months

Participants
$\begin{aligned} & \text { Country: China } \\ & \text { control group) with acute ischemic stroke }\end{aligned}$
Treatment: 427 , control: 435
Between 3 and 10 days from stroke onset
$100 \%$ CT/MRI scan before entry
Health conditions before stroke: without dependency in ADLs before present stroke, infection in
acupuncture sites, severe aphasia or unconsciousness, other severe complications or comorbidities
such as heart/renal function failure
Comparibility: age, sex, past medical history, neurological deficit, and lesion sites similar
Treatment group: 5 main acupoints (DU26 and PC6 at both sides, SP6 at paretic side) and 9 auxiliary
acupoints (DU20, ST36, ST40, LK3, LL5, etc.), manual and/or electrical stimulation, 30 minutes/session,
5 times per week for 3 to 4 weeks (in the pilot study) or 3 weeks (in the main study)
Control group: no acupuncture
Both groups: routine ischemic stroke treatment such as antithrombotic medications and prevention of
complications; rehabilitation also performed when available


Zhang 2015 (Continued)

Outcomes

Numbers of deaths/cases of disability according to BI at 6 months

Numbers of death/need for institutional care at 6 months

Case fatality and changes in neurological deficit score at end of treatment periods or at discharge

Severe adverse events and adverse events directly related to acupuncture

\begin{tabular}{|c|c|c|}
\hline Notes & FU: 6 months & \\
\hline \multicolumn{3}{|l|}{ Risk of bias } \\
\hline Bias & Authors' judgement & Support for judgement \\
\hline $\begin{array}{l}\text { Random sequence genera- } \\
\text { tion (selection bias) }\end{array}$ & Low risk & $\begin{array}{l}\text { Centrally by computer-generated random numbers, stratified by participating } \\
\text { center }\end{array}$ \\
\hline $\begin{array}{l}\text { Allocation concealment } \\
\text { (selection bias) }\end{array}$ & Low risk & Sequentially numbered, sealed opaque envelopes \\
\hline $\begin{array}{l}\text { Blinding of participants } \\
\text { and personnel (perfor- } \\
\text { mance bias) } \\
\text { All outcomes }\end{array}$ & Unclear risk & Insufficient information to permit judgement \\
\hline $\begin{array}{l}\text { Blinding of outcome as- } \\
\text { sessment (detection bias) } \\
\text { All outcomes }\end{array}$ & Low risk & Blinding of outcome assessors \\
\hline $\begin{array}{l}\text { Incomplete outcome data } \\
\text { (attrition bias) } \\
\text { All outcomes }\end{array}$ & Low risk & $\begin{array}{l}40(9.4 \%) \text { participants in acupuncture group and } 39(9.0 \%) \text { in control group at } \\
6 \text { months lost to follow-up }\end{array}$ \\
\hline $\begin{array}{l}\text { Selective reporting (re- } \\
\text { porting bias) }\end{array}$ & Low risk & Outcomes in this trial were in accordance with those in the protocol. \\
\hline Other bias & Unclear risk & Insufficient information to permit judgement \\
\hline
\end{tabular}

Zhu 2007

\begin{tabular}{ll}
\hline Methods & $\begin{array}{l}\text { RCT, method of randomization not stated } \\
\text { C: unclear } \\
\text { Blinding: none } \\
\text { ITT analysis: not stated } \\
\text { Losses to FU: none }\end{array}$ \\
\hline Participants & $\begin{array}{l}\text { Country: China } \\
\text { in control group) with acute ischemic stroke }\end{array}$ \\
& $\begin{array}{l}\text { Treatment: } 35, \text { control: } 35 \\
\text { Within } 7 \text { days from stroke onset } \\
100 \% \text { CT scan before entry }\end{array}$ \\
Health conditions before stroke: without severe medical disease such as heart/liver/renal function fail- $70.38 \pm 8.33$ years \\
ure \\
Comparability: age, sex similar
\end{tabular}


Zhu 2007 (Continued)

Interventions
Treatment group: 2 main acupoints (HT1, Ex-UE) and 2 auxiliary acupoints, electrical stimulation, 20 minutes/session, once a day for 30 days

Control group: no acupuncture

Both groups: routine drug therapy

\begin{tabular}{ll}
\hline Outcomes & Change in FMA at 30 days \\
\hline Notes & FU: 30 days
\end{tabular}

\section{Risk of bias}

\begin{tabular}{|c|c|c|}
\hline Bias & Authors' judgement & Support for judgement \\
\hline $\begin{array}{l}\text { Random sequence genera- } \\
\text { tion (selection bias) }\end{array}$ & Unclear risk & Insufficient information to permit judgement \\
\hline $\begin{array}{l}\text { Allocation concealment } \\
\text { (selection bias) }\end{array}$ & Unclear risk & Insufficient information to permit judgement \\
\hline $\begin{array}{l}\text { Blinding of participants } \\
\text { and personnel (perfor- } \\
\text { mance bias) } \\
\text { All outcomes }\end{array}$ & Unclear risk & Insufficient information to permit judgement \\
\hline $\begin{array}{l}\text { Blinding of outcome as- } \\
\text { sessment (detection bias) } \\
\text { All outcomes }\end{array}$ & Unclear risk & Insufficient information to permit judgement \\
\hline $\begin{array}{l}\text { Incomplete outcome data } \\
\text { (attrition bias) } \\
\text { All outcomes }\end{array}$ & Unclear risk & Insufficient information to permit judgement \\
\hline $\begin{array}{l}\text { Selective reporting (re- } \\
\text { porting bias) }\end{array}$ & Unclear risk & Insufficient information to permit judgement \\
\hline Other bias & Unclear risk & Insufficient information to permit judgement \\
\hline
\end{tabular}

acup: acupuncture.

ADL: activity of daily living.

BI: Barthel Index.

C: concealment of allocation.

CSS: Chinese Stroke Scale.

$\mathrm{CT}$ : computed tomography.

EQ-5D: EuroQoL-5-Dimensional forma.

EQ-VAS: EuroQoL-Visual Analog Scale.

FIM: Functional Independence Measurement.

FMA: Fugl-Meyer Assessment of Physical Performance.

fMRI: functional magnetic resonance imaging.

FU: follow-up.

ITT: intention-to-treat.

MESSS: modified Edinburgh-Scandinavian Stroke Scale.

MMSE: Mini Mental State Examination.

MRI: magnetic resonance imaging.

NHP: Nottingham Health Profile.

NIHSS: National Institutes of Health Stroke Scale.

QOL: quality of life.

$\mathrm{RCT}$ : randomized controlled trial.

RMI: Rivermead Mobility Index. 
SS-QOL: Stroke-Specific Quality of Life scale.

SSS: Scandinavian Stroke Scale.

TENS: transcutaneous electrical nerve stimulation.

TIA: transient ischemic attack.

Characteristics of excluded studies [ordered by study ID]

\begin{tabular}{ll}
\hline Study & Reason for exclusion \\
\hline Cai 2002a & $\begin{array}{l}\text { Questionable randomization (patients in } 5 \text { hospitals were included, but patients in only } 1 \text { hospital } \\
\text { were allocated into the control group) }\end{array}$ \\
\hline Fan 2014 & $\begin{array}{l}\text { It was not possible to include data from this trial in the analysis (NIHSS and BI were evaluated be- } \\
\text { fore and after treatment, but mean change in NIHSS and BI were not available). }\end{array}$ \\
\hline Fu 2001 & Data from this trial were questionable (data were inconsistent in full text of published paper). \\
\hline Gu 2005 & $\begin{array}{l}\text { It was not possible to include data from this trial in the analysis (BI was assessed before and after } \\
\text { treatment, but number of participants independent after treatment was not available). }\end{array}$ \\
\hline Guo 2006a & $\begin{array}{l}\text { It was not possible to include data from this trial in the analysis (MESSS was assessed before and } \\
\text { after treatment, but mean change in MESSS was not available). }\end{array}$ \\
\hline Guo 2006b & $\begin{array}{l}\text { Confounded trial (clinical treatment plus dynamic acupuncture vs clinical treatment plus tradition- } \\
\text { al acupuncture vs no acupuncture) }\end{array}$ \\
\hline
\end{tabular}

\begin{tabular}{ll} 
Han 2016 & Confounded to the course of included patients with stroke \\
\hline Jia 2007 & $\begin{array}{l}\text { It was not possible to include data from this trial in the analysis (BI was reported as mean } \pm \text { SD, so } \\
\text { data on death or dependency were not available). }\end{array}$
\end{tabular}

\begin{tabular}{|c|c|}
\hline Jiang 1998 & $\begin{array}{l}\text { It was not possible to include data from this trial in the analysis (see reason for exclusion of Guo } \\
\text { 2006a). }\end{array}$ \\
\hline Jiang 2009 & $\begin{array}{l}\text { Questionable inclusion criteria (> } 14 \text { days from stroke onset included); types of participants ques- } \\
\text { tionable }\end{array}$ \\
\hline Li 1989 & $\begin{array}{l}\text { Trial aimed to assess effects of } 2 \text { kinds of acupuncture on acute stroke (acupuncture involving Du15 } \\
\text { and Du16 in addition to other acupoints vs acupuncture involving other acupoints alone). }\end{array}$ \\
\hline Li 1999 & $\begin{array}{l}\text { It was not possible to include data from this trial in the analysis (see reason for exclusion of Guo } \\
2006 \text { a). }\end{array}$ \\
\hline Li 2000a & $\begin{array}{l}\text { It was not possible to include data from this trial in the analysis (see reason for exclusion of Guo } \\
2006 \text { a). }\end{array}$ \\
\hline Li 2000b & $\begin{array}{l}\text { It was not possible to include data from this trial in the analysis (see reason for exclusion of Guo } \\
\text { 2006a). }\end{array}$ \\
\hline Li 2001 & $\begin{array}{l}\text { It was not possible to include data from this trial in the analysis (see reason for exclusion of Guo } \\
\text { 2006a). }\end{array}$ \\
\hline Li 2008 & $\begin{array}{l}\text { Quasi-randomised trials. The scale used to evaluate neurological function did not include a de- } \\
\text { tailed description or reference, so reliability was uncertain. }\end{array}$ \\
\hline Li 2009 & $\begin{array}{l}\text { It was not possible to include data from this trial in the analysis (data on outcomes were not avail- } \\
\text { able). }\end{array}$ \\
\hline
\end{tabular}




\begin{tabular}{ll}
\hline Study & Reason for exclusion \\
\hline Liu 2001 & $\begin{array}{l}\text { It was not possible to include data from this trial in the analysis (see reason for exclusion of Guo } \\
\text { 2006a). }\end{array}$ \\
\hline Liu 2002a & $\begin{array}{l}\text { It was not possible to include data from this trial in the analysis. Motor function and BI were as- } \\
\text { sessed before and after treatment, but mean change in motor function score and number of partic- } \\
\text { ipants independent after treatment were not available. }\end{array}$
\end{tabular}

\begin{tabular}{ll}
\hline Liu 2002b & It was not possible to include data from this trial in the analysis. MESSS scores, motor function, and \\
BI were assessed before and after treatment, but mean change in neurological score and number \\
of participants independent after treatment were not available.
\end{tabular}

Liu 2003a It was not possible to include data from this trial in the analysis (see reason for exclusion of Guo
2006a).

Liu 2003b $\quad \begin{aligned} & \text { It was unclear when acupuncture treatment was started after stroke onset; types of participants } \\ & \text { were questionable. }\end{aligned}$

\begin{tabular}{l} 
Liu $2010 \quad \begin{array}{l}\text { It was not possible to include data from this trial in the analysis (see reason for exclusion of Guo } \\
\text { 2006a). }\end{array}$ \\
\hline
\end{tabular}

\begin{tabular}{ll}
\hline Liu 2015 & This trial did not define the course of acute stroke in inclusion criteria. \\
\hline Lv 2003 & $\begin{array}{l}\text { It was not possible to include data from this trial in the analysis. Motor function was assessed be- } \\
\text { fore and after treatment, but mean change in motor function score after treatment was not avail- } \\
\text { able. }\end{array}$
\end{tabular}

\begin{tabular}{|c|c|}
\hline Ma 1999 & $\begin{array}{l}\text { Confounded (acupuncture vs nimodipine), questionable randomization (68 cases in acupuncture } \\
\text { group and } 30 \text { cases in control group) }\end{array}$ \\
\hline Pei 2001 & $\begin{array}{l}\text { Confounded (clinical treatment plus electro-acupuncture vs clinical treatment plus active and/or } \\
\text { passive functional exercise) }\end{array}$ \\
\hline Ruan 2012 & $\begin{array}{l}\text { It was not possible to include data from this trial in the analysis (see reason for exclusion of Liu } \\
\text { 2015). }\end{array}$ \\
\hline Sang 2013 & $\begin{array}{l}\text { It was not possible to include data from this trial in the analysis (see reason for exclusion of Guo } \\
\text { 2006a). }\end{array}$ \\
\hline Si 1999 & Quasi-randomized trial \\
\hline Song 2016 & $\begin{array}{l}\text { Confounded (combined therapy of scalp cluster acupuncture and constraint-induced movement } \\
\text { therapy vs combined therapy of body acupuncture and traditional rehabilitation therapy) }\end{array}$ \\
\hline Tang 1996 & $\begin{array}{l}\text { It was not possible to include data from this trial in the analysis (see reason for exclusion of Guo } \\
\text { 2006a). }\end{array}$ \\
\hline Wang 2001 & $\begin{array}{l}\text { It was not possible to include data from this trial in the analysis. Neurological score was assessed } \\
\text { by a scoring system based on principles of Traditional Chinese Medicine, but mean change in score } \\
\text { after treatment was not available. }\end{array}$ \\
\hline Wang 2007 & $\begin{array}{l}\text { Questionable inclusion criteria (participants within } 3 \text { days after stroke onset were included in ab- } \\
\text { stract, and participants within } 7 \text { days were included in the main text; } 120 \text { participants were en- } \\
\text { rolled and randomized in this study in the main text, whereas only } 90 \text { participants were described } \\
\text { in the results section and no information was provided on the remaining } 30 \text { participants) }\end{array}$ \\
\hline
\end{tabular}




\begin{tabular}{ll}
\hline Study & Reason for exclusion \\
\hline Wang 2012a & $\begin{array}{l}\text { It was not possible to include data from this trial in the analysis (see reason for exclusion of Guo } \\
2006 a) .\end{array}$ \\
\hline Wang 2014 & $\begin{array}{l}\text { Lack of information on acupoints, how to stimulate, how long per session, and how many sessions. } \\
\text { In addition, it was not possible to obtain usable data for analysis. }\end{array}$
\end{tabular}

\begin{tabular}{|c|c|}
\hline Wang 2016 & $\begin{array}{l}\text { It was not possible to include data from this trial in the analysis (BI was evaluated before and after } \\
\text { treatment, but mean change in } \mathrm{BI} \text { was not available). }\end{array}$ \\
\hline Wong 1999 & Acupuncture points were stimulated by an adhesive surface electrode. \\
\hline Xia 2016 & This study included participants with subarachnoid hemorrhage. \\
\hline Xiong 2008 & $\begin{array}{l}\text { It was not possible to include data from this trial in the analysis (see reason for exclusion of Guo } \\
\text { 2006a). }\end{array}$ \\
\hline Xu 1997 & $\begin{array}{l}\text { It was not possible to include data from this trial in the analysis. BI was assessed before and after } \\
\text { treatment, but the number of participants independent at end of treatment was not available. }\end{array}$ \\
\hline Xu 2001 & $\begin{array}{l}\text { It was not possible to include data from this trial in the analysis. MESSS scores, motor function, and } \\
\text { BI were assessed before and after treatment, but mean change in neurological score and number } \\
\text { of participants independent after treatment were not available. }\end{array}$ \\
\hline Yang 2001 & $\begin{array}{l}\text { It was not possible to include data from this trial in the analysis (see reason for exclusion of Guo } \\
\text { 2006a). }\end{array}$ \\
\hline Yang 2011 & Quasi-randomized trial \\
\hline Yin 2013 & $\begin{array}{l}\text { Questionable randomization ( } 300 \text { cases were randomly divided into } 5 \text { groups: control, 24-hour } \\
\text { acupuncture, 72-hour acupuncture, 1-week acupuncture, and 2-week acupuncture from stroke on- } \\
\text { set) }\end{array}$ \\
\hline Yu 2003 & $\begin{array}{l}\text { Data in this trial were questionable. Participants with acute ischemic stroke and } \mathrm{BI}<70 \text { were in- } \\
\text { cluded and randomised in outpatient department. It was difficult to perform this trial in China, so } \\
\text { the type of study selected was questionable. }\end{array}$ \\
\hline Yun 2000 & Confounded: acupuncture plus defibrase $(5 \mathrm{U})$ vs defibrase (10 U) \\
\hline Zhang 1996 & $\begin{array}{l}\text { It was not possible to include data from this trial in the analysis (see reason for exclusion of Guo } \\
\text { 2006a). }\end{array}$ \\
\hline Zhang 1999 & $\begin{array}{l}\text { Questionable randomization ( } 145 \text { cases in acupuncture group and } 96 \text { cases in control group) and } \\
\text { no useful data available for analysis }\end{array}$ \\
\hline Zhang 2011 & $\begin{array}{l}\text { It was not possible to include data from this trial in the analysis (FMA was evaluated before and af- } \\
\text { ter treatment, but mean change in FMA score was not available). }\end{array}$ \\
\hline Zhao 2000 & $\begin{array}{l}\text { It was not possible to include data from this trial in the analysis (see reason for exclusion of Guo } \\
\text { 2006a). }\end{array}$ \\
\hline Zhen 2011 & $\begin{array}{l}\text { It was not possible to include data from this trial in the analysis ( } \mathrm{BI} \text { and FMA were evaluated before } \\
\text { and after treatment, but mean changes in } \mathrm{BI} \text { and FMA were not available). }\end{array}$ \\
\hline Zheng 1996 & $\begin{array}{l}\text { Confounded (acupuncture vs routine drug treatment); questionable quasi-randomization via alter- } \\
\text { nate allocation }(40 / 30)\end{array}$ \\
\hline
\end{tabular}




\begin{tabular}{ll}
\hline Study & Reason for exclusion \\
\hline Zhou 2000 & $\begin{array}{l}\text { It was not possible to include data from this trial in the analysis (see reason for exclusion of Guo } \\
2006 a) .\end{array}$ \\
\hline Zhou 2002 & $\begin{array}{l}\text { It was not possible to include data from this trial in the analysis. Motor function of limbs was as- } \\
\text { sessed via Yishangtian Scale, but mean changes in scores for each group were not available. }\end{array}$ \\
\hline Ihu 2012 & It was not possible to include data from this trial in the analysis (see reason for exclusion of Liu \\
\hline Zhu 2013 & It was not possible to include data from this trial in the analysis (see reason for exclusion of Zhen
\end{tabular}

BI: Barthel Index.

FMA: Fugl-Meyer Assessment of Physical Performance.

MESSS: modified Edinburgh-Scandinavian Stroke Scale.

NIHSS: National Institutes of Health Stroke Scale.

SD: standard deviation.

Characteristics of ongoing studies [ordered by study ID]

Chen 2014

\begin{tabular}{|c|c|}
\hline Trial name or title & Acupuncture for acute stroke: study protocol for a multicenter, randomized, controlled trial \\
\hline Methods & $\begin{array}{l}\text { RCT, computer-generated by independent research staff using software } \\
\text { C: sealed opaque envelopes } \\
\text { Blinding: outcome assessors }\end{array}$ \\
\hline Participants & $\begin{array}{l}\text { Country: China } \\
250 \text { participants with ischemic stroke } \\
<7 \text { days from stroke onset }\end{array}$ \\
\hline Interventions & $\begin{array}{l}\text { Treatment group: scalp acupuncture and electro-acupuncture, manual twirling stimulation and } \\
\text { electrical stimulation, } 30 \text { minutes per session, } 6 \text { times per week for } 3 \text { weeks } \\
\text { Control group: no acupuncture } \\
\text { Both groups: conventional stroke rehabilitation care }\end{array}$ \\
\hline Outcomes & $\begin{array}{l}\text { Changes in NIHSS score at the 1, 3, 4-week follow-up } \\
\text { FMA, MMSE, Montreal Cognitive Assessment } \\
\text { Videofluoroscopic swallowing study for swallowing ability } \\
\text { Incidence of adverse events }\end{array}$ \\
\hline Starting date & Started March 1, 2012 \\
\hline Contact information & $\begin{array}{l}\text { Correspondence: fangjianqiao7532@163.com, Department of Acupuncture, The Third Affiliated } \\
\text { Hospital of Zhejiang Chinese Medical University, No. } 219 \text { Moganshan Road, XiHu District, Hangzhou, } \\
\text { Zhejiang Province 310005, China }\end{array}$ \\
\hline Notes & FU: 4 weeks after treatment \\
\hline
\end{tabular}


Chen 2016b

Trial name or title

\section{Methods}

Methods

\begin{tabular}{ll}
\hline Methods & $\begin{array}{l}\text { RCT: computer generated by independent research staff using SAS 9.3 software } \\
\text { C: Generated list of random numbers to be placed into sequentially numbered, opaque, sealed en- } \\
\text { velopes } \\
\text { Blinding: rehabilitation therapists, participants, outcome assessors, and data analysts }\end{array}$ \\
\hline Participants & $\begin{array}{l}\text { Country: China } \\
120 \text { participants with ischemic stroke } \\
\text { Within } 1 \text { month from stroke onset }\end{array}$ \\
\hline Interventions & $\begin{array}{l}\text { Treatment group: motor area and sensory area of the lesion side for scalp acupuncture; IL15, LI11, } \\
\text { ST31, GB34, etc., for body acupuncture; CV12, CV10, etc., for abdominal acupuncture; manual stim- } \\
\text { ulation, } 30 \text { minutes per session, } 3 \text { times per week for } 8 \text { weeks } \\
\text { Control group: sham acupuncture, superficial needle insertion and minimal stimulation at the } \\
\text { non-acupoint and in non-meridian areas } \\
\text { Both groups: conventional stroke rehabilitation treatment and care }\end{array}$ \\
\hline
\end{tabular}

Acupuncture treatment for ischemic stroke in young adults: protocol for a randomized, sham-controlled clinical trial

\begin{tabular}{ll}
\hline Outcomes & BI, FMA, and QOL at week 9 and week 20 \\
& $\begin{array}{l}\text { Incidence of adverse events, mortality and recurrence rates, and QOL at } 10 \text { years, 30 years after } \\
\text { stroke }\end{array}$ \\
\hline Starting date & Not stated \\
\hline Contact information & $\begin{array}{l}\text { Correspondence to Professor Jianqiao Fang, Department of Acupuncture and Moxibustion, The } \\
\text { Third Affiliated Hospital of Zhejiang Chinese Medical University, Hangzhou City, Zhejiang Province, } \\
\text { China; fangjianqiao7532@163.com }\end{array}$ \\
\hline Notes & FU: 30 years \\
\hline
\end{tabular}

\section{Wang 2017a}

\begin{tabular}{|c|c|}
\hline Trial name or title & Acupuncture for acute moderate thalamic hemorrhage: randomized controlled trial protocol \\
\hline \multirow[t]{2}{*}{ Methods } & RCT: computer generated via Package for Encyclopaedia Medical Statistics 3.1 (PEMS 3.1) software \\
\hline & $\begin{array}{l}\text { C: generated list of random numbers to be placed into opaque sealed envelopes } \\
\text { Blinding: participants and assessors }\end{array}$ \\
\hline \multirow[t]{3}{*}{ Participants } & Country: China \\
\hline & 488 participants with thalamic hemorrhage \\
\hline & Within 72 hours from stroke onset \\
\hline \multirow[t]{3}{*}{ Interventions } & $\begin{array}{l}\text { Treatment group: scalp and body acupuncture (LI15, LI11, SJ5, LI4, ST34, ST36, etc.), manual stimu- } \\
\text { lation, } 30 \text { minutes per session, once a day, } 6 \text { times per week for } 6 \text { weeks }\end{array}$ \\
\hline & Control group: no acupuncture \\
\hline & $\begin{array}{l}\text { Both groups: conventional Western medical treatments as recommended by guidelines for the } \\
\text { management of spontaneous intracerebral hemorrhage }\end{array}$ \\
\hline \multirow[t]{2}{*}{ Outcomes } & Change in NIHSS score at 30 and 90 days \\
\hline & $\begin{array}{l}\text { Death or major disability at } 90 \text { days, need for surgery at } 30 \text { days, Glasgow Outcome Scale score at } \\
90 \text { days after thalamic hemorrhage }\end{array}$ \\
\hline
\end{tabular}


Wang 2017a (Continued)
Starting date
January 2017

Contact information

Correspondence: zhenjiuhuaxi@163.com. Department of Integrated Traditional and Western Medicine, West China Hospital, Sichuan University, Chengdu, China

Notes $\quad$ FU: 90 days

BI: Barthel Index.

C: concealment of allocation.

FMA: Fugl-Meyer Assessment of Physical Performance.

FU: follow-up.

MMSE: Mini Mental State Examination.

NIHSS: National Institutes of Health Stroke Scale.

QOL: quality of life.

$\mathrm{RCT}$ : randomized controlled trial.

\section{DATA AND ANALYSES}

Comparison 1. Acupuncture versus control

\begin{tabular}{|c|c|c|c|c|}
\hline Outcome or subgroup title & No. of studies & $\begin{array}{l}\text { No. of partici- } \\
\text { pants }\end{array}$ & Statistical method & Effect size \\
\hline $\begin{array}{l}1 \text { Death or dependency at end of fol- } \\
\text { low-up }\end{array}$ & 11 & 1582 & $\begin{array}{l}\text { Odds Ratio (M-H, Random, } \\
95 \% \mathrm{Cl})\end{array}$ & $0.61[0.46,0.79]$ \\
\hline $\begin{array}{l}1.1 \text { Acupuncture vs sham acupunc- } \\
\text { ture }\end{array}$ & 4 & 262 & $\begin{array}{l}\text { Odds Ratio (M-H, Random, } \\
95 \% \mathrm{Cl})\end{array}$ & $0.71[0.43,1.18]$ \\
\hline 1.2 Acupuncture vs open control & 8 & 1320 & $\begin{array}{l}\text { Odds Ratio (M-H, Random, } \\
95 \% \mathrm{Cl})\end{array}$ & $0.55[0.37,0.80]$ \\
\hline $\begin{array}{l}2 \text { Death or dependency at end of fol- } \\
\text { low-up (> } 3 \text { months) }\end{array}$ & 8 & 1436 & $\begin{array}{l}\text { Odds Ratio (M-H, Random, } \\
95 \% \mathrm{Cl})\end{array}$ & $0.67[0.53,0.85]$ \\
\hline $\begin{array}{l}2.1 \text { Acupuncture vs sham acupunc- } \\
\text { ture }\end{array}$ & 3 & 244 & $\begin{array}{l}\text { Odds Ratio (M-H, Random, } \\
95 \% \mathrm{Cl})\end{array}$ & $0.67[0.40,1.12]$ \\
\hline 2.2 Acupuncture vs open control & 6 & 1192 & $\begin{array}{l}\text { Odds Ratio (M-H, Random, } \\
95 \% \mathrm{Cl})\end{array}$ & $0.62[0.42,0.93]$ \\
\hline $\begin{array}{l}3 \text { Death or institutional care at end } \\
\text { of follow-up }\end{array}$ & 5 & 1120 & $\begin{array}{l}\text { Odds Ratio (M-H, Random, } \\
95 \% \mathrm{Cl})\end{array}$ & $0.78[0.54,1.12]$ \\
\hline $\begin{array}{l}3.1 \text { Acupuncture vs sham acupunc- } \\
\text { ture }\end{array}$ & 2 & 145 & $\begin{array}{l}\text { Odds Ratio (M-H, Random, } \\
95 \% \mathrm{Cl})\end{array}$ & $0.47[0.23,0.96]$ \\
\hline 3.2 Acupuncture vs open control & 4 & 975 & $\begin{array}{l}\text { Odds Ratio (M-H, Random, } \\
95 \% \mathrm{Cl})\end{array}$ & $0.93[0.61,1.42]$ \\
\hline $\begin{array}{l}4 \text { Change in global neurological } \\
\text { deficit score at end of treatment pe- } \\
\text { riod }\end{array}$ & 12 & 1086 & $\begin{array}{l}\text { Std. Mean Difference (IV, Ran- } \\
\text { dom, } 95 \% \mathrm{CI} \text { ) }\end{array}$ & $0.84[0.36,1.32]$ \\
\hline
\end{tabular}




\begin{tabular}{|c|c|c|c|c|}
\hline Outcome or subgroup title & No. of studies & $\begin{array}{l}\text { No. of partici- } \\
\text { pants }\end{array}$ & Statistical method & Effect size \\
\hline $\begin{array}{l}\text { 4.1 Acupuncture vs sham acupunc- } \\
\text { ture }\end{array}$ & 1 & 53 & $\begin{array}{l}\text { Std. Mean Difference (IV, Ran- } \\
\text { dom, } 95 \% \mathrm{CI} \text { ) }\end{array}$ & $0.01[-0.55,0.57]$ \\
\hline 4.2 Acupuncture vs open control & 12 & 1033 & $\begin{array}{l}\text { Std. Mean Difference (IV, Ran- } \\
\text { dom, } 95 \% \mathrm{CI} \text { ) }\end{array}$ & $0.91[0.41,1.41]$ \\
\hline $\begin{array}{l}5 \text { Motor function at end of acupunc- } \\
\text { ture treatment period }\end{array}$ & 11 & 895 & $\begin{array}{l}\text { Std. Mean Difference (IV, Ran- } \\
\text { dom, } 95 \% \mathrm{Cl} \text { ) }\end{array}$ & $1.08[0.45,1.71]$ \\
\hline $\begin{array}{l}5.1 \text { Acupuncture vs sham acupunc- } \\
\text { ture }\end{array}$ & 3 & 202 & $\begin{array}{l}\text { Std. Mean Difference (IV, Ran- } \\
\text { dom, } 95 \% \mathrm{CI} \text { ) }\end{array}$ & $-0.10[-0.38,0.17]$ \\
\hline 5.2 Acupuncture vs open control & 8 & 693 & $\begin{array}{l}\text { Std. Mean Difference (IV, Ran- } \\
\text { dom, } 95 \% \mathrm{CI} \text { ) }\end{array}$ & $1.52[0.70,2.34]$ \\
\hline $\begin{array}{l}6 \text { Motor function at end of follow-up } \\
\text { (>3 months) }\end{array}$ & 3 & 186 & $\begin{array}{l}\text { Std. Mean Difference (IV, Ran- } \\
\text { dom, } 95 \% \mathrm{Cl} \text { ) }\end{array}$ & $0.08[-0.21,0.37]$ \\
\hline $\begin{array}{l}\text { 6.1 Acupuncture vs sham acupunc- } \\
\text { ture }\end{array}$ & 2 & 144 & $\begin{array}{l}\text { Std. Mean Difference (IV, Ran- } \\
\text { dom, } 95 \% \mathrm{Cl} \text { ) }\end{array}$ & $-0.02[-0.35,0.31]$ \\
\hline 6.2 Acupuncture vs open control & 1 & 42 & $\begin{array}{l}\text { Std. Mean Difference (IV, Ran- } \\
\text { dom, } 95 \% \mathrm{CI} \text { ) }\end{array}$ & $0.44[-0.18,1.05]$ \\
\hline 7 Death within first 2 weeks & 18 & 1612 & $\begin{array}{l}\text { Odds Ratio (M-H, Random, } \\
95 \% \mathrm{Cl})\end{array}$ & $0.91[0.33,2.55]$ \\
\hline $\begin{array}{l}\text { 7.1 Acupuncture vs sham acupunc- } \\
\text { ture }\end{array}$ & 5 & 378 & $\begin{array}{l}\text { Odds Ratio (M-H, Random, } \\
95 \% \mathrm{Cl})\end{array}$ & $1.20[0.27,5.26]$ \\
\hline 7.2 Acupuncture vs open control & 14 & 1234 & $\begin{array}{l}\text { Odds Ratio (M-H, Random, } \\
95 \% \mathrm{Cl})\end{array}$ & $0.71[0.17,2.96]$ \\
\hline $\begin{array}{l}8 \text { Death during whole follow-up pe- } \\
\text { riod }\end{array}$ & 22 & 2865 & $\begin{array}{l}\text { Odds Ratio (M-H, Random, } \\
95 \% \mathrm{Cl})\end{array}$ & $1.08[0.74,1.58]$ \\
\hline $\begin{array}{l}\text { 8.1 Acupuncture vs sham acupunc- } \\
\text { ture }\end{array}$ & 6 & 668 & $\begin{array}{l}\text { Odds Ratio (M-H, Random, } \\
95 \% \mathrm{Cl})\end{array}$ & $0.90[0.47,1.72]$ \\
\hline 8.2 Acupuncture vs open control & 17 & 2197 & $\begin{array}{l}\text { Odds Ratio (M-H, Random, } \\
95 \% \mathrm{Cl})\end{array}$ & $1.19[0.74,1.91]$ \\
\hline $\begin{array}{l}9 \text { Adverse events during treatment } \\
\text { period }\end{array}$ & 5 & 576 & $\begin{array}{l}\text { Odds Ratio (M-H, Random, } \\
95 \% \mathrm{Cl})\end{array}$ & $0.58[0.29,1.16]$ \\
\hline
\end{tabular}

Analysis 1.1. Comparison 1 Acupuncture versus control, Outcome 1 Death or dependency at end of follow-up.

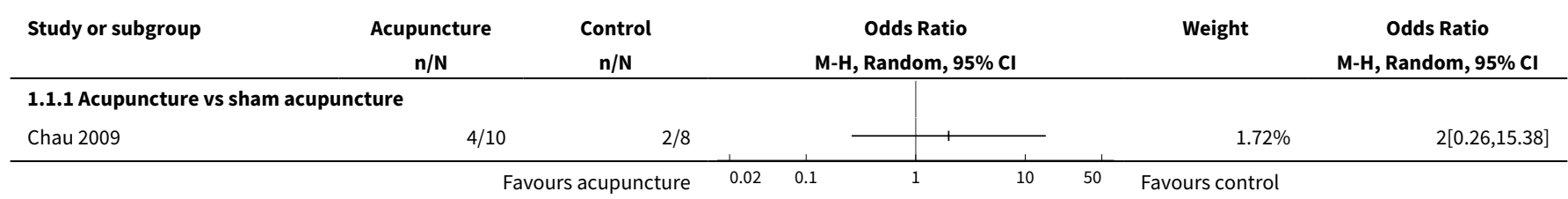




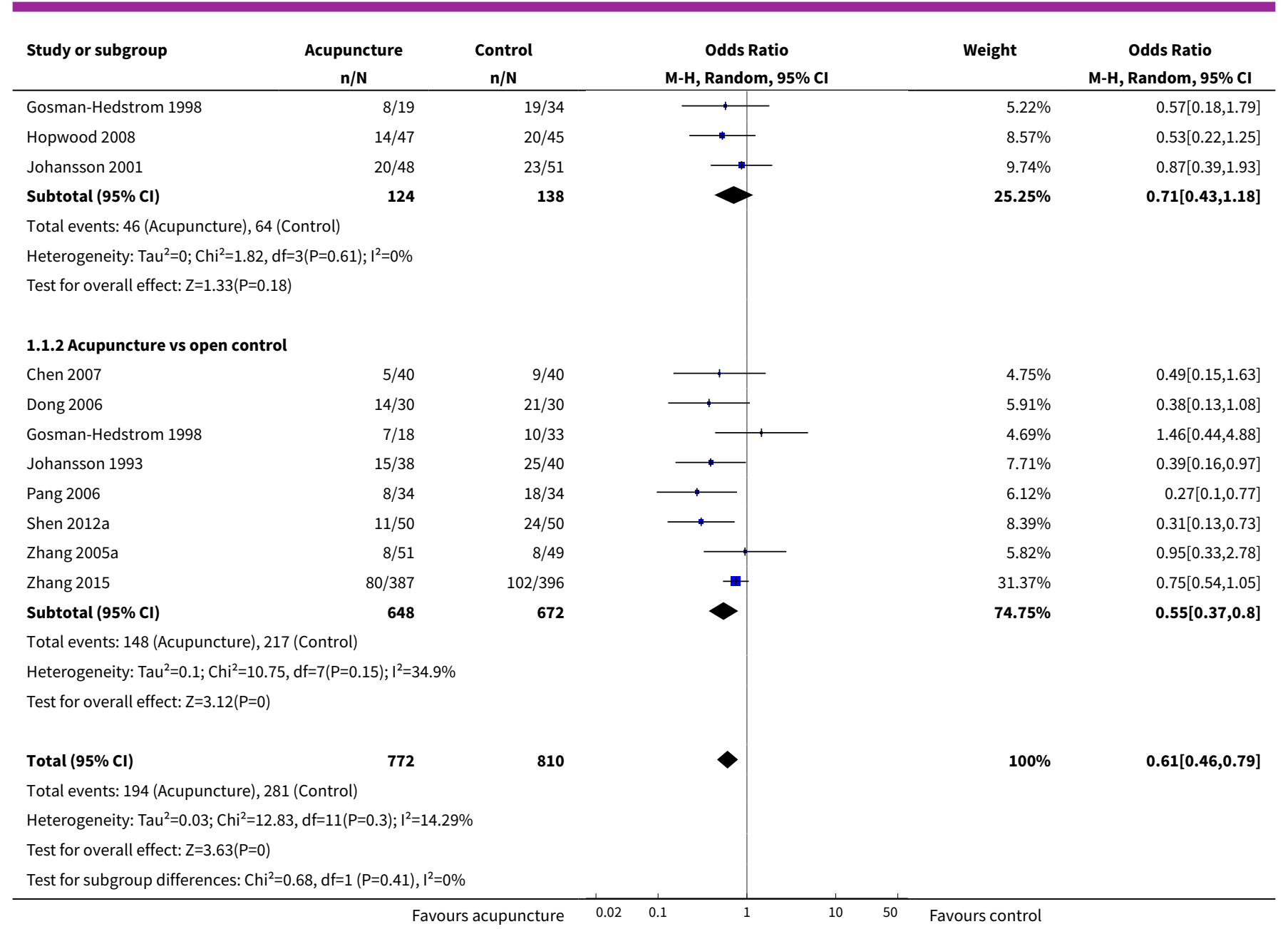

Analysis 1.2. Comparison 1 Acupuncture versus control, Outcome 2 Death or dependency at end of follow-up ( 3 months).

\begin{tabular}{|c|c|c|c|c|c|}
\hline Study or subgroup & $\begin{array}{c}\text { Acupuncture } \\
\mathrm{n} / \mathrm{N}\end{array}$ & $\begin{array}{c}\text { Control } \\
\mathrm{n} / \mathrm{N}\end{array}$ & $\begin{array}{c}\text { Odds Ratio } \\
\text { M-H, Random, } 95 \% \mathrm{Cl}\end{array}$ & Weight & $\begin{array}{c}\text { Odds Ratio } \\
\text { M-H, Random, } 95 \% \mathrm{Cl}\end{array}$ \\
\hline \multicolumn{6}{|c|}{ 1.2.1 Acupuncture vs sham acupuncture } \\
\hline Gosman-Hedstrom 1998 & $8 / 19$ & $19 / 34$ & & $4.44 \%$ & $0.57[0.18,1.79]$ \\
\hline Hopwood 2008 & $14 / 47$ & $20 / 45$ & & $7.76 \%$ & $0.53[0.22,1.25]$ \\
\hline Johansson 2001 & $20 / 48$ & $23 / 51$ & & $9.03 \%$ & $0.87[0.39,1.93]$ \\
\hline Subtotal $(95 \% \mathrm{Cl})$ & 114 & 130 & & $21.23 \%$ & $0.67[0.4,1.12]$ \\
\hline \multicolumn{6}{|c|}{ Heterogeneity: $\mathrm{Tau}^{2}=0 ; \mathrm{Chi}^{2}=0.77, \mathrm{df}=2(\mathrm{P}=0.68) ; \mathrm{I}^{2}=0 \%$} \\
\hline \multicolumn{6}{|c|}{ Test for overall effect: $Z=1.54(P=0.12)$} \\
\hline \multicolumn{6}{|c|}{ 1.2.2 Acupuncture vs open control } \\
\hline Chen 2007 & $5 / 40$ & $9 / 40$ & & $4 \%$ & $0.49[0.15,1.63]$ \\
\hline Gosman-Hedstrom 1998 & $7 / 18$ & $10 / 33$ & & $3.95 \%$ & $1.46[0.44,4.88]$ \\
\hline Shen 2012a & $11 / 50$ & $24 / 50$ & & $7.57 \%$ & $0.31[0.13,0.73]$ \\
\hline Zhang 2005a & $8 / 51$ & $8 / 49$ & & $5 \%$ & $0.95[0.33,2.78]$ \\
\hline
\end{tabular}




\begin{tabular}{|c|c|c|c|c|c|}
\hline Study or subgroup & $\begin{array}{c}\text { Acupuncture } \\
\mathrm{n} / \mathrm{N}\end{array}$ & \multirow{2}{*}{$\begin{array}{l}\text { Control } \\
\text { n/N } \\
102 / 396\end{array}$} & $\begin{array}{c}\text { Odds Ratio } \\
\text { M-H, Random, } 95 \% \mathrm{Cl}\end{array}$ & Weight & \multirow{2}{*}{$\begin{array}{c}\text { Odds Ratio } \\
\text { M-H, Random, 95\% Cl } \\
0.75[0.54,1.05]\end{array}$} \\
\hline Zhang 2015 & $80 / 387$ & & 4 & $51.39 \%$ & \\
\hline Subtotal $(95 \% \mathrm{Cl})$ & 584 & 608 & - & $78.77 \%$ & $0.62[0.42,0.93]$ \\
\hline \multicolumn{6}{|c|}{ Total events: 126 (Acupuncture), 178 (Control) } \\
\hline \multicolumn{6}{|c|}{ Heterogeneity: $\mathrm{Tau}^{2}=0.08 ; \mathrm{Chi}^{2}=7.21, \mathrm{df}=5(\mathrm{P}=0.21) ; \mathrm{I}^{2}=30.68 \%$} \\
\hline \multicolumn{6}{|c|}{ Test for overall effect: $Z=2.29(P=0.02)$} \\
\hline Total $(95 \% \mathrm{Cl})$ & 698 & 738 & - & $100 \%$ & $0.67[0.53,0.85]$ \\
\hline \multicolumn{6}{|c|}{ Total events: 168 (Acupuncture), 240 (Control) } \\
\hline \multicolumn{6}{|c|}{ Heterogeneity: $\mathrm{Tau}^{2}=0 ; \mathrm{Chi}^{2}=7.98, \mathrm{df}=8(\mathrm{P}=0.44) ; \mathrm{I}^{2}=0 \%$} \\
\hline \multicolumn{6}{|c|}{ Test for overall effect: $Z=3.31(P=0)$} \\
\hline Test for subgroup dif & 03, $d f=1(P=0.85)$, & & & & \\
\hline
\end{tabular}

Analysis 1.3. Comparison 1 Acupuncture versus control, Outcome 3 Death or institutional care at end of follow-up.

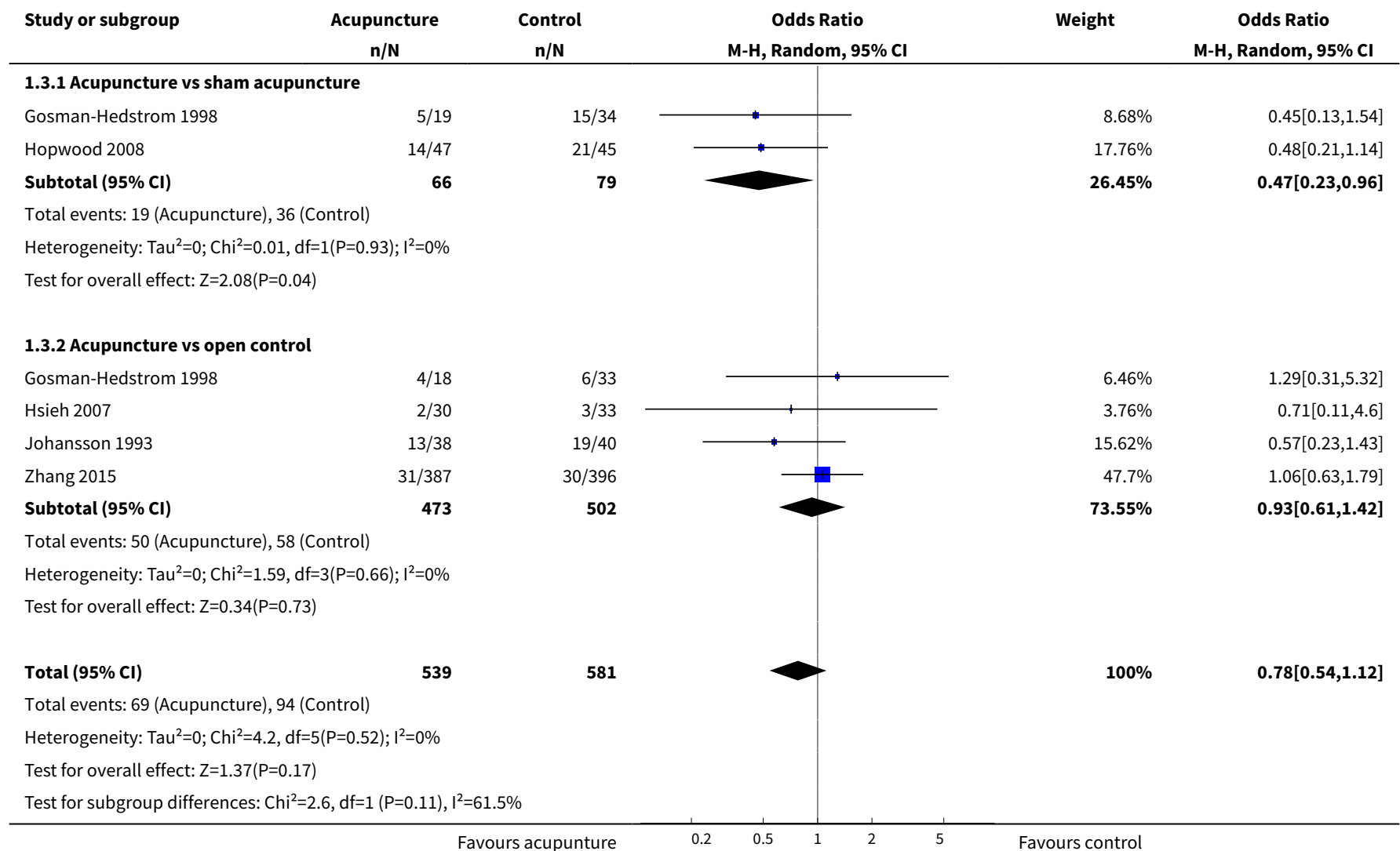


Analysis 1.4. Comparison 1 Acupuncture versus control, Outcome 4 Change in global neurological deficit score at end of treatment period.

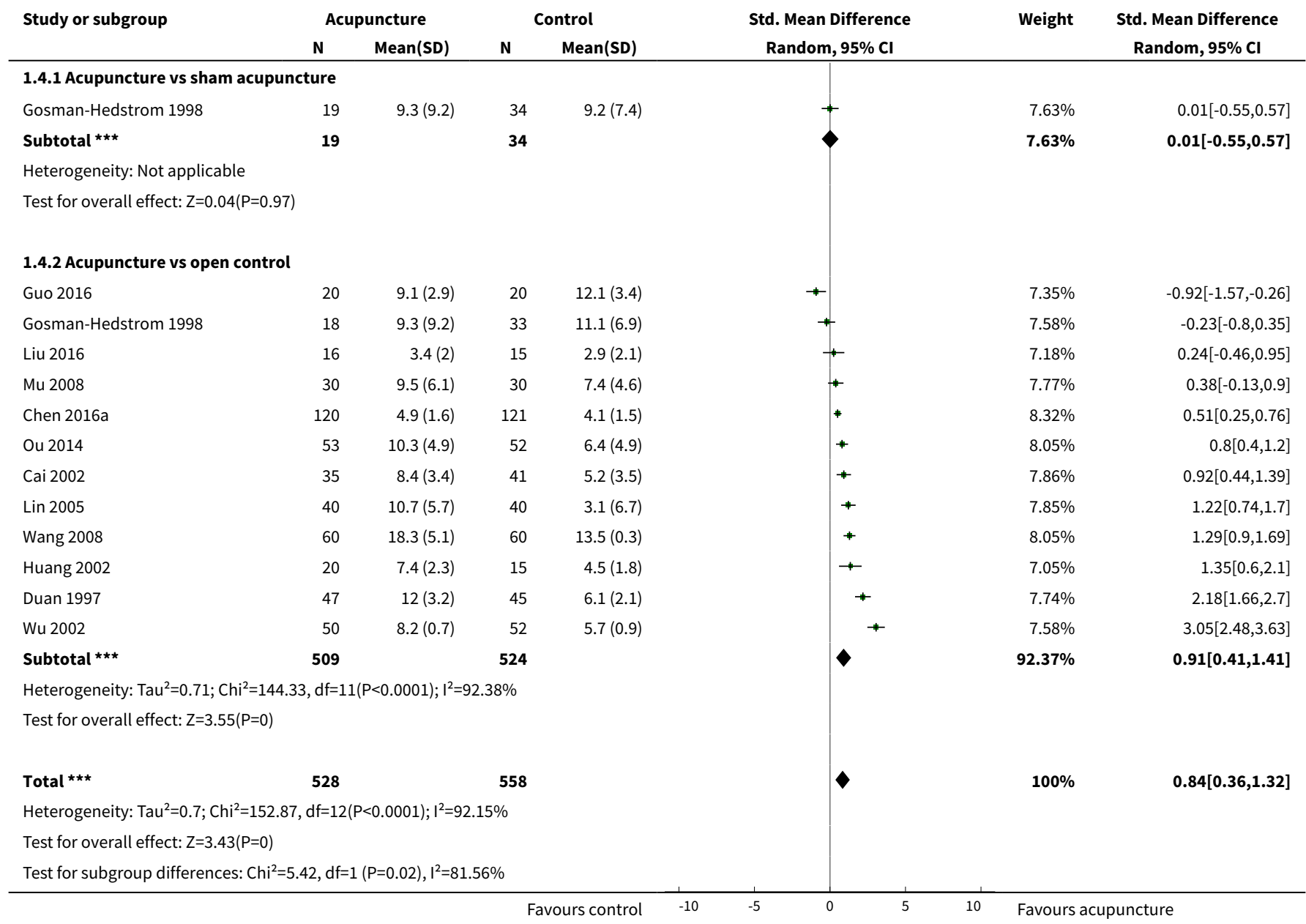

\section{Analysis 1.5. Comparison 1 Acupuncture versus control, Outcome 5 Motor function at end of acupuncture treatment period.}

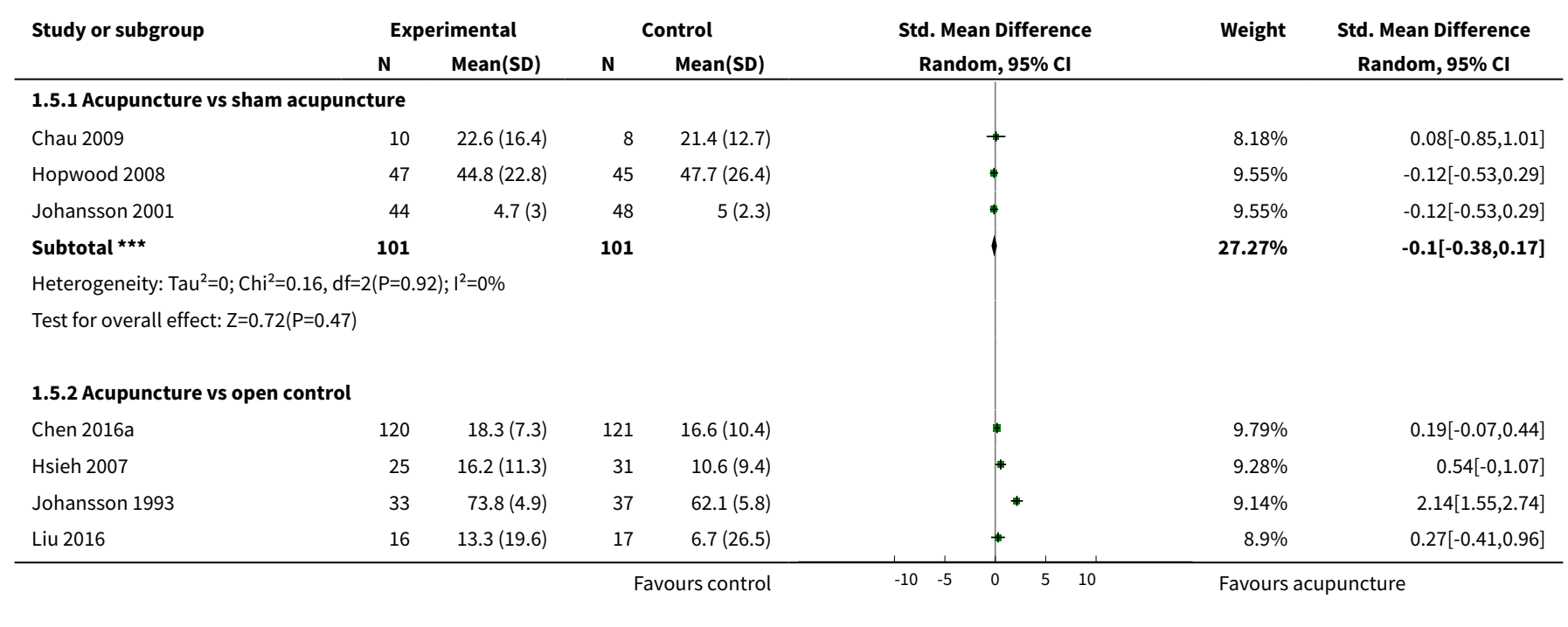




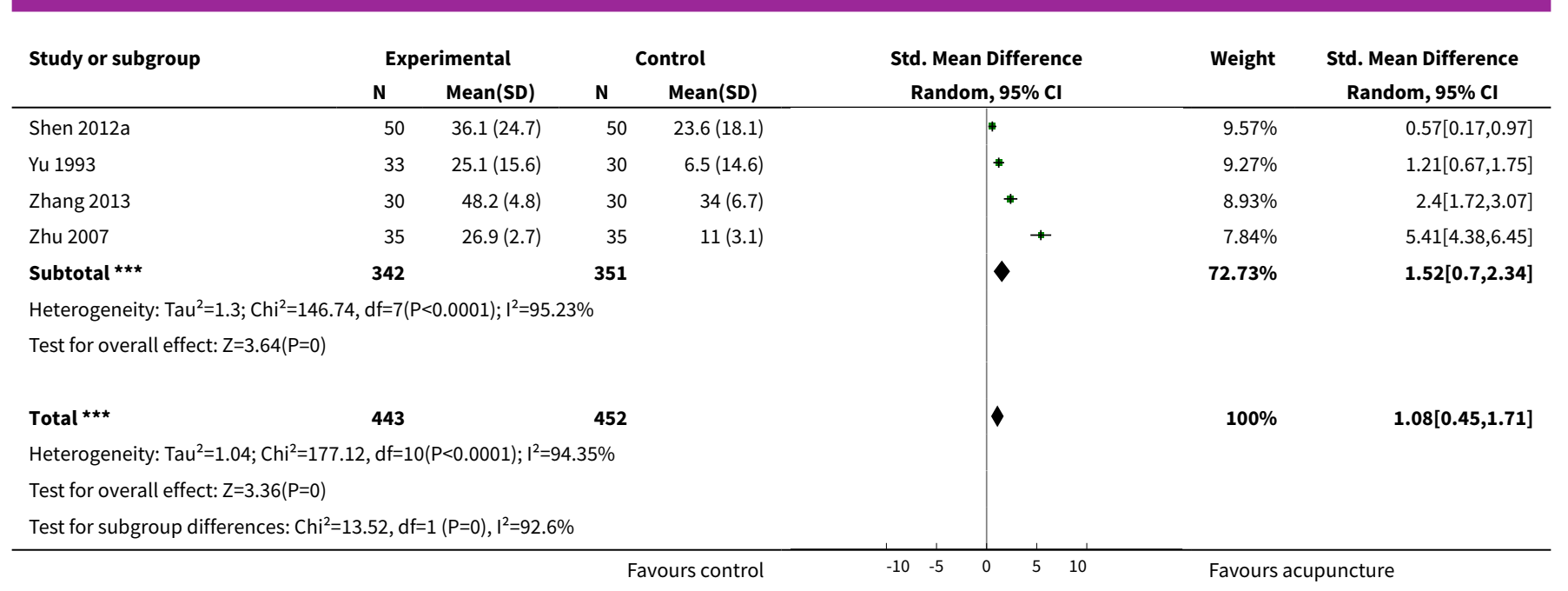

Analysis 1.6. Comparison 1 Acupuncture versus control, Outcome 6 Motor function at end of follow-up (>3 months).

\begin{tabular}{|c|c|c|c|c|c|c|c|}
\hline \multirow[t]{2}{*}{ Study or subgroup } & \multicolumn{2}{|c|}{ Experimental } & \multicolumn{2}{|c|}{ Control } & \multirow{2}{*}{$\begin{array}{c}\text { Std. Mean Difference } \\
\text { Random, } 95 \% \mathrm{Cl}\end{array}$} & \multirow[t]{2}{*}{ Weight } & \multirow{2}{*}{$\begin{array}{c}\text { Std. Mean Difference } \\
\text { Random, } 95 \% \mathrm{Cl}\end{array}$} \\
\hline & $\mathbf{N}$ & Mean(SD) & $\mathbf{N}$ & Mean(SD) & & & \\
\hline \multicolumn{5}{|c|}{ 1.6.1 Acupuncture vs sham acupuncture } & & & \\
\hline Hopwood 2008 & 34 & $69(24.5)$ & 33 & $67.5(26.4)$ & \# & $36.68 \%$ & $0.06[-0.42,0.54]$ \\
\hline Johansson 2001 & 32 & $6(3.1)$ & 45 & $6.3(3.2)$ & 由 & $40.94 \%$ & $-0.09[-0.54,0.37]$ \\
\hline Subtotal $\star \star \star$ & 66 & & 78 & & 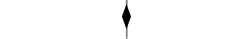 & $77.63 \%$ & $-0.02[-0.35,0.31]$ \\
\hline \multicolumn{8}{|c|}{ Heterogeneity: $\operatorname{Tau}^{2}=0 ; \mathrm{Chi}^{2}=0.19, \mathrm{df}=1(\mathrm{P}=0.66) ;\left.\right|^{2}=0 \%$} \\
\hline \multicolumn{8}{|c|}{ Test for overall effect: $Z=0.11(P=0.91)$} \\
\hline \multicolumn{8}{|c|}{ 1.6.2 Acupuncture vs open control } \\
\hline Hsieh 2007 & 20 & $35.3(25.6)$ & 22 & $25.6(17.8)$ & * & $22.37 \%$ & $0.44[-0.18,1.05]$ \\
\hline Subtotal $\star \star \star$ & 20 & & 22 & & $\checkmark$ & $22.37 \%$ & $0.44[-0.18,1.05]$ \\
\hline \multicolumn{8}{|c|}{ Heterogeneity: Not applicable } \\
\hline \multicolumn{8}{|c|}{ Test for overall effect: $Z=1.39(P=0.16)$} \\
\hline 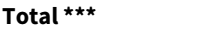 & 86 & & 100 & & 1 & $100 \%$ & $0.08[-0.21,0.37]$ \\
\hline \multicolumn{8}{|c|}{ Heterogeneity: $\mathrm{Tau}^{2}=0 ; \mathrm{Chi}^{2}=1.83, \mathrm{df}=2(\mathrm{P}=0.4) ; \mathrm{I}^{2}=0 \%$} \\
\hline \multicolumn{8}{|c|}{ Test for overall effect: $\mathrm{Z}=0.56(\mathrm{P}=0.58)$} \\
\hline Test for subgroup di & $54, \mathrm{df}=$ & $P=0.2), I^{2}=38$. & & & & & \\
\hline
\end{tabular}

Analysis 1.7. Comparison 1 Acupuncture versus control, Outcome 7 Death within first 2 weeks.

\begin{tabular}{|c|c|c|c|c|c|}
\hline Study or subgroup & $\begin{array}{c}\text { Experimental } \\
n / N\end{array}$ & $\begin{array}{c}\text { Control } \\
n / N\end{array}$ & $\begin{array}{c}\text { Odds Ratio } \\
\text { M-H, Random, } 95 \% \mathrm{Cl}\end{array}$ & Weight & $\begin{array}{c}\text { Odds Ratio } \\
\text { M-H, Random, } 95 \% \mathrm{Cl}\end{array}$ \\
\hline \multicolumn{6}{|c|}{ 1.7.1 Acupuncture vs sham acupuncture } \\
\hline Chau 2009 & $0 / 10$ & $0 / 8$ & & & Not estimable \\
\hline Gosman-Hedstrom 1998 & $1 / 19$ & $0 / 34$ & & $10.05 \%$ & $5.59[0.22,144.3]$ \\
\hline Hopwood 2008 & $0 / 47$ & $1 / 45$ & & $10.2 \%$ & $0.31[0.01,7.87]$ \\
\hline Johansson 2001 & $0 / 48$ & $1 / 51$ & & $10.21 \%$ & $0.35[0.01,8.73]$ \\
\hline
\end{tabular}




\begin{tabular}{|c|c|c|c|c|c|}
\hline Study or subgroup & $\begin{array}{c}\text { Experimental } \\
\mathrm{n} / \mathrm{N}\end{array}$ & $\begin{array}{c}\text { Control } \\
n / N\end{array}$ & $\begin{array}{c}\text { Odds Ratio } \\
\text { M-H, Random, } 95 \% \mathrm{CI}\end{array}$ & Weight & $\begin{array}{c}\text { Odds Ratio } \\
\text { M-H, Random, } 95 \% \mathrm{Cl}\end{array}$ \\
\hline Subtotal $(95 \% \mathrm{Cl})$ & 180 & 198 & & $48.46 \%$ & $1.2[0.27,5.26]$ \\
\hline \multicolumn{6}{|c|}{ Total events: 3 (Experimental), 3 (Control) } \\
\hline \multicolumn{6}{|c|}{ Heterogeneity: $\operatorname{Tau}^{2}=0 ; \mathrm{Chi}^{2}=2.33, \mathrm{df}=3(\mathrm{P}=0.51) ; \mathrm{I}^{2}=0 \%$} \\
\hline \multicolumn{6}{|c|}{ Test for overall effect: $Z=0.24(P=0.81)$} \\
\hline \multicolumn{6}{|c|}{ 1.7.2 Acupuncture vs open control } \\
\hline Cai 2002 & $0 / 35$ & $0 / 41$ & & & Not estimable \\
\hline Chen 1997 & $2 / 95$ & $2 / 72$ & & $26.96 \%$ & $0.75[0.1,5.48]$ \\
\hline Dong 2006 & $0 / 30$ & $0 / 30$ & & & Not estimable \\
\hline Gosman-Hedstrom 1998 & $1 / 18$ & $1 / 33$ & & $13.22 \%$ & $1.88[0.11,32.01]$ \\
\hline Guo 2016 & $0 / 20$ & $0 / 20$ & & & Not estimable \\
\hline Jin 1999 & $0 / 60$ & $2 / 60$ & & $11.36 \%$ & $0.19[0.01,4.11]$ \\
\hline Johansson 1993 & $0 / 38$ & $0 / 40$ & & & Not estimable \\
\hline Lin 2005 & $0 / 40$ & $0 / 40$ & & & Not estimable \\
\hline Ou 2014 & $0 / 53$ & $0 / 52$ & & & Not estimable \\
\hline Pang 2006 & $0 / 34$ & $0 / 34$ & & & Not estimable \\
\hline Shen 2012a & $0 / 50$ & $0 / 50$ & & & Not estimable \\
\hline Sze 2002 & $0 / 53$ & $0 / 53$ & & & Not estimable \\
\hline Wang 2008 & $0 / 60$ & $0 / 60$ & & & Not estimable \\
\hline Yu 1993 & $0 / 33$ & $0 / 30$ & & & Not estimable \\
\hline Subtotal $(95 \% \mathrm{Cl})$ & 619 & 615 & & $51.54 \%$ & $0.71[0.17,2.96]$ \\
\hline \multicolumn{6}{|c|}{ Total events: 3 (Experimental), 5 (Control) } \\
\hline \multicolumn{6}{|c|}{ Heterogeneity: $\mathrm{Tau}^{2}=0 ; \mathrm{Chi}^{2}=1.17, \mathrm{df}=2(\mathrm{P}=0.56) ; \mathrm{I}^{2}=0 \%$} \\
\hline \multicolumn{6}{|c|}{ Test for overall effect: $\mathrm{Z}=0.48(\mathrm{P}=0.63)$} \\
\hline Total $(95 \% \mathrm{Cl})$ & 799 & 813 & & $100 \%$ & $0.91[0.33,2.55]$ \\
\hline \multicolumn{6}{|c|}{ Total events: 6 (Experimental), 8 (Control) } \\
\hline \multicolumn{6}{|c|}{ Heterogeneity: $\mathrm{Tau}^{2}=0 ; \mathrm{Chi}^{2}=3.75, \mathrm{df}=6(\mathrm{P}=0.71) ; \mathrm{I}^{2}=0 \%$} \\
\hline \multicolumn{6}{|c|}{ Test for overall effect: $\mathrm{Z}=0.18(\mathrm{P}=0.86)$} \\
\hline \multicolumn{6}{|c|}{ Test for subgroup differences: $\mathrm{Chi}^{2}=0.25, \mathrm{df}=1(\mathrm{P}=0.62), \mathrm{I}^{2}=0 \%$} \\
\hline
\end{tabular}

\section{Analysis 1.8. Comparison 1 Acupuncture versus control, Outcome 8 Death during whole follow-up period.}

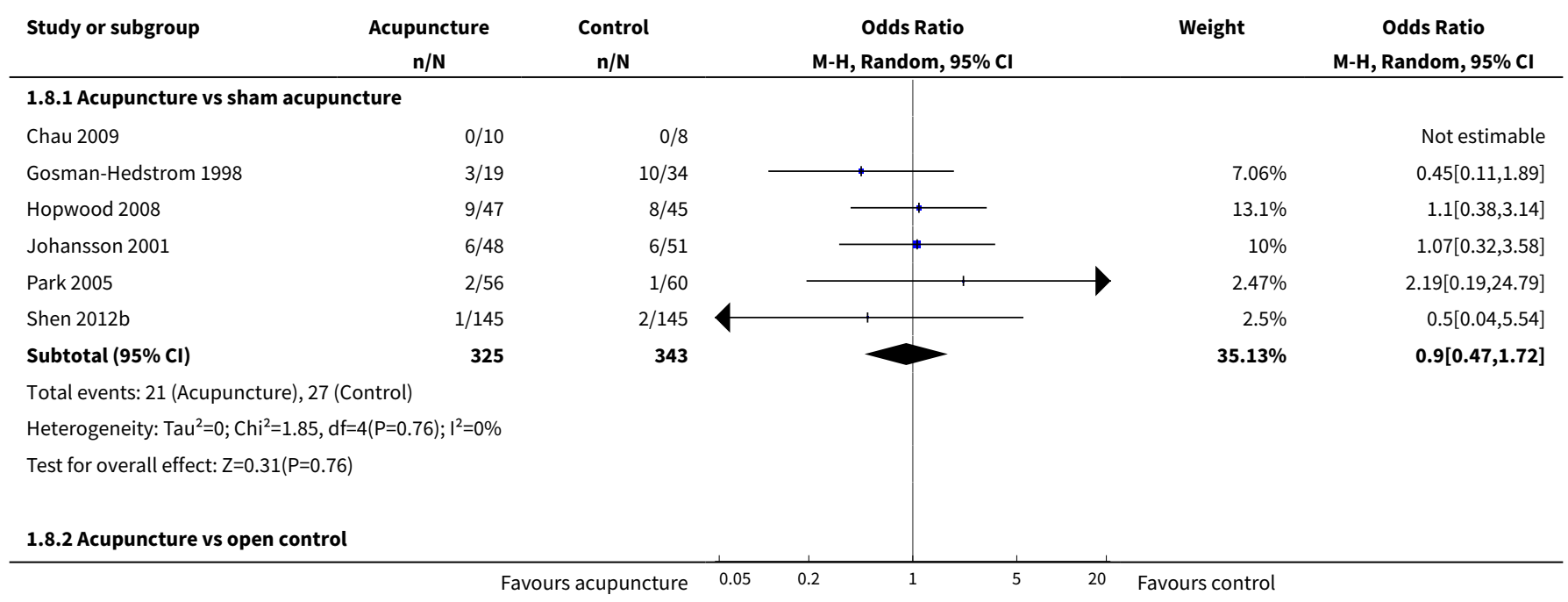




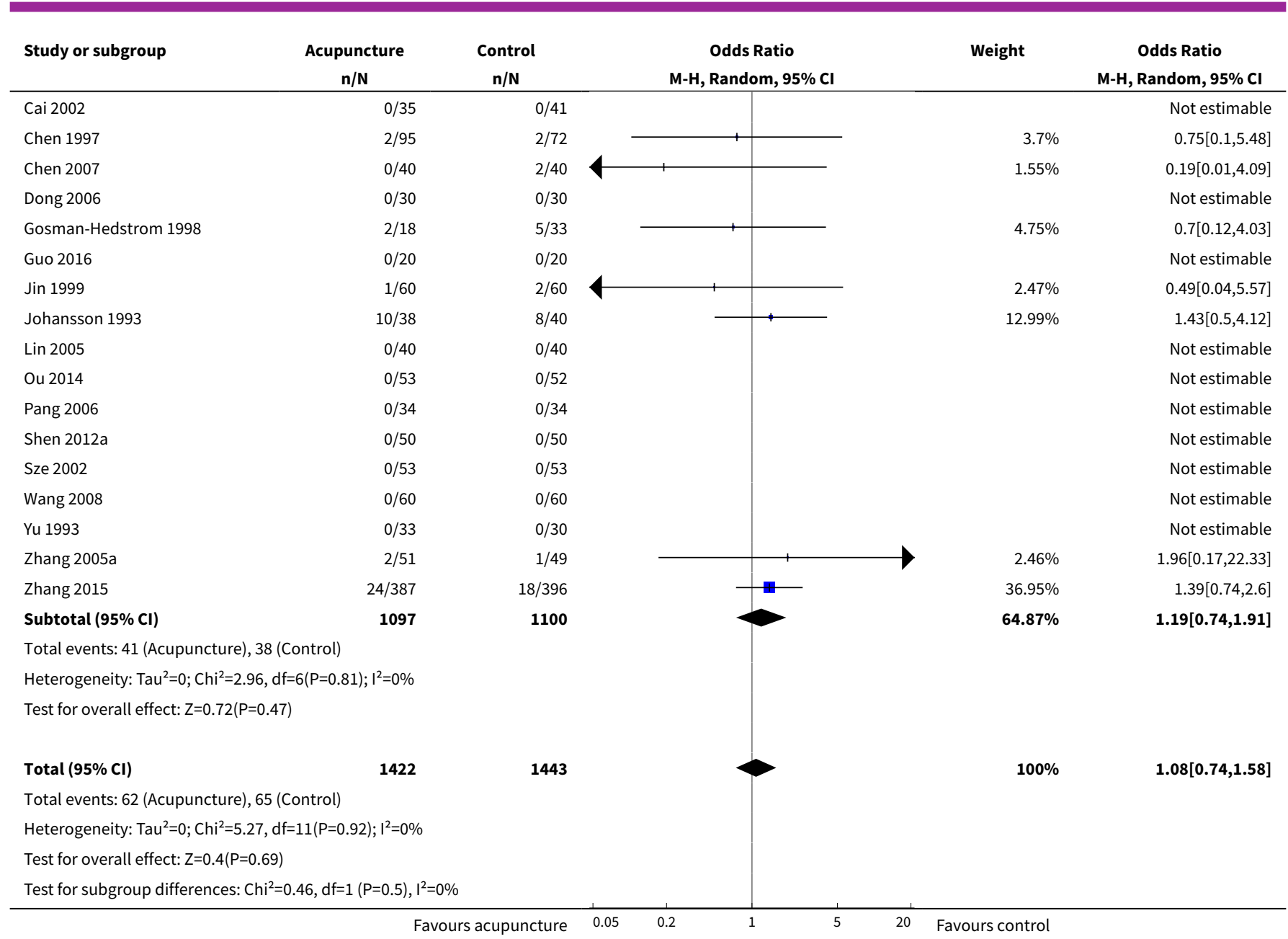

Analysis 1.9. Comparison 1 Acupuncture versus control, Outcome 9 Adverse events during treatment period.

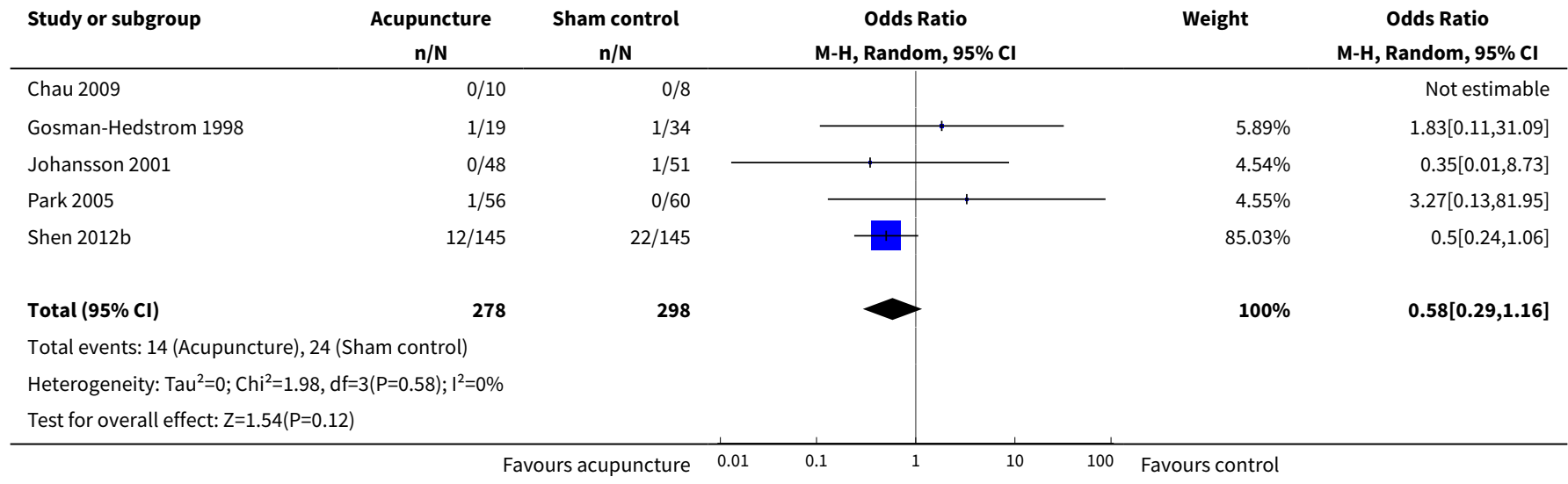


Comparison 2. Ischemic stroke versus hemorrhagic stroke

\begin{tabular}{lllll}
\hline Outcome or subgroup title & No. of studies & $\begin{array}{l}\text { No. of partici- } \\
\text { pants }\end{array}$ & Statistical method & Effect size \\
\hline $\begin{array}{l}\text { 1 Death or dependency at end of fol- } \\
\text { low-up }\end{array}$ & 6 & 1094 & $\begin{array}{l}\text { Odds Ratio (M-H, Random, } \\
95 \% \mathrm{Cl})\end{array}$ & $0.71[0.54,0.94]$ \\
\hline $\begin{array}{l}\text { 1.1 Death or dependency in hemor- } \\
\text { rhagic stroke }\end{array}$ & 1 & 60 & $\begin{array}{l}\text { Odds Ratio (M-H, Random, } \\
95 \% \mathrm{Cl})\end{array}$ & $0.38[0.13,1.08]$ \\
\hline $\begin{array}{l}\text { 1.2 Death or dependency in ischemic } \\
\text { stroke }\end{array}$ & 5 & 1034 & $\begin{array}{l}\text { Odds Ratio (M-H, Random, } \\
95 \% \mathrm{Cl})\end{array}$ & $0.75[0.56,1.00]$ \\
\hline
\end{tabular}

\section{Analysis 2.1. Comparison 2 Ischemic stroke versus hemorrhagic} stroke, Outcome 1 Death or dependency at end of follow-up.

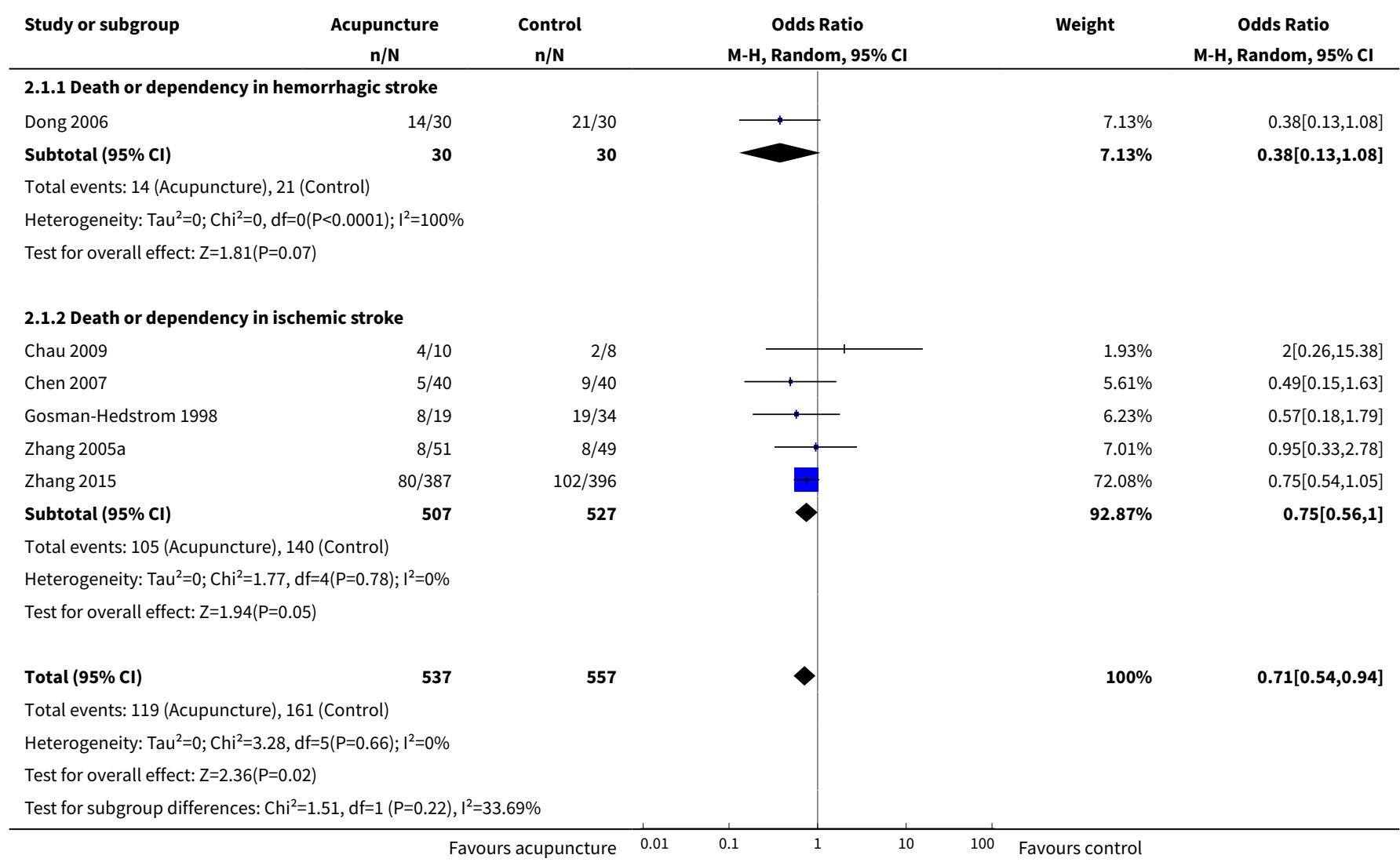

\section{APPENDICES}

\section{Appendix 1. Search strategy for CENTRAL}

1 exp cerebrovascular disorders/

2 (stroke\$ or poststroke\$ or cva\$).tw.

3 (cerebrovascular or cerebral vascular).tw.

4 (cerebral or cerebellar or brainstem or vertebrobasilar).tw. 
5 (infarct\$ or isch?emi\$ or thrombo\$ or apoplexy or emboli\$).tw.

64 and 5

7 (cerebral or intracerebral or intracranial or parenchymal).tw.

8 (brain or intraventricular or brainstem or cerebellar).tw.

9 (infratentorial or supratentorial or subarachnoid).tw.

107 or 8 or 9

11 (haemorrhage or haemorrhage or hematoma or hematoma).tw.

12 (bleeding or aneurysm).tw.

1311 or 12

1410 and 13

15 thrombo\$.tw.

16 (intracranial or sinus or (venous adj5 sinus\$) or (sagittal adj5 venous) or (sagittal adj5 vein)).tw.

1715 and 16

181 or 2 or 3 or 6 or 14 or 17

19 acupuncture/

20 exp acupuncture therapy/

21 electroacupuncture/

22 meridians/

23 acupuncture points/

24 acupuncture $\$$.tw.

25 (electroacupuncture or electro-acupuncture).tw.

26 acupoints.tw.

27 ((meridian or non-meridian or trigger) adj10 point\$).tw.

28 or $/ 19-27$

2918 and 28

\section{Appendix 2. Search strategy for MEDLINE}

1 exp cerebrovascular disorders/

2 (stroke\$ or poststroke\$ or cva\$).tw.

3 (cerebrovascular\$ or cerebral vascular).tw.

4 (cerebral or cerebellar or brainstem or vertebrobasilar).tw.

5 (infarct\$ or isch?emi\$ or thrombo\$ or apoplexy or emboli\$).tw.

64 and 5

7 (cerebral or intracerebral or intracranial or parenchymal).tw.

8 (brain or intraventricular or brainstem or cerebellar).tw.

9 (infratentorial or supratentorial or subarachnoid).tw.

107 or 8 or 9

11 (haemorrhage or haemorrhage or hematoma or hematoma).tw.

12 (bleeding or aneurysm).tw.

1311 or 12

1410 and 13

15 thrombo\$.tw.

16 (intracranial or sinus or (venous adj5 sinus\$) or (sagittal adj5 venous) or (sagittal adj5 vein)).tw.

1715 and 16

181 or 2 or 3 or 6 or 14 or 17

19 acupuncture/

20 exp acupuncture therapy/

21 electroacupuncture/

22 meridians/

23 acupuncture points/

24 acupuncture\$.tw.

25 (electroacupuncture or electro-acupuncture).tw.

26 acupoints.tw.

27 ((meridian or non-meridian or trigger) adj10 point\$).tw.

28 or/19-27

2918 and 28

\section{Appendix 3. Search strategy for Embase}

1 exp cerebrovascular disease/

2 (stroke\$ or poststroke\$ or cva\$).tw.

3 (cerebrovascular or cerebral vascular).tw. 
4 (cerebral or cerebellar or brainstem or vertebrobasilar).tw.

5 (infarct\$ or isch?emi\$ or thrombo\$ or apoplexy or emboli\$).tw.

64 and 5

7 (cerebral or intracerebral or intracranial or parenchymal).tw.

8 (brain or intraventricular or brainstem or cerebellar).tw.

9 (infratentorial or supratentorial).tw.

107 or 8 or 9

11 (haemorrhage or haemorrhage or hematoma or hematoma).tw.

1210 and 11

131 or 2 or 3 or 6 or 12

14 exp acupuncture/

15 acupunctur\$.tw.

16 (electroacupuncture or electro-acupuncture).tw.

17 acupoint\$.tw.

18 ((meridian or non-meridian or trigger) adj10 point\$).tw.

19 or/14-18

2013 and 19

\section{Appendix 4. Search strategy for CINAHL}

S1 -(MH "Cerebrovascular Disorders") OR (MH "Basal Ganglia Cerebrovascular Disease+") OR (MH "Carotid Artery Diseases+") OR (MH "Cerebral Ischemia+") OR (MH "Cerebral Vasospasm") OR (MH "Intracranial Arterial Diseases+") OR (MH "Intracranial Embolism and Thrombosis") OR (MH "Intracranial Hemorrhage+") OR (MH "Stroke") OR (MH "Vertebral Artery Dissections")

\section{S2 -(MH "Stroke Patients") OR (MH "Stroke Units")}

S3 - TI ( stroke* or poststroke or apoplex* or cerebral vasc* or brain vasc* or cerebrovasc* or cva* or SAH ) or AB ( stroke* or poststroke or apoplex* or cerebral vasc ${ }^{\star}$ or brain vasc ${ }^{\star}$ or cerebrovasc ${ }^{\star}$ or $\mathrm{cva}^{\star}$ or SAH )

S4 - TI ( brain or cerebr* or cerebell* or intracran* or intracerebral) or AB ( brain or cerebr* or cerebell ${ }^{\star}$ or intracran* or intracerebral)

S5 -TI ( ischemi ${ }^{\star}$ or ischaemi ${ }^{\star}$ or infarct* or thrombo* or emboli* or occlus ${ }^{\star}$ ) or AB (ischemi ${ }^{\star}$ or ischaemi ${ }^{\star}$ or infarct $^{\star}$ or thrombo* or emboli ${ }^{\star}$ or occlus $)$

\section{S6 -S4 and S5}

S7 -TI ( brain* or cerebr ${ }^{\star}$ or cerebell ${ }^{\star}$ or intracerebral or intracran* or subarachnoid ) or AB ( brain* or cerebr* or cerebell* or intracerebral or intracran* or subarachnoid)

S8 - TI ( haemorrhage* or hemorrhage* or haematoma* or hematoma* or bleed ${ }^{\star}$ ) or AB ( haemorrhage* or hemorrhage* or haematoma* or hematoma* or bleed*)

S9 -S7 and S8

\section{S10 -S1 OR S2 OR S3 OR S6 OR S9}

S11 -(MH "Acupuncture") OR (MH "Acupuncture Analgesia") OR (MH "Acupuncture Anesthesia") OR (MH "Acupuncture, Ear") OR (MH "Electroacupuncture") OR (MH "Meridians") OR (MH "Acupuncture Points") OR (MH "Acupuncturists") OR (MH "Trigger Point")

S12 - TI (acupuncture* or electroacupuncture or electro-acupuncture or acupoint* or meridians or needling) OR AB (acupuncture ${ }^{\star}$ or electroacupuncture or electro-acupuncture or acupoint* or meridians or needling)

$\mathrm{S} 13-\mathrm{TI}$ ((meridian or non-meridian or trigger) N10 point $\left.{ }^{\star}\right)$ or AB ((meridian or non-meridian or trigger) N10 point $\left.{ }^{\star}\right)$

\section{S14 -S11 OR S12 OR S13}

\section{S15 -S10 AND S14}

\section{Appendix 5. Search strategy for AMED}

1. cerebrovascular disorders/ or cerebral hemorrhage/ or cerebral infarction/or cerebral ischemia/ or cerebrovascular accident/ or stroke/

2. (stroke or poststroke or post-stroke or cerebrovasc\$ or brain vasc\$ or cerebral vasc\$ or cva\$ or apoplex\$ or SAH).tw.

3. ((brain\$ or cerebr\$ or cerebell\$ or intracran\$ or intracerebral) adj5 (isch?emi\$ or infarct\$ or thrombo\$ or emboli\$ or occlus\$)).tw. 
4. ((brain\$ or cerebr\$ or cerebell\$ or intracerebral or intracranial or subarachnoid) adj5 (haemorrhage\$ or hemorrhage\$ or haematoma\$ or hematoma or bleed\$)).tw.

5. or/1-4

6. acupuncture/ or acupuncture therapy/ or acupoints/or neiguan/ or acupuncture analgesia/ or ear acupuncture/ or electroacupuncture/ or meridians/ or needling/ or scalp acupuncture/

7. (acupuncture $\$$ or electroacupuncture or electro-acupuncture or acupoint $\$$ or meridians or needling).tw.

8. ((meridian or non-meridian or trigger) adj10 point\$).tw.

9. 6 or 7 or 8

10.5 and 9

Appendix 6. Search terms for the Chinese Clinical Trial Registry

English:

Target disease: acute stroke or acute ischemic stroke or acute intracerebral hemorrahge

Intervention: acupuncture

Chinese:

研究疾病名称：急性脑卒中

干预措施：针刺

Appendix 7. Search strategy for the WHO International Trials Registry Platform

acupuncture and acute stroke

Appendix 8. Search strategy for Clinicaltrials.gov

acupuncture and acute stroke

WHAT' S NEW

\begin{tabular}{lll}
\hline Date & Event & Description \\
\hline 28 December 2017 & Amended & $\begin{array}{l}\text { The structure and content of this review have been extensive- } \\
\text { ly revised in line with feedback from the Cochrane Stroke Group } \\
\text { and the Cochrane Editorial Unit. Comparisons were restruc- } \\
\text { tured as (1) acupuncture vs any control (open control or sham } \\
\text { acupuncture), and (2) acupuncture vs sham acupuncture. }\end{array}$ \\
\end{tabular}

21 February $2017 \quad$ New citation required and conclusions

This updated review extends the safety results for acupuncture have changed in acute stroke and indicates that acupuncture may improve activities of daily living.

21 February $2017 \quad$ New search has been performed We have included in this update 20 new trials with 2780 partic-
ipants, bringing the total number of included studies to 33 and
included participants to 3946 . The findings presented in this up-
dated review show that acupuncture could be used for treat-
ment of patients with acute stroke, but this remains to be con-
firmed by large sample sizes and high-quality trials, whereas re-
sults of the previous review did not support the routine use of
acupuncture for people with acute stroke. 


\section{CONTRIBUTIONS OF AUTHORS}

Shihong Zhang and Ming Liu designed the protocol and the review. Shihong Zhang resolved disagreements about data collection and made critical suggestions on the manuscript. Mangmang Xu and Dan Li searched databases and extracted data. Mangmang Xu drafted this manuscript.

\section{DECLARATIONS OF INTEREST}

Mangmang Xu: none known.

Dan Li: none known.

Shihong Zhang: none known.

\section{SOURCES OF SUPPORT}

\section{Internal sources}

- No sources of support supplied

\section{External sources}

- Key Research and Development Program, Science \& Technology Department of Sichuan Province (Grant No. 2017SZ0007), China.

\section{DIFFERENCES BETWEEN PROTOCOLANDREVIEW}

The previous version of this review included in the analysis truly unconfounded controlled clinical trials or quasi-randomized trials, whereas only truly unconfounded controlled clinical trials were eligible for inclusion in this updated review.

In the protocol, we planned to use Embase (1980 to the search date) and MEDLINE (1966 to the search date). However, in the review, we used Embase Ovid (1974 to the search date) and MEDLINE Ovid (1946 to the search date), according to the Library of Sichuan University.

Mangmang Xu and Dan Li contributed equally to finishing this updated review and were co-first authors.

Extensive revision of the structure and content of the review in December 2017 was in line with feedback from the Cochrane Stroke Group and the Cochrane Editorial Unit. Comparisons were restructured as (1) acupuncture versus any control (open control or sham acupuncture), and (2) acupuncture versus sham acupuncture.

\section{IN DEX TERMS}

\section{Medical Subject Headings (MeSH)}

${ }^{\star}$ Acupuncture Therapy; Acute Disease; Randomized Controlled Trials as Topic; Stroke [ ${ }^{\star}$ therapy]

\section{MeSH check words}

Humans 